Tricia Michelle Dumais

B.A. (Honours), Early Childhood Education

Ryerson University, Toronto, ON, 2007

A Major Research Paper

Presented to Ryerson University

In partial fulfillment of the

requirements for the degree of

Master of Arts

In the Program of

Early Childhood Studies

Toronto, Ontario, Canada, 2009

(C) Tricia Dumais 2009 


\section{Author's Declaration}

I hereby declare that I am the sole author of this major research paper.

I authorize Ryerson University to lend this paper to other institutions or individuals for the purpose of scholarly research.

Tricia Michelle Dumais

I further authorize Ryerson University to reproduce this paper by photocopying or by other means, in total or in part, at the request of other institutions or individuals for the purpose of scholarly research.

Tricia Michelle Dumais 


\title{
CHILDREN'S LITERATURE
}

(C) Tricia Dumais 2009

Master of Arts

Early Childhood Studies

Ryerson University

\begin{abstract}
Diversity is ignored in many early childhood education settings, especially sexual diversity. The purpose of this study is to determine if children's literature in early childhood education settings represents diversity. Because identity is interconnected, this study includes an exploration of individual aspects of identity such as gender, sexuality, race, class, age, body size and ability. One hundred and nine books from four childcare classrooms were analyzed to investigate the representation of diversity in children's literature. A qualitative queer critique of two of the titles from this study supplemented the compelling yet inadequate findings of the quantitative research. Results showed that beyond moderate representation of racial diversity, the literature examined failed to represent significant diversity of sexuality, class, age, body size, and ability. Through the analysis of children's books it was found that oppression exists in the form of omission. Research from supplementary queer critiques of two titles showed that each book is heteronormative in nature and that one of the books may be deemed homotolerant as it positioned heterosexuality as 'normal,' represented sexuality as private, failed to celebrate difference, and failed to challenge essentialism. The findings of this study may be significant for initiating a dialogue among early childhood professionals to promote a celebration of difference.
\end{abstract}

Keywords: heteronormativity; diversity; queer theory; representation; identity 


\section{Acknowledgement}

The journey of academic growth that has accompanied this research process has been rewarding and could not have been accomplished without the support of many.

I would like to thank my supervisor Dr. Rachel Langford for her patience and support. I am grateful for her shared enthusiasm and reminders of the importance of my work that propelled me through the stages of this research project from conception to the final draft.

I would also like to thank Dr. David Ruffolo for his valuable contributions that challenged me to dig deeper. Thank you also to Dr. Judith Bernhard for her positive and constructive feedback

To the supervisors and early childhood professionals who allowed me access to their bookshelves and personal collection of books, thank you for opening your classes to me.

In particular, I'd like to thank my mother whose strength and pride led me to believe that I can and whose kindness led me to do anti-oppression work. Thank you also to my sisters Carrie and Mandy who have been my optimistic cheerleading section since the beginning.

Most importantly, I'd like to express my deepest gratitude to Felix Munger who planted the seed for this stimulating journey. His steadfast support, unwavering confidence, and tenacious encouragement have made an enormous contribution to my work- thank you! 


\section{Table of Contents}

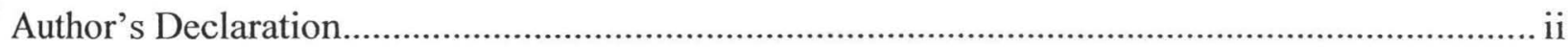

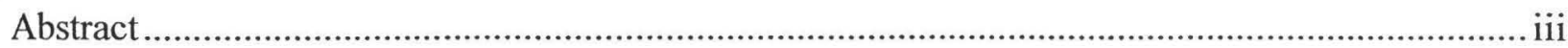

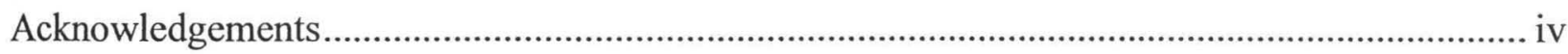

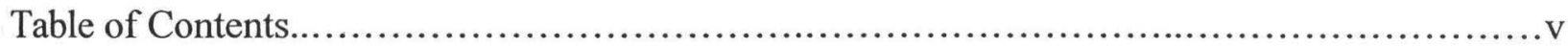

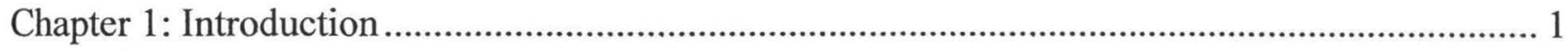

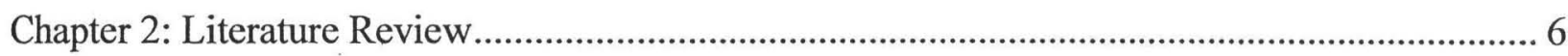

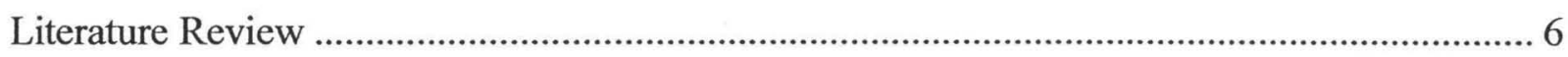

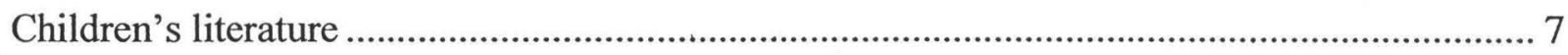

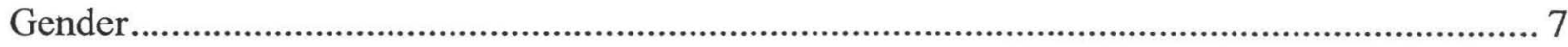

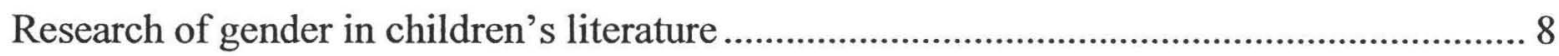

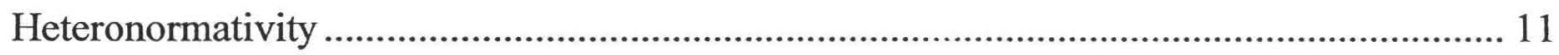

Feminist Poststructural \& Queer Theories of Gender ........................................................... 11

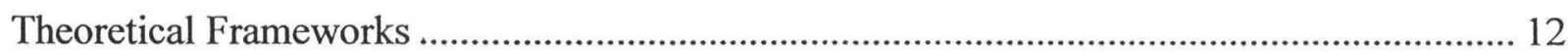

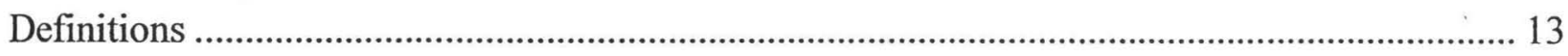

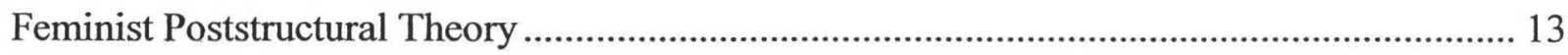

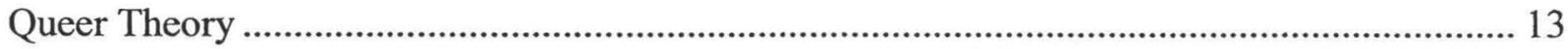

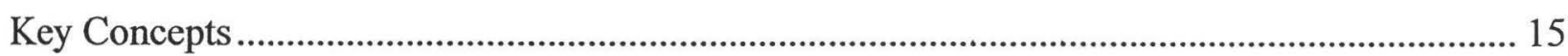

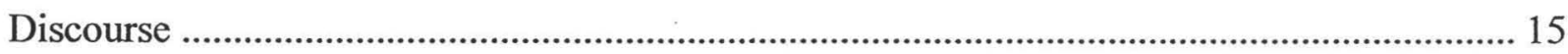

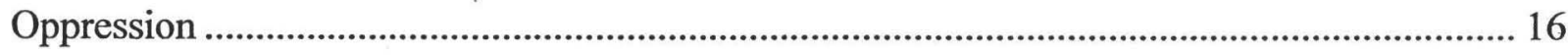

Identity as Dynamic \& Relational ............................................................................... 17

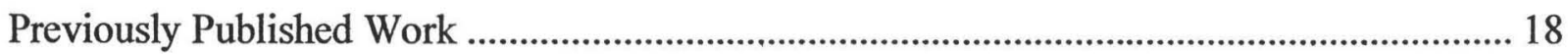


Representation of race in children's literature

Representation of class in children's literature

Representation of ability in children's literature 20

Representation of age in children's literature

Representation of body size in children's literature

Conclusion 23

Chapter 3: Methods. 25

Methodology 28

Ethics 29

Research Sites 29

Recruitment procedures to secure sites 30

Data Collection 31

Definitions of Key Terms 33

Convenience Sampling Definition. 33

Content Analysis Definition 34

Manifest content analysis 34

Latent content analysis. 35

Instruments. 35

Data Collection Grid. 35

The Statistical Package for the Social Sciences (SPSS). 36

Manifest content analysis instrument 37

Latent content analysis instruments 39 
Methods of analyzing children's literature for representation of diversity of gender

Methods of analyzing children's literature for representation of diversity of sexuality

Methods of analyzing children's literature for representation of diversity of race.

Methods of analyzing children's literature for representation of diversity of class

Methods of analyzing children's literature for representation of diversity of size

Methods of analyzing children's literature for representation of diversity of age. 44

Methods of analyzing children's literature for representation of diversity of ability..... 44

Queer theory qualitative analysis instruments 45

Validity \& Reliability 46

Conclusion 47

Chapter 4: Findings 49

Number of books analyzed 50

Year of publication of books 51

Manifest content analysis findings 52

Latent content analysis findings 53

Representation of diversity of gender 53

Representation of diversity of sexuality 55

Representation of diversity of race. 57

Representation of diversity of class 58

Representation of diversity of abilities 60

Representation of diversity of age 61

Representation of diversity of body size. 64

Qualitative Queer Theory Analysis of Two Books 66 
Queer analysis of And Tango Makes Three

Queer analysis of Olivia and the Missing Toy.

Conclusion 75

Chapter 5: Discussion 76

Major findings of this study...... 76

Representation of diversity of sexuality 78

Representation of diversity of race 78

Representation of diversity of class 79

Representation of diversity of ability 79

Representation of diversity of body size. 80

Adequacy of the Counting Method. 81

Alternate Methods of Exploring Representation 81

Limitations 81

Limitations of manifest content analysis 81

Limitations of latent content analysis 83

Limitations of queer analysis 84

Beyond Olivia and the Missing Toy 84

Beyond And Tango Makes Three 85

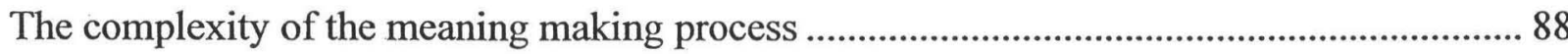

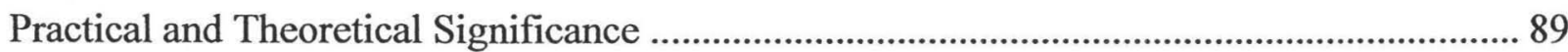

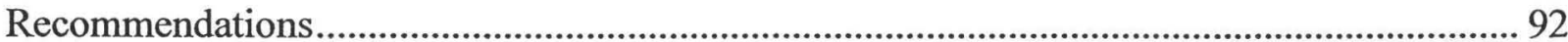

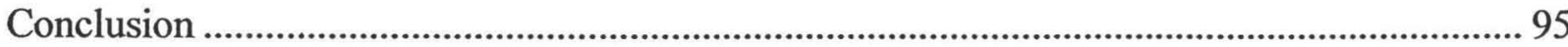

References......................................................................... 97 


\section{Tables}

Table 1. Graph 1 Data Collection Setting.............................................

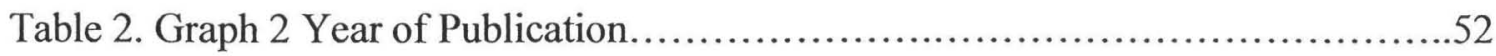

Table 3. Graph 3 Representation of Diversity- Race...............................58

Table 4. Graph 4 Representation of Diversity- Class..............................60

Table 5. Graph 5 Representation of Diversity- Ability ............................62

Table 6. Graph 6 Representation of Diversity- Age..................................64

Table 7. Graph 7 Representation of Diversity- Size.................................66 


\section{Figures}

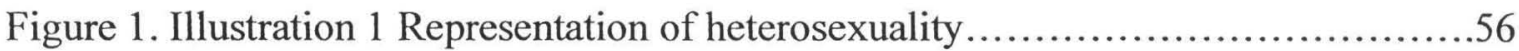

Figure2. Illustration 2 Representation of Class...................................59

Figure 3. Illustration 3 Representations of Age.................................63

Figure 4. Illustration 4 Representation of Size.....................................65

Figure 5. Illustration 5 And Tango Makes Three Illustration..........................69

Figure 6. Illustration 6 And Tango Makes Three Illustration..........................71

Figure 7. Illustration 7 Olivia and The Missing Toy Illustration........................73 


\section{List of Appendices}

Appendix A. Unofficial Ryerson Consent Agreement..............................110

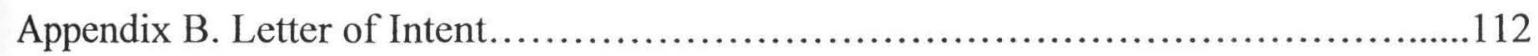

Appendix C. Letter of Confirmation to Participants...................................113

Appendix D. Coding Sheet................................................. 114

Appendix E. Data Collection...................................................... 117 


\section{Chapter 1}

\section{Introduction}

A significant number of research studies show that books, like blocks, play dough, and paint, are essential tools in every childcare setting. According to a study by Gerde and Powell (2009), on average early childhood educators (ECEs) spend 7 minutes per group session (often referred to as circle time) reading to preschool children. As circle time often occurs at least twice daily, it can be estimated that ECEs spend approximately 70 minutes per week reading to children. This time is considered vital because reading with preschoolers provides potential opportunities for these children to develop decoding skills that beginner readers use to discover meaning in print and spoken language (Hindman, Connor, Jewkes, \&Morrison, 2008). Moreover, early literacy has been linked to many other aspects of a child's wellbeing including health, social justice (Green, 2008), earnings (Burnett, 2008), and global competition in a knowledge economy (Walker, 2008). Literacy intervention programs such as Action for Family Literacy Ontario (AFLO) promote literacy (Walker, 2008), advocate a love of language (Green, 2008), and portray literacy as a 'passport for life' that has the potential to significantly alter individual and societal realities (Burnett, 2008). While the importance of literacy is quite clear, surprisingly, there appears to exist a general lack of attention to representation of diversity when early childhood educators select children's books (Paterson \& Lach, 1990).

In order to promote diversity in early childhood education, books that reflect varying types of backgrounds and 'identity' are readily used. However, this trend did not develop until the 1960s and 1970s when book publishers identified gender stereotypes and unequal representations of girls portrayed in children's books (Paterson \& Lach, 1990). Liberal 
feminist researchers used a latent content analysis counting method to explore representation and stereotypes of gender in children's literature. The American Psychological Association (2008) defines gender as a psychological phenomenon, which refers to learned sex-related attitudes and behaviours (Mertens, 2009). According to Clark (2002) the work of social scientists such as Weitzman (1972) opened up an important dialogue regarding gender issues in children's literature. Weitzman's work helped ameliorate publishing practices, produced a decrease in the recognition of books with sexist undertones, and led to modifications in writing practices (Clark, 2002). Poststructural feminism is concerned with deconstructing the dominant discourse, and focuses on social change for women and other marginalized groups. The intersections of gender with other systems of oppression and privilege are key to poststructural feminist ideology (Tisdell, 1998). Poststructural feminist theory "provides means to examine and deconstruct 'the problem' of gender" which has been discursively shaped, with male and female dichotomized as opposing (Allard \& Cooper, 1997). Blaise asserts, "understanding discourses and how they work in a classroom setting is a vital and necessary step toward understanding how gender is socially constructed and contested" (Blaise, 2005, 17).

For ECEs, books are used to entertain, teach, and promote diversity. Global measures of classroom quality used to inform early childhood education practices such as the Day Nursery Act (DNA), Early Childhood Environment Rating Scale (ECERS; Harms, Clifford, \& Cryer, 2005), and Developmentally Appropriate Practice (DAP), compiled by the National Association for Educators of Young Children (Bekkendal, 1987), all include access to books as a mandate in early childhood education. These texts also promote representation of diverse populations in childcare environments. For instance the ECERS 
document was developed to encourage program improvement and the inclusion of children with disabilities and cultural diversity (ECERS; Harms, Clifford, \& Cryer, 2005). Similarly, in Ontario, The Best Start Expert Panel on Early Learning, compiled in 2006, titled Early Learning for Every Child Today (ELECT) can be used to measure quality in daycare and guide ECEs to ensure "a wide selection of books are accessible for a substantial portion of the day." According to the ELECT document, these books should reflect different cultures and abilities. Likewise, the DAP recognizes the impact of cultural and linguistic contexts, and promotes validation of variations in the individual development of children (Bekkedal, 1987). Some areas of diversity are not explicitly addressed in many of the documents that inform ECE practice. For example gender, class, age, body size, and sexuality are often ignored in documents referred to as quality indicators in early childhood education and poststructural reconceptualists are beginning to challenge some of these texts.

A reconceptualist movement is occurring in North America as scholars and ECEs are beginning to question the practices of professionals working with children (Swadener\&Cannella, 2007). This movement is challenging the very documents that inform “best" practices (Pacini-Ketchabaw\& Pence, 2005) such as the DAP (Bekkedal, 1987). According to Pacini-Ketchabaw, and Pence $(2005,5)$ the reconceptualist movement has not yet achieved popularity in Canada; however, "assumptions of universality" and "singularity" are currently being challenged. Professionals in early childhood education have been invited to join this movement, which acknowledges differing views and invites people to think in a way that disrupts long-held beliefs, including classification and description. Reconceptualist scholars are challenging "truth," and contributing to the diminishment of notions of what children "should" be or do (Pacini-Ketchabaw\& Pence, 2005, 6). According to Grieshaber 
\& Cannella (2001), some prominent features of the reconceptualist movement include the promotion of race, class, gender, sexuality, nationalism and age as intersectional.

Inspired by the reconceptualist movement, this research project has attempted to uncover our notions of diversity in early childhood education through exploring representation of diversity in children's literature. Feminist poststructural theory, which explores how the dominant discourse constructs "truth," is one of the theoretical frameworks that have informed both the reconceptualist movement and this preliminary research project. This project has also been informed by queer theory, which views identity as dynamic and interconnected, and challenges popular notions of "truth" (Blaise, 2005). Illustrated books present societal and cultural values and impart societal norms (Paterson \& Lach, 1990); therefore, in order to determine how diversity is represented in children's literature this study has considered books as artifacts of early childhood education. This research project's aim has been to answer the following questions:

1) Does children's literature currently used in early childhood classrooms reflect diversity of gender, sexuality, race, class, ability, age, and body size?

2) Is the counting method adequate to examine representation of diversity in children's literature?

3) Are there alternate methods of exploring representation of diversity in children's literature?

4) How can issues of gender, sexuality, race, class, ability, age, and body size in children's literature most effectively be brought to the attention of early childhood educators?

According to Clandinin \& Connelly (2000), experiences shift and change during any given research process, which inevitably results in a need for negotiation and reevaluation. 
This preliminary research project has experienced significant changes. A need for a paradigm shift became apparent during the data analysis process and the need for more sophisticated criteria for analyzing children's literature became evident. A manifest content analysis from a liberal feminist approach was performed in order to measure the frequency of representation of heterosexuality in the texts under study. A latent content analysis which was inspired by a poststructural feminist approach was also added. This latent content analysis was used to investigate gender, sexuality, race, class, ability, age, and body size of characters in children's literature to highlight how each is represented. Queer theory explicitly concerns itself with issues of sexuality, particularly heteronormativity, and has therefore supplemented feminist poststructuralism in order to look beyond the quantitative data for a qualitative queer exploration of two selected book titles. 
Literature Review

The different ways gender has been researched in children's literature will be highlighted in an attempt to gain insight into the approach towards analyzing diversity in children's literature. Furthermore, it will become obvious throughout this paper that exploring issues of gender from the perspective of feminist poststructuralism and queer theory requires a consideration the representations of sexuality. Therefore after introducing the theoretical frameworks that inform this research, sexuality in children's literature will be explored. Both feminist poststructuralism and queer theory acknowledge that identity is dynamic and interconnected with other aspects of identity; therefore, gender, sexuality, race, class, ability, age, and body size will be explored in order to provide a context for investigating the representation of each of these factors in children's literature. Exploring components of identity as independent and fixed using dominant discourse binaries such as male- female, black-white, and able-bodied and disabled may not fully reflect feminist poststructural theory and queer theory, but will serve to shed light on oppression. The selected methodology may create new possibilities that acknowledge the ways in which early childhood educators contribute to the negotiation and construction of identity of children and lead to an examination of intersecting sources of disadvantage. Lastly, oppression, as it relates to diversity, will be explored in order to inform the recommendations section that is concerned with discovering ways to engage ECE's in a discussion about diversity in children's literature. 
For the purposes of this paper, "children's literature" is defined as books written and illustrated for children aged zero to eight. Children's literature typically refers to picture books illustrated with colourful and bold images. Illustrators use a variety of mediums to create images for children's literature including paint, photography, collage, and plasticine. Illustrations usually correspond with text and supplement stories, providing an opportunity for emergent readers to "read" the pictures (O’Donnell \& Wood, 1999). Animals with human characteristics (anthropomorphism) are in many early childhood stories. Assigning a human trait to an animal or object is said to provide a "buffered engagement with a message of cultural significance ... and ease the tensions dealing with issues not yet fully resolved or socially controversial" (Burke, Copenhaver, 2004, 210). The text in literature for very young children is often simple and easy to follow. Furthermore, children's books have "story language" which is unique to children's literature as it is much more rich than language used in typical conversations. Sometimes the order of words is altered in the interest of rhyming (O'Donnell \& Wood, 1999), which is popular in children's literature. Although the language is typically quite simple, children's books expose children to social identities and cultural scripts that have an invested interest in disciplining children into normative beings (Marshall, 2004). In fact, according to Lystad (1980), children's books have the power to sustain and transform the culture of the world (as cited by Paterson \& Lach, 1990).

Saltmarsh asserts that children's literature serves to re-circulate discourses already present in the world which in turn "(re)shape" social realities $(2007,97)$.

\section{Gender}


Not surprisingly, gender is a prevalent feature of children's literature; almost every child's book involves human or animal characters that are identified as male or female through the use of the pronouns he or she. Gender has been considered across many disciplines, and those researchers who believe that gender is bred in one's genes consequentially attribute all differences to biology (Shaffer, 2000). Biological theories of gender assume that social roles are allocated based on biological sex (Marshall, 2004). In contrast, social theories of gender posit that children learn gender through modeling and reinforcement within society and culture (Blaise, 2005). According to the theory of social learning of gender, indoctrination is established through a social prescription that imposes values, motives, and classes of behaviors considered "gender-role standards" for girls and boys (Shaffer, 2000). Essentializing theories of gender (such as social and biological) reduces all femininities and masculinities to a simple and particular way of being male or female (Blaise, 2005). Furthermore, according to Blaise (2005), if children are believed to act based on biologically "natural" influences and the social influences of family and society, addressing issues of gender may seem futile.

\section{Research of gender in children's literature}

To date, many scholars have examined social issues such as gender in children's literature. However, biological and social theories of gender have informed much of the previously published research. For instance, Weitzman, Eifler, Hokada, and Ross (1972), who were among the first social scientists to explore issues of gender in children's literature, used a liberal feminist method of counting. This theoretical approach greatly influenced Weitzman et al. (1972) who were among the first to study gender bias in children's literature. Weitzman's work shaped several studies that measured gender bias in children's 
literature utilizing counting methods. For example, according to Clark and Fink (2004) 27 of 34 studies looking at issues of gender in children's literature, used a liberal feminist approach inspired by Weitzman's prominent work. Narahara (1998) is but one social scientist that analyzed picture books using Weitzman's methodologically reputable work to explore issues of gender. Part of Narahara's study included counting how many times males versus females were represented in children's books. Liberal feminism, which concerns itself with issues of equality, advocating for equal representation of males and females, as well as diminished stereotypes, posit biological sex as being responsible for social role allocation of men and woman (Marshall, 2004).

One of the most significant dilemmas in a liberal feminist reading is the need to sustain rigid male/female binaries (Marshall, 2004). According to Weedon (1997), liberal feminist approaches lack a radical critique of the conventional family, which reflects essential identity constructions. Furthermore, Calixte, Johnson, and Motapanyane (2005) insist that liberal feminists privilege the objectives of white middle or upper class woman by neglecting issues of race and class. According to Weedon (1997), feminist politics can be considered adequate when classism, racism, and heterosexism are taken into account.

Despite the aforementioned shortcomings of liberal feminist informed research, the work of Weitzman et al. did reveal some important findings. Liberal feminism has guided almost all research by feminist social scientists of children's books and this method has been effective in shedding light on issues of gender (Clark \& Fink, 2004, 104). Many studies that consider gender representation in children's literature have relied on what is referred to as the paradigmatic study done by Weitzman and her coauthors (Clark \& Fink, 2004). The use of this study has resulted in a well-established, seemingly credible methodology. Weitzman 
studied Caldecott Medal books, Newberry Award winners, Little Golden books and etiquette books published from the 1940s to the 1960s (1972). This study revealed "an under representation of females in titles, central roles, and main characters" (Weitzman, 1972). Weitzman's method of counting inspired many researchers to follow suit and analyze representations of gender in children's literature, however there has been a shift in feminist research that rejects the notion of women as victims of patriarchy and male sexuality. For instance, feminist poststructuralism is encouraging a positive representation of women who have the capacity to choose from an array of lifestyles (Marshall, 2004).

Scholars are challenging "problematic findings" of traditional feminist research to reflect a shift in feminist thought (Marshall, 2004, 256), however, gender continues to be the main focus. For instance, Marshall analyzed representations of gender by drawing on theories informed by poststructuralism and explored how concerns of "gender and sexuality play out in the language" of books in a way that perpetuates "cultural practices" $(2004,268)$. It is implicit that there are two sexes, male and female, and the two genders balance each other in a way that compels heterosexuality (Rothing, 2008). Butler views hegemonic discourses of gender as defining 'normal' gender performances, which serve to police heterosexualized performances of gender (Robinson, 2006). In other words, knowledge (for example, about being female) is produced through a discursive construct that shapes social categories (Marshall, 2004). Slagle (2003) supports this claim asserting that sexuality is always present and influential as we reproduce gendered identities.

Queer theorists are also beginning to challenge conventional representations that impact young people. For instance, Lester analyzes nursery rhymes with the goal of introducing discussions in which every child can be represented (2007). Lester's essay on this 
topic is riddled with exerts from other sources that reflect the experience of homosexuals in order to explore the extent to which children's texts perpetuate heteronormativity (2007). While Lester's work fails to identify a clear methodology in its analysis, Slagle's presents a clear framework to interrogate sexuality and other differences in his consideration of the Hollywood personality Pee-wee Herman (2003). Slagle (2003) explores Pee-wee Herman using a queer theory lens providing a framework to challenge "conventional" representations. Slagle explores Pee-wee Herman to interrogate sexuality by bringing the supposedly personal and private to the forefront because Slagle believes that sexuality "is always - and, indeed, it must be - invariably public" $(2003,134)$. While heteronormativity only considers one "normal" way to be challenged (Slagle, 2003, 135), queer critics recognize the uniqueness of all individuals by acknowledging oppression and domination but also challenging essentialism and making sexuality central (2003).

\section{Heteronormativity}

Currently there is an interest in how heteronormativity, or the assumption that heterosexuality is 'normal,' plays out in preschool environments (Fox, 2007). Simply put, heteronormativity is defined as "the assumption that all people are heterosexual or that heterosexuality is the superior sexual identity" (Day, 2000, xxi). According to Robinson heterosexual beings are constructed when "gender and heterosexuality intimately and powerfully intersect"(2006, 141).

Feminist Poststructural \& Queer Theories of Gender

In early childhood education, the reconceptualist movement is concerned with new ways of observing gender that have been informed by feminist poststructuralist and queer 
theory. According to Blaise (2005), a rejection of Western assumptions is challenging suppositions about connections between biology and gender roles. Feminist philosopher Judith Butler, who is often referred to by feminist poststructuralists and queer theorists alike, asserts that gender and performativity are intricately involved. Performativity implies acting out masculine or feminine roles, thus constructing a subject that, through repetition, strives for his or her performance to be accepted as real (Robinson, 2006). Poststructural feminists and queer theorists offer a paradigm in which femininity is not considered a natural category (Marshall, 2004). Redefined theories of gender now include the concept of heteronormativity, which involves the normalization of heterosexuality.

\section{Theoretical Frameworks}

Preconceived notions and fundamental beliefs about human nature inevitably influence research. In addition to being guided by personal theoretical frameworks, frameworks tend to guide what is noticed, and what is not noticed. According to Judith Butler, theory and practice are interdependent:

We are all, in the very act of social transformation, lay philosophers, presupposing a vision of the world, of what is right, of what is just, of what is abhorrent, of what human action is and can't be, of what constitutes the necessary and sufficient conditions of life. (Butler, 2004, 205)

By making implicit theoretical frameworks explicit, the task of selecting relevant research, choosing the methodological approach, analyzing data, and developing recommendations have been reasonably restricted.

This research project has been written using the theoretical framework of both feminist poststructural theory and queer theory. Both theories have been instrumental as a means of selecting relevant research articles, analyzing data, and examining and 
deconstructing the findings. In order to define each of these theoretical frameworks and highlight their legitimacy, crucial components of each theoretical framework will be discussed. Feminist poststructuralism and queer theory involves issues of power, language, discourse, and identity as dynamic and interconnected. Each of these elements of the theoretical frameworks will be elaborated upon, as they will be a theme in each chapter of this research project.

\section{Definitions}

Feminist Poststructural Theory

Blaise (2005) defines feminist poststructuralism as a means of producing new knowledge through exposing the mechanisms of oppression and revealing the possibilities of resisting gender to create new realities. Feminist poststructuralism also explores the politics of how "official" knowledge is both constructed and deconstructed (Blaise, 2005). According to Blaise (2005), language, discourse, subjectivity, agency, and power are allimportant poststructural concepts. Feminist poststructuralism recognizes identity as interconnected with other aspects of identity and will be used to inform an investigation of various aspects of identity.

\section{Queer Theory}

Queer theory has been informed by feminist poststructuralism, which also challenges normative practices, particularly about constructions of gender and sexuality (Robinson, 2006). Queer theory will supplement the feminist poststructural analysis of children's literature as scholars using queer theory have provided frameworks to model this research on. Furthermore, queer theory has provided a means to challenge notions of heterosexuality 
through critically analyzing and interrogating it as normal (Rodriguez, 2007). According to Slagle, queer theory is defined as:

A reaction to: (1) an oppressive, heterosexist mainstream, and (2) an approach to theory that focuses on social assimilation as its goal and has emphasized an essential notion of identity in order to foster collective activity $(2003,130)$.

A significant function of queer theory is to challenge notions of heterosexuality through critically analyzing and interrogating it as normal (Rodriguez, 2007). Queer theory is understood as a progressive step in the direction of "inclusivity and the celebration of differences" (Slagle, 2003, 130). According to Rothing (2008), using the term 'us' when referring to the concept of 'other' has the potential to reproduce the status quo. A proposed solution is to "deconstruct the discursive practices through which the social world is portrayed," so that identity can be problematized (Maynard, 1995).

The work of literary theorist Mikhail Bakhtin is being used to explore identity construction and offers some ways of understanding identity. Bakhtin introduces a concept of 'chronotype' which is a way of understanding experience and interactions in a specific time and space which renders identity construction somewhat dependent on where and when it occurs (Lacasa, des Castillo, Garcia-Varela, 2005). A Bakhtinian approach considers multiple voices, perspectives (heteroglossia) and interactions (dialogism) among early childhood professionals, ECEs with children and parents, as well as among children themselves (Shields, 2007). According to Yin-Kun, binaries that contribute to essentalizing normativity could be disrupted through queer carnival and heteroglossia bringing democratic experiences to bodies (2007). In contrast with a traditional schooling model, Bakhtin's "novel" approach emphasizes such things as inquiry, openness, diversity, and contextualized learning (Shields, 2007). If, as educators, we opt to participate in chronotope time space, 
consider plurality of voices within our environments (heteroglossia), and engage in dialogic interactions with joyful and spontaneous introductions of power dynamics (carnival) a Bakhtinian educational reform would be possible (Shields, 2007).

\section{Key Concepts}

Discourse

Discourse refers to a "theoretical grid of power and knowledge" that, according to Foucault (1980), is inextricably interconnected (Blaise, 2005, 16). Furthermore, discourse is a way of "speaking, writing, thinking, spelling, or acting" that involves certain ideas as "truths" (Blaise, 2005, 16). These perceived "truths" influence how we think and relay messages about power with dominant discourses appearing natural (Blaise, 2005). The dominant discourse in early childhood education fails to recognize the relevance of issues of power and language. These discourses are informed by rigid binaries, perceptions of children as too young and innocent, as well as cognitive developmental theories of development. According to Butler (1990), ECEs who believe children are too young to understand sexuality are neglecting the fact that sexuality is already taught through our understanding of gender construction (as cited by Robinson, 2006). For instance, sexuality can be observed in dramatic areas where mock weddings occur, as well as children pretending to be mothers and fathers having and raising children. Therefore, what discourse in early childhood education is actually saying is, 'issues of sexuality are not inappropriate, but that non-normative sexualities are' (Slagle, 2003). Furthermore, our current discourse depicts heterosexuality as "normal" or "natural," therefore rendering other sexualities "abnormal" and "unnatural" or ignoring them completely (Slagle, 2003). Messages to this 
effect are provided regularly, enforcing the idea that heterosexuality is the right way to live, moreover that a particular kind of heterosexuality is normative (Slagle, 2003).

\section{Oppression}

According to Tatum, certain elements of identity are "taken for granted by the dominant culture" while others are deemed as "other" (Adams et al. 2000, 11). Tatum elaborates stating "race or ethnicity, gender, religion, sexual orientation, socioeconomic status, age, and physical or mental ability" are all platforms for defining people as other (Adams et al., 2000, 11). Forms of oppression associated with each of these categories include: "racism, sexism, religious oppression/anti-Semitism, heterosexism, classism, ageism, and ableism" (Adams et al., 2000, 11). Zuniga (1997) points out the importance of recognizing all systems of oppression as "systemic and interlocking" but not immune to dismantling (Adams et al., 2000, 448), while Pharr insists that "all oppressions are connected" leaving many individuals struggling to gain access to justice and full participation in life decisions (Adams et al., 2000, 450, 451).

Omitted information can also be considered an oppressive act. Failing to acknowledge an individual or group by not providing a voice or representation leads to prejudiced behaviour; prejudice can be understood as a "preconceived judgment or opinion, usually based on limited information" (Tatum, 1997, 79, as cited in Adams et al., 2000). Internalized oppression is another form of oppression which occurs when a potential risk or stereotypical category is assigned to groups or individuals who have limited positive representation in society. Internalized oppression can occur as a result of a bombardment of stereotypical images and messages which become internalized so that the oppressed group 
comes to believe inaccurate things about themselves as truth (Tatum, 1997, 80, as cited in Adams et al., 2000).

Identity as Dynamic \& Relational

Slagle (2003) asserts that the distinction between liberal feminism and feminist poststructural and queer theory is that the former focuses on essential identity constructions while the latter is concerned with fractured and individual identity. Wildman and Davis $(2000,57)$ assert that "every individual exists at the centre of multiple intersections," which results in multi-dimensional complex individuals. Meanwhile Maynard (1995) writes that theories that consider the interconnectedness between forms of oppressive power with pluralistic notions provide an opportunity for individuals to "resist, struggle, and act". Scholars once focused solely on issues of gender; however, intersectionality was developed in response to the problem of exclusion and researchers began to examine intersecting sources of disadvantage. Intersectionality recognizes that gender cannot be separated from sexuality as the two are inextricably linked.

Because identity is interconnected, fluid, and complex, I will extend my initial investigation to move beyond gender and sexuality. I aim to discuss what the literature says about the representation of diverse elements of identity in such categories as race, class, ability, age, and body size. Both feminist poststructuralism and queer theory are legitimate theoretical frameworks that are appropriate for this research project as they recognize identity as complex and dynamic (Tisdell, 1998); however, queer theory locates sexuality rather than gender as central. Therefore, queer theory has been used to complete an in-depth reading of two books from this study by exploring the interaction of various identities and experiences of exclusion based on sexuality. 
A plethora of research examining representation of diversity in children's literature is available for most of the issues explored in this study. The following section will highlight some of the major findings about what scholars say about sexuality, race, class, ability, age and body size in children's literature.

Representation of sexuality in children's literature

The first picture book for young children that resisted oppression and celebrated difference by reflecting lesbian and gay members of society was Susanne Boshes' Jenny Lives With Eric and Martin, published in 1983 (Clyde \&Lobban, 2001). By 1992, ten picture books depicting gay and lesbian families had been located by Clyde and Lobban (2001). Amongst the titles were: Asha's Mums (Rosamund Elwin \& Michele Paulse), Heather Has Two Mommies (Leslea Newman), and Daddy's Roommate (Michael Willhoite). Clyde and Lobban (2001) found a total of 32 gay-friendly titles in 2001. Many of these titles have appeared on the Top 10 Most Challenged Books list due to such things as supposedly challenging family values. The Gay, Lesbian, and Straight Education Network (GLSEN) (2003) indicates that the shortage of gay-friendly picture books found in classrooms and libraries, means an estimated 6 to 14 million children cannot see an accurate reflection of their own experiences.

Reading stories of nuclear families and can contribute to enforcing "compulsory heterosexuality" (Rodriguez, 2007). Rowell (2007) asserts that despite the potential to erase homophobia, fewer than 80 gay-friendly children's titles published in the U.S. have reached the marketplace and go out of print quickly. Clyde and Lobban (2001) and Wolf (1998) 
concur that access to picture books related to homosexuality is a concern. One speculation as to why accessibility to gay-friendly books is limited is that many of the titles on the list of the 100 Most Frequently Banned Books of the Decade (released by the American Library Association in September 2000) are placed there because they "[promote] homosexuality as a normal lifestyle" (Clyde \& Lobban, 2001). According to novelist Nancy Garden, books that help bring gay and lesbians out of invisibility can "save lives" as ignorance is diminished through honest accurate books that help counter homophobia (forward in Day, 2000, xii). According to children's literature author Larry Dane Brimner: "in every school, in every city, in every state, in every country, there are sexual-minority youths who are wishing desperately to find themselves portrayed in books" (Day, 2000, 185). By inadvertently or deliberately failing to include books that reflect homosexuality (Rubin, 1995) educators fail to promote a positive self-image for each of their students.

Representation of race in children's literature

Early scholars such as Bekkedal (1973) found that in addition to researching gender stereotypes in children's literature, an interest also developed in the lack of representation of visible minorities and multiculturalism in these same texts. Multiculturalism is defined broadly as any group identifiable by certain demographic characteristics, such as colour, religion, geographic location, and language (Agosto, Hughes-Hassell, \& Gilmore-Clough, 2003). Studies exploring multiculturalism in children's literature found that middle-class, Caucasian American society was predominantly featured (Bekkedal, 1973). However, thirty years later, Agosto, Hughes-Hassell, and Gilmore-Clough (2003) found there was a growing awareness of diversity and therefore an increase in the publishing of multicultural literature for children. More recently, Rowell (2007) found that most early childhood education 
programs offer multicultural and multiracial books that represent children from diverse cultures and provide an opportunity for all children to learn about different cultures. Although Fox (2007) corroborates the claim that most schools include books that reflect people of colour, racism still exists in society today.

\section{Representation of class in children's literature}

According to Langston (1988), class is not about income and money so much as it is a culture that has been socially constructed (Adams et al., 2000, 398). Langston (1988) elaborates that the class you are born into informs your understanding about the world around you, and is influential in all aspects of life (as cited in Adams et al. 2000). Langston, who asserts that "the whole structure of education is a classist system" (Adams et al., 2000, 399) recognizes that ignoring the system of oppression based on class supports a cycle of poverty (Gorski, 2008, 34).

A search of literature that explicitly explores socio-economic class in children's literature revealed little, however Saltmarsh (2007) has explored this topic from a poststructural lens. The aim of Saltmarsh's research was to provoke a dialogue regarding "assumptions about childhood in relation to prevailing social and economic order, which are presented to children as natural and inevitable" $(2007,97)$. Beyond promoting consumption to children through books explicitly created for "larger commercial endeavor(s)," Saltmarsh argues that children's literature positions individuals to "recognize and take up their 'rightful' place in the social and economic order" (Saltmarsh, 2007, 101).

\section{Representation of ability in children's literature}


Statistics Canada (2007) indicates that 202, 350 children are disabled. Moreover, in $3.7 \%$ of these cases including developmental challenges, chronic health conditions, mobility challenges, or psychological problems, the amount of boys suffering outnumber girls.

Furthermore, this 2006 census discovered that $14.3 \%$ of all Canadians are disabled. Some medical understandings of disability inaccurately posit individuals with disabilities as victims who require care and whose disabilities require fixing in order to make the patient 'normal.' In contrast, social understandings of disability posit disabilities as a limitation "imposed on them by attitudinal, social, cultural, economic, and environmental barriers to their participation in society" (http://www.disabilitykar.net/learningpublication/whatisdisability.html).

According to Kaiser (2007), it is crucial that in our progressively inclusive early education environments, literature should reflect acceptance of disabilities or special needs. Kaiser acknowledges the challenges of locating inclusive children's books and found that children's books often present inaccurate portrayals of disabled people as tragic victims, or needy recipients of charity who are defined by their disability $(2007,67)$. Furthermore, books featuring disabled people often lack an exciting storyline and are meant to be more informative than entertaining.

Representation of age in children's literature

Difficulty determining what qualified as "old age" for this research study was encountered as even the World Health Organization (WHO) acknowledges that establishing a standard numerical criterion is challenging (http://www.who.int/healthinfo/survey/ageing). In North America, it is generally accepted that 60 and older is when one enters into old age as this is the age that pension benefits begin. The Canadian Network for the Prevention of 
Elder Abuse (CNPEB, 2004) has identified some myths about older adults including the belief that their lives are less valuable. According to Blumefeld and Raymond (1988), ageism constitutes discrimination based on age and usually occurs in relation to the elderly and the young (Adams et al., 2000, 25). The Ontario Human Rights Commission acknowledges that ageism is a "socially constructed way of thinking about older persons based on negative attitudes and stereotypes" (www.ohrc.on.ca, 2009).

According to Taylor (1977), children's literature provides children with a limited and stereotypical portrayal of old age. Fillmer (1983) concurs, citing a study that confirms that children perceive elderly people as inactive, lonely, and nonproductive. Fillmer also found that children expressed discomfort socializing with elderly individuals due to unrealistic attitudes and perceived limited exposure to older people and the aging process (1983). A more recent study investigating the role of grandparents and the ways in which they are represented in stories and literature stresses the importance of enhancing children's comprehension about the role of grandparents (Zeece, 2007). Zeece highlights our increasingly aging society and the changing role of grandparents, and promotes reinforcing an appreciation for the important role grandparents can play in children's lives (2007).

\section{Representation of body size in children's literature}

Body size is often a dominant characteristic of identity that is used to distinguish people. According to Keeling and Pollard, negative characteristics are often associated with being overweight and larger people often suffer from maltreatment (2008). Wang agrees stating, "being fat is one of the most devastating social stigmas today" $(2008,1900)$. This discrimination is referred to as sizeism and is based on the size of one's body and is 
generally directed at those who do not conform to idealized body shapes (Keeling \& Pollard, 2008).

According to $\mathrm{Su}$ (2008), preschool children perceive overweight children as having more negative characteristics than non-overweight children. Nuciforo and Chin (2009) assert that our society perceives larger individuals in a demeaning way leaving few positive role models with whom overweight children can identify. According to Wedwick (1998), prejudices against overweight people are "reinforced through literature" which propagates the belief that it is acceptable to discriminate against people based on their size. Overweight children are often portrayed as bullies with "fatness" used to "connote corruption of inner character, weakness, immaturity, and flaws that need to be fixed" (Rabinowitz, 2003, 1). Keeling and Pollard have explored the negative depiction of the larger child as a "cultural construction" which has up until now not been challenged (Keeling \& Pollard, 2008).

\section{Conclusion}

At the outset of this MRP, the link between gender and heteronormativity was explained through an account of what scholars have studied about these categories in children's literature. The purpose of this literature review has been to provide a further historical context for researching representation in children's literature. Specific attention to issues of gender, sexuality, race, age, class, ability, and body size has been undertaken in order to acknowledge the intersectionality of identity. For similar purposes, theories of oppression have also been considered.

The AECEO's code of ethics calls on professionals to provide a program that promotes self-esteem by recognizing and respecting uniqueness and acceptance of all 
children regardless of their race, religion, gender, nationality, or class. Joining the poststructural- and queer theory-inspired reconceptualization movement in ECE is crucial as continuing to neglect elements of identity is no longer acceptable. According to Foucault (1978), "What is spoken is as powerful as what is unspoken" (as cited by Robinson, 2006: 163) and our silence in early childhood education is too compelling to be ignored. 


\section{Chapter 3}

\section{Methods}

Children's literature is a powerful tool in early childhood education and has therefore been the focus of this preliminary research project. The theoretical frameworks selected for this research project reflect an academic journey in figuring out a method that would yield the most accurate information. The methodology involves three stages, each more sophisticated than the last and compensating for shortcomings of previous attempts. As will be revealed in future chapters, findings from each stage of research resulted in compelling findings that may be useful to initiate dialogue with ECE's about diversity in children's literature. This chapter highlights the methodological steps involved in answering the following research questions:

1) Does children's literature currently used in early childhood classrooms reflect diversity of gender, sexuality, race, class, ability, age, and body size?

2) Is the counting method adequate to examine representation of diversity in children's literature?

3) What are alternate methods of exploring representation of diversity in children's literature?

4) How can issues of gender, sexuality, race, class, ability, age, and body size in children's literature most effectively be brought to the attention of early childhood educators?

Systems that serve to oppress individuals based on one aspect of identity are also instrumental in the oppression of other aspects of identity. According to Gorelick, all systems 
of oppression "intersect and implicate virtually everyone" and "compulsory heterosexuality shapes sexuality, economics, and gender inequality" (1996, 37, 41). For example, according to Washington and Evans $(2000,316)$ "heterosexism is an area of oppression that cuts across, but is not limited to, race, ethnicity, gender, class, religion, culture, age, and level of physical or mental ability". Although one theme of this research is that identity is interconnected, for the purpose of this project, elements of identity will be categorized and defined according the dominant discourse binaries such as male-female, heterosexual-homosexual, and young-old. These binaries have been reproduced deliberately as it has been deemed the best possible way to highlight representation (or lack thereof) of diversity in children's literature. In attempts to identify the representation of diversity in children's literature, uncovering the dominant discourse that may fail to recognize identity as interconnected was believed to be a starting point to initiate dialogue with early childhood educators. The research findings can serve as a tool to promote discussions to challenge "truth" and hopefully contribute to challenging all forms of oppression. The use of queer theory has been added to this research study in order to critically interrogate identity construction, in particular sexuality in children's literature.

The first stage of this research project was a latent content analysis measuring representation of sexuality in children's literature. Weitzman et al. (1972), who were among the first to study gender in children's literature, used a counting method to shape several studies that measured gender bias in children's literature. For example, Narahara (1998) prepared a study of children's literature by counting the respective representation of males versus females in a variety of texts. Narahara's liberal feminist investigation of gender in children's literature will serve as a model for the first part of this preliminary study to explore issues of sexuality. This section of the study has utilized Narahara's counting model to 
determine if this method is adequate for examining the representation of sexuality in children's literature. Subsequent chapters have illustrated that this method of analysis has revealed inaccurate findings and therefore requires more sophisticated methods of analysis.

More recently, feminism has been redefined and feminist poststructural scholars now recognize identity as interconnected with gender, sexuality, race, class, ability, age, and body size. The second stage of this research project involved using a manifest content analysis to explore the representation of various elements of identity. Furthermore, this stage of the research project will serve to determine if alternate methods of exploring representation of diversity in children's literature exist, feminist poststructuralist latent content analyses have been employed. This latent content analysis, which will be discussed in more detail later, has served to compensate for the limitations of traditional feminist research methods. In addition to careful examination of what is said, this supplementary research has analyzed thick descriptives of each book for what is not said such as a failure to represent diversity of gender, sexuality, race, class, ability, age, and body size. Although feminist poststructuralism lacks an official methodology, the work of Elizabeth Marshall has informed the methodology for this section (Marshall, 2004). Marshall utilizes a feminist poststructural framework to investigate the Little Red Riding Hood tales and believes that simplistic identity markers in children's literature need to be disrupted (Marshall, 2004, 269).

The third stage of this research project has involved using a queer lens to investigate two titles. In addition to considering children's literature from a feminist poststructuralism perspective, this same literature has been investigated for representations of diversity through the lens of queer theory. The work of Anthony Slagle (2003), who explores Pee- 
wee Herman television episodes and movies using queer theory, has been referred to throughout this study as a framework. Using queer theory, the shortcomings of both latent and content analysis have been highlighted and discussed. Subsequent chapters have answered the last research question investigating how issues of diversity in children's literature can effectively be brought to the attention of ECEs to promote deliberate book selection and possibly a celebration of difference in early childhood education.

\section{Methodology}

In addition to studying 109 books from four classrooms, early childhood educators from each class have provided ten books that were read to children throughout the year, but are not available in the classroom. A mixed method content analysis of both sets of books has been completed. Each item on the content analysis tool has been numerically coded (see appendix D for coding form) to measure the criteria outlined. A manifest content analysis and latent content analysis have been used as the coding operation, while The Statistical Package for the Social Sciences (SPSS) has been used to examine the quantitative data. As will be discussed in the findings and discussion sections, the need to go beyond the numbers of these quantitative methods became glaringly evident throughout the composition of this MRP. Therefore a qualitative investigation, informed by queer theory, has been used to consider two titles: And Tango Makes Three (Parnell, Richardson, Cole, 2005) and Olivia and the Missing Toy (Falconer, 2003).

The following chapter will provide a thorough description of the ethics procedure, definitions of the key terms, descriptions of the research sites, procedures used to secure sites and gather data, as well as a discussion of the instruments used. The last section will offer a discussion of how validity and reliability were accounted for in the study. 


\section{Ethics}

Since the researcher does not influence the illustrations and texts of books that have been analyzed in this study, this content analysis has been "unobtrusive" (Wallen \& Fraenkel, 2000, 421). As such Ryerson University's research ethics committee deemed an official ethics application unnecessary for the purposes of this research project. However, because this study has involved two daycare supervisors and ECE staff from four classrooms providing access to books, a formal ethics form (see appendix A) was completed and has been submitted to the supervisors involved in this study. Furthermore, voluntary informed consent information specifying the general intent of this study has been provided to all ECEs who agreed to provide access to books (see appendix B).

Additional ethical considerations include being considerate of the ECEs feelings and their experience with the research. ECE teachers who provided access to books available in their class as well as the 10 additional books from outside of the classroom were assured that granting permission to have books analyzed is voluntary and that they may withdraw approval at any time. Names of daycare sites have not been disclosed, nor have the names of the early childhood professionals who are employed in the classrooms of each site. In addition to these ethical considerations, integrity has been demonstrated by accurately representing the data collected from each site.

\section{Research Sites}

In the interest of time and for the sake of convenience, two childcare settings were selected based on previous knowledge of these locations. From January 2003 to January 2007, I was a full-time ECE employed at one of the childcare facilities involved in this 
study. From September 2008 to December 2008, I was employed part time as a supply ECE at a second childcare facility involved in this study. Furthermore, my daughter was enrolled in part-time care in the infant class of the childcare where I did supply work in 2008. These employment experiences, as well as my experience as a parent of a child enrolled in the childcare program, provided me with insight into the facilities. In addition, my involvement with each site as an employee and a parent increased my likelihood of being granted permission to complete research at the sites thus making this a convenience sampling.

\section{Recruitment procedures to secure sites}

After receiving notice from the Ryerson ethics committee that ethics approval would not be required for this research, and approval from my supervisor to proceed, securing research sites was the first task. For the purpose of this study I was interested in collecting data from sites that appeared to have an adequate budget to finance a collection of books. I was also interested in completing a study in a childcare setting where all full time ECE employees held a diploma or Bachelor of Arts in early childhood education. This criterion was set in an attempt to minimize the likelihood that inadequate funding was available for books or that the employees were not qualified ECEs. I felt that analyzing books from a childcare class where qualified ECEs have access to adequate funding would result in an ideal sample.

One of the first steps was to contact the supervisors from the two familiar childcare facilities to informally discuss the possibility of undertaking research at their sites. The supervisor of each childcare setting provided verbal permission for me to conduct a content analysis of the books available in two classes of each childcare. An email follow up letter outlining the proposed research was sent with a request for official permission (see appendix 
C). A permission form delivered to each ECEs from the two childcare sites resulted in four positive responses to complete a content analysis of their books. Two early childhood education teams from separate classes in each childcare site responded, thus securing my access to books in an infant, toddler, preschool, and kindergarten class. My goal of securing two classrooms located in one childcare site, and an additional two classes located within another childcare site was achieved; however, the fact that each age group is represented is a coincidence. An email attachment addressed to all of the ECEs employed in each childcare facility was sent to the supervisors of the two sites involved in this study. This attachment was a request form outlining my intention to explore social issues in children's literature though an analysis of the books available on the shelves and 10 additional books.

Four early childhood education teams (two classes from each of the two childcare sites) granted me permission to analyze the books available in their class as well as provide 10 selected books. Each of the early childhood education teams was contacted by telephone, email, or in person to individually arrange a convenient time and date to collect data. Emails confirming the agreed-upon dates and times were sent to each early childhood education team. In each classroom, the teachers agreed to collaborate with the team teachers to provide 10 books shared with children in their class throughout the year. The 10 books requested were not books typically available on the bookshelf in each class, but were selected by teachers to be shared during group or individual reading times. In order to be as unobtrusive as possible, it was agreed that data collection would occur during times when children and staff were not in the classroom.

\section{Data Collection}


Many researchers such as Heintz (1987) who examined fourteen Caldecott Medal Winners, and Albers (1996) who analyzed Caldecott Gold Medal Winners (Narahara, 1998) have focused on analyzing children's books that are award-winning. As was previously mentioned, according to Fink and Clark (2004), award-winning books do not typically represent sexual diversity. In recognition that not all teachers choose books based on their award-winning status, Narahara (1998) researched children's books submitted by four kindergarten teachers. Ten books were collected from each teacher and five were randomly selected from each collection for a total of 20 books. In a similar vein, the methodology of this research project has involved, as previously mentioned, researching books available on early childhood education bookshelves and ten additional books from each class provided by the ECEs.

The infant classroom had sixteen books on the bookshelf, and an additional ten books were provided by the ECE, for a total of 26 books analyzed in the infant category. The preschool classroom had 29 books displayed on bookshelves and ten books were provided by the ECE for a total of 39 preschool books. The toddler classroom had 12 books on the bookshelf and once again ten books were provided from the ECE for a total of 22 books. Finally, the kindergarten program also had 12 books displayed for children. Combined with the ten books provided by both the kindergarten and toddler ECEs, these classes had a total of 22 books each. The total number of books analyzed was 109 .

The books available from the various classrooms were the property of the childcare facility, except for a book on the preschool shelf called And Tango Makes Three (Richardson, Parnell, \& Cole, 2005), which was on loan from a preschooler's family. Children's books in each setting were obtained from a communal childcare collection 
available at each site and ECEs select class books from this collection. However, in the preschool class, both the preschool children and ECEs selected the books from the preschool book storage shelf. The ten books provided from each ECE were either from personal collections, or from a separate classroom collection of books purchased with funds allocated by the childcare supervisor.

After obtaining consent and agreeing upon a date and time, the names of the books, year of publication, publisher, and name and gender of the author were documented. The books available in each class, along with ten selected books, were examined for representations of diversity including gender, sexuality, race, class, ability, age, and body size. All data was recorded on prepared grids with a heading for all information collected. This information included descriptive comments about each book which was later used to analyze data and to assist in recall while entering data. The process took approximately three and a half hours per class setting, except for the preschool setting, which took five hours due to the significantly high number of books.

\section{Definitions of Key Terms}

\section{Convenience Sampling Definition}

According to Trochim (2001), convenience sampling, which is also referred to as accidental, haphazard, or opportunity sampling, is similar to psychological research using college students to collect data. This method of sampling involves choosing convenient samples in an unstructured manner from the population frame and it may involve asking for volunteers. Convenience sampling is the most commonly employed method of sampling as it is useful when it is not "feasible, practical, or theoretically sensible" to use probabilistic 
sampling methods (Trochim, 2001, 56). However, this method of sampling is a nonprobabilistic method and may not be the most accurate representation of the population (Trochim, 2001).

\section{Content Analysis Definition}

According to Babbie and Benaquisto $(2002,290)$ content analysis is a "coding operation" that transforms raw data into a standardized form. Content analysis is defined as the analysis of written or visual content that is used to identify occurrences within documents (Wallen \& Fraenkel, 2001). Content analysis of children's literature is a common tool that involves using a code sheet (see Appendix A) in order to analyze identified questions. For social scientists, using content analysis to explore issues of gender in children's literature is a good way of what Clark and Fink (2004) call "shedding light of a certain kind" on representation and stereotypes of male and female characters. According to Bekkedal (1973), content analysis offers a sound approach to research on children's literature, because it is objective and systematic. Bekkedal makes the assertion that content analysis provides a more comprehensive look at the contemporary world as represented in children's literature (1973). Babbie and Benaquisto concur, identifying content analysis as a useful method for investigating widely held assumptions in order to understand specific details (2002). Two different kinds of content analysis were used for this research project: manifest and latent.

\section{Manifest content analysis}

A manifest content analysis of documents considers the obvious content of text and illustrations, and involves counting the occurrence of "words, statements, concepts, pictures, 
images, and ideas" (Wallen \& Fraenkel, 2001, 408). The "visible surface content" is tabulated so that the frequency of an occurrence indicates the pervasiveness of the issue being studied (Babbie \& Benaquisto, 2002, 290). Manifest content analysis requires that numerical coding is assigned to data so that it can be quantified (Wallen \& Fraenkel, 2001).

\section{Latent content analysis}

Latent content analysis is aimed at accessing the underlying meaning behind what is written or shown (Babbie \& Benaquisto, 2002). The process for analyzing data using latent content analysis requires that one reads an entire communication (a book in this case) or a sample to "make an overall assessment" (Babbie \& Benaquisto, 2002, 290). This method of analysis requires a detailed description of the underlying meaning of the text and illustrations in order to make judgments or inferences. Like manifest content analysis, latent content analysis requires quantification of the data with numerical coding (Wallen \& Fraenkel, 2001).

\section{Instruments}

\section{Data Collection Grid}

Data collected over the course of this project has been recorded on a grid (see appendix F) with a section designated for documenting data for each category of study. The headings provide guidance for collection of the book title, author, year of publication, and gender of the author. Manifest content analysis headings include 'frequency of heterosexuality in text' and 'frequency of heterosexuality in illustrations.' Frequency of homosexuality is also tabulated and entered into the grid under the appropriate headings for analysis of text and illustrations. More sophisticated criteria to reflect the feminist 
poststructural revisions have been added to the original instrument. In addition to using this tool for a manifest analysis that counts the frequency of representations of sexuality, latent content analysis data has been collected under the headings gender, sexuality, race, class, ability, age, and body size. In addition to the modified criteria, a description of each book was collected under the heading "thick descriptive." The descriptive notes are intended to provide data for a latent content analysis of the underlying meaning of the books analyzed. To supplement this data collection, two books have been reviewed using a queer theoretical framework as a guide to complete qualitative research. The coding sheet (see appendix A) is an important instrument that provides structured guiding questions for all sections of this research project.

The Statistical Package for the Social Sciences (SPSS)

In order to keep track of the data collected, coding and memoing have been documented in order to create an audit trail. The numerically coded data has been studied using a manifest content analysis that measures the visible content by counting, and a latent content analysis that measures underlying meaning. Both manifest and latent content analyses have been performed for the coding operation, and the SPSS has been used to examine the quantitative data. The manifest analysis involves entering the frequency of homosexual and heterosexual relationships represented in text or illustration of the books analyzed. Furthermore, the number of times words indicative of a same sex relationships have been used such as queer, gay, homosexual, lesbian, same-sex, or boyfriends or girlfriends have also been identified and counted. Illustrations of heterosexual and homosexual relationships have been counted and entered into the SPSS program prior to 
tabulating the manifest content analysis data collected. The coding instrument has been relied upon to inform both the manifest and latent content analysis.

\section{Manifest content analysis instrument}

The aim of the manifest content analysis was to identify the adequacy of the counting method to examine representation of diversity in children's literature; this is also the first question posed by this research project. Narahara (1998) used manifest content analysis to consider issues of gender by exploring the surface content of text and illustrations in children's books. As is typical of liberal feminist methodology, this manifest content analysis involved counting the occurrence of "words, statements, concepts, pictures, images, and ideas" (Wallen \& Fraenkel, 2001, 408) and was influenced by Weitzman (1972). Narahara $(1998,3)$ used a replicated research design in order to measure gender bias in children's literature. Narahara's study examined the following:

1) Gender of author.

2) Number of males and females in central roles.

3) Number of males and females in secondary roles.

4) Frequency of female and male images.

5) Roles of the male and female characters.

6) Activity (active or passive) of the characters.

7) The use of male and female nouns, pronouns, and possessive pronouns.

The manifest content analysis of this preliminary research study follows a modified 
version of the work of Narahara (1998) with the criterion revised to focus on sexuality. Rather than exploring the roles of male and female characters, this study is concerned with the relationships of characters in children's literature. Narahara's consideration of gender has been revised to count the number of times heterosexual and homosexual relationships were represented in text or in illustrations. In order to explore sexuality in children's books, the manifest content analysis in this research has identified the frequency in which words meaning mother and father, grandmother and grandfather, or their synonyms have appeared together. The manifest content analysis of this study has examined the following:

1) Frequency of illustrations representing members of the opposite sex who appear to be in a romantic relationship.

2) Frequency of illustrations representing members of the same sex who appear to be in a romantic relationship.

3) Frequency of text representing members of the opposite sex using language that implies a romantic relationship. For example, mother/father, mama/papa, husband/wife, boyfriend/girlfriend, grandmother/grandfather or their synonyms.

4) Frequency of text representing members of the same sex using language that implies a romantic relationship. For example gay, lesbian, boyfriend/boyfriend, girlfriend/girlfriend, father/father, mama/mama, or their synonyms.

Although the gender of the author has been recorded, the sexuality of the author or illustrator is most often unknown; therefore, information about the author has not been explored in the manifest content analysis. Moreover, although Narahara investigates the 
central roles, secondary roles, and activities of characters in her study, this preliminary research project has simply focused on the frequency of heterosexual and homosexual relationships represented in text and illustrations.

\section{Latent content analysis instruments}

In order to answer the second research question, which asks if the counting method is adequate to examine representation of diversity in children's literature, a latent content analysis has been used to explore alternate methods. This section has also examined whether children's literature currently used in early childhood classrooms reflects diversity of gender, sexuality, race, class, ability, age, and body size. As previously mentioned a liberal feminist method of researching issues of gender by counting lacks an informed critique of the conventional family and reflects essential identity constructions (Weedon, 1997). For example, Calixte, Johnson, and Motapanyane (2005) insist that liberal feminists privileged the objectives of white middle or upper class woman neglecting issues of race and class. In order to account for the limitations of manifest content analysis, latent content analysis tools have been expanded upon using a feminist poststructural and queer theory framework.

A consideration of the interconnectedness of identity will guide the latent content analysis of each book which has been investigated to discern whether gender, sexuality, race, class, ability, age, and body size were represented or not. In part, a failure to locate research that explores intersecting identities in children's literature has informed this methodology which has explored aspects of identity independently. This study supports Bakhtin's claims that there is "no unitary self that is separated from other people encountered in everyday life and narratives" and that 'dialogic selves' are continuously 
interacting (Edmiston, 2007). This study also acknowledges that oppression based on identity does not act independently, but is based on the intersections of many forms of discrimination (Davis, 2008). However, drawing attention to dominant modernist assumptions about identity may serve to provide a starting point for dialogue about oppression and create possibilities to recognize identity as relational, dynamic, and potentially contradictory (Edmiston, 2007).

According to Rhedding-Jones, poststructural research resists "neat little boxes that look so nice," and involves "reconstructing what it means to do research" (as cited in Hall \& Marsh, 2003, 404). In an attempt to go beyond the traditional liberal feminist method of counting, this latent content analysis has focused on exploring what has been omitted. The latent content analysis data collected is indicated on the graph (appendix E) with either a one for representation of a specific diversity, or a zero for no representation. This information has been entered into the SPSS program for analysis.

The latent content analysis will be informed by the work of Marshall who insists that gender differences are not natural but instead dwell in language (2004). Furthermore, Marshall asserts that identity is fluid, and that "gender" is produced within particular cultural practices, stressing the importance of what "goes unspoken" (Marshall, 2004, 264). While Marshall explores how issues of gender and sexuality play out in the language and plots of children's texts, this research project has carefully analyzed sexuality, race, class, ability, age, and body size. In order to guide the latent content analysis of this research, the following questions from the work of Marshall (2004) have been posed:

1) What stereotypical or non-stereotypical traits arise? 
2) What is said and what is not said (written)?

3) What is shown and not shown (illustrated)?

Methods of analyzing children's literature for representation of diversity of gender

According to Narahara $(1998,4)$, picture books "define standards for masculine and feminine." An analysis of gender has involved asking what stereotypical or nonstereotypical traits arise, what is said or not said, and what is shown or not shown. This investigation of gender has served to determine if gender stereotypes are evident in the illustrations of a book analyzed. For example, a score of one has been given to texts that contain females portrayed as passive characters, females who are nurturing, or those engaged in housework because of the stereotypes attached to these behaviours. Gender stereotypes are also considered present in a book when characters are represented in gendered attire; these incidents result in a score of one. Furthermore, an investigation of unequal representation of gender has been undertaken. Texts that used more frequent male nouns, pronouns, and possessive pronouns have been given a score of one for containing gender misrepresentation. What is omitted has also been considered, for example, a lack of female characters in a book has resulted in the score of one. Books with equal representation of gender and gender-neutral images and text have been allocated a zero for containing no gender stereotypes and a fair representation of males and females.

Methods of analyzing children's literature for representation of diversity of sexuality

In order to determine if a children's book was representative of sexual diversity, a manifest content analysis was used to examine the frequency of heterosexual and 
homosexual relationships. This analysis of sexuality involved a consideration of what stereotypical or non-stereotypical traits arise, what is said or not said, and what is shown or not shown. In contrast, a latent content analysis supplements the original findings with details gained through an investigation of the underlying meaning of each book. The representations of same sex relationships in the text and illustrations have been considered in this analysis. A score of zero has been given to texts that represent heterosexual relationships exclusively. Subtle images (such as a framed photo with a mother and father illustrated) have also been scored as zero for representation of heterosexual relationships. In contrast, books with text about homosexual relationships or illustrations depicting same sex relationships have been allocated a one for representation of diverse sexualities. Books analyzed without references to homosexual or heterosexual relationships in the text or illustrations have been allocated as one because they do not represent same sex relationships.

Methods of analyzing children's literature for representation of diversity of race

Scholars (Fox, 2007, Rowell, 2007) have found that most early childhood education programs offer multicultural and multiracial books that reflect people of colour. This analysis of race has involved asking what stereotypical or non-stereotypical traits arise, what has been said or not said, and what has been shown or not shown. This preliminary study has corroborated or challenged these findings by investigating representation of racial diversity. Using latent content analysis, texts and illustrations have been explored in order to locate characters that appear to be racially or culturally diverse. Any depiction or mention of a child who is not Caucasian in the text of a book or in the illustration has garnered a score of one. In contrast, a failure to include culturally or racially diverse 
characters has earned a score of zero. Likewise, books without human or anthromorphed animal characters have received a score of zero for not representing diversity in race.

\section{Methods of analyzing children's literature for representation of diversity of class}

Class has been examined in this study by seeking to locate books depicting classes outside of middle or upper socio-economic statuses in the illustrations or text. This analysis of class has involved asking what stereotypical or non-stereotypical traits arise, what is said or not said, and what is shown or not shown. Representation of lower class families has been allocated a one for portrayal of diverse classes. In this examination of settings or characters in a variety of social or economic classes, books have been examined for illustrations or written descriptions of apartment buildings, inner-city dwellings, or evidence of financial restrictions. Books that failed to represent characters living in a lower class socio-economic setting have received a score of zero.

Methods of analyzing children's literature for representation of diversity of size

According to Mullen and Shield (2004), there is no internationally recognized definition of childhood obesity (as cited by Su, 2008). While the World Health Organization (2008) deems a body mass index (BMI) over 30 as obese, this study has simply looked for body shapes that are larger than the average thin characters typically depicted in media. This analysis of body size has involved asking what stereotypical or nonstereotypical traits arise, what is said or not said, and what is shown or not shown. Characters whose weight is above average, appear unfit, or are larger than their peers have been allocated a score of one to indicate diversity of body size. Similarly, texts that describe larger characters have received a score of one for representing diverse body sizes. Those 
texts that do not represent larger characters have been allocated a zero for omission of characters who are overweight. Books without human or personified animal characters have also been appointed a score of zero, as weight has not been represented.

\section{Methods of analyzing children's literature for representation of diversity of age}

Scholars (Fillmer, 1983, Taylor, 1977) have found that children's literature delivers a limited and stereotypical portrayal of old age resulting in an inaccurate perception of elderly people as inactive, lonely, and unproductive. Although an international age for old age or elderly people does not exist, generally it is felt that 60 years of age older is considered elderly, as it is the age that pension benefits begin. This study has therefore investigated the representation of individuals who appear to be 60 years of age and older. This analysis of age has involved asking what stereotypical or non-stereotypical traits arise, what is said or not said, and what is shown or not shown. Text and illustrations have been examined in an attempt to locate any underlying messages about age. A consideration of the age of the characters in the books being studied in this project has determined whether or not elderly people are represented. A one has been allocated in instances where books contain characters that appear older than 60 , and a zero has been applied to texts that lack a representation of elderly people.

\section{Methods of analyzing children's literature for representation of diversity of ability}

According to Kaiser (2007) and Matthew and Clow (2007), depictions of characters that have one or more physical or mental challenges are rare. This study has examined 109 books in an attempt to identify characters with disabilities. Illustrations and texts have been examined for wheel chairs, assistive devices such as a walking cane, hearing aides, and 
eyeglasses. Representations of diverse abilities have been allocated a one. Books discussing mental health issues have also been given a one for representing diversity of ability. In contrast, all books that fail to represent diversity of ability have scored zero for each category measured.

\section{Queer theory qualitative analysis instruments}

To elaborate upon the second question of this research project, queer theory will be used as an alternate method of exploring representation of diversity in children's literature. Research utilizing queer theory that explicitly examines diversity in children's literature has not been located; however, it would appear as though the few studies using this framework have provided in depth analyses of one or two forms of media (Lester, 2007, Slagle, 2003). A key concept in queer theory is intersectionality which was developed in response to problems of exclusion and is defined as a way to examine intersecting sources of disadvantage (Johnson, 2009). Because intersectionality seeks to eliminate competition among oppressed groups (Johnson, 2009), an examination of two titles using queer theory has been undertaken.

According to Slagle, the goals of queer theory are in line with poststructuralism, in that queer critics also challenge notions of identity as essential by viewing identity as "fractured and individual" $(2003,130)$. Queer theorists concern themselves with sexuality, more specifically with heteronormativity, by making sexuality visible and critically investigating issues considered "private" and "personal" (Slagle, 2003, 130). This preliminary research study is therefore supplemented by a thorough investigation of two book titles to provide a queer critique that challenges the "essential nature of identities" (Slagle, 2003, 130). The stated goal of Slagle $(2003,131)$ is to "provide a model for such a 
critical approach" therefore this approach to research, informed by queer theory has been used to compose a thoughtful critique of And Tango Makes Three (Parnell, Richardson, Cole, 2005) and Olivia and the Missing Toy (Falconer, 2003). These titles were chosen because each provides ample opportunity to explore issues of gender, sexuality, race, class, ability, age, and body size.

Through an examination of artifacts, queer theorists "challenge the notion of a static, essential, or natural identity" while acknowledging and celebrating difference (Slagle, 2003, 133). The model framework provided by Slagle has informed this preliminary research study using a queer lens to investigate representation of diversity. Two books have been investigated with the following questions posed as an instrument to guide analysis:

1) Does this book represent sexuality as private and personal?

2) Does this book celebrate difference?

3) Does this book perpetuate heteronormativity by locating heterosexuality as "normal"?

4) Does this book challenge essentialism?

This queer critique has considered whether or not a counting method is adequate to examine representations of diversity in children's literature. It has also served to answer this research project's second question which seeks an alternate method of exploring representation of diversity in children's literature. This section of the research informed by queer theory has investigated two books for representations of heteronormativity.

\section{Validity \& Reliability}


Convenience sampling is a simple process, but has the disadvantage of having "very weak external validity" and is likely to be biased (Trochim, 2001, 59). An additional flaw is that it is difficult to gain evidence that the data collected is representative of what is being studied (Babbie \& Benaquisto, 2002). As convenience sampling suited the time restrictions of this preliminary research project, it was thought to be an appropriate choice for this study. According to Reinharz (1983) validity criteria of feminist science are "completeness, plausibility... [and] understanding" but not replicability (as cited by Gorelick, 1996, 26). Manifest content analysis involves investigation of visible surface content and is deemed reliable in coding and measuring research data. According to Babbie and Benaquisto (2002) manifest content analysis compromises validity because measuring text and illustration by counting the number of times a word appears does not necessarily produce accurate results. In contrast, latent content analysis provides an in depth valid interpretation of data; however, reliability is compromised due to the risk of inconsistency when coding and interpreting the data (Babbie \& Benaquisto, 2002). Therefore, according to Babbie and Benaquisto (2002), combining latent and manifest content analysis is ideal in order to ensure validity and reliability. The validity and reliability of the research is strengthened in this research project by manifest content analysis that measures visible content and latent content analysis which explores the underlying meaning of each book. Qualitative research informed by queer theory has also supplemented this project.

\section{Conclusion}

In an effort to outline the methodology used in this project, this chapter has provided details about ethics, data collection, instruments, and validity and reliability. Furthermore, key terms have been identified and defined; the initial study has been outlined articulating 
how sexuality was examined using a counting manifest content analysis; feminist poststructural research that recognizes the interconnectedness of identity has been described including strategies to examine representation of diversity in children's literature; the role of feminist poststructural research in an examination of alternative methods of exploring social issues has been illustrated; and, research informed by queer theory has been described and outlined to capture a diverse way of investigating social issues in children's literature. Answering the research questions with the aforementioned measures has been achieved and subsequent chapters have identified the findings produced from this research project. 


\section{Chapter 4}

Findings

During the research process experiences inevitably shift and change resulting in negotiating, and reevaluation (Clandinin \& Connelly, 2000). Significant changes have occurred over the course of this preliminary research project. After the process of collecting and analyzing the manifest content analysis data, a need for a paradigm shift became evident. Although the latent content analysis seemed to be adequate, upon further analysis of particular books, it became evident that more sophisticated criteria for analysis would be beneficial. This chapter will discuss the findings of the manifest content analysis that measured the frequency of representation of heterosexuality in children's literature. The latent content analysis findings that investigate representation of gender, sexuality, race, class, ability, age, and body size will follow. Findings from a qualitative exploration of two selected book titles have also be considered in this evaluation. The following three main research questions have been answered prior to discussing the limitations of each section of the study:

1) Does children's literature currently used in early childhood classrooms reflect diversity of gender, sexuality, race, class, ability, age, and body size?

2) Is the counting method adequate to examine representation of diversity in children's literature?

3) What are alternate methods of exploring representation of diversity in children's literature? 
The last question of this research project, which asks how representation of diversity in children's literature can be brought to the attention of early childhood educators to promote deliberate book selection, will be addressed in the next chapter.

The following section outlines the findings from the manifest and latent content analyses of all of the books studied. Qualitative data gathered from studying two titles, And Tango Makes Three (Parnell, Richardson, Cole, 2005) and Olivia and the Missing Toy (Falconer, 2003) has been analyzed in this chapter. In addition to the number of books analyzed, the year of publication of books has been discussed.

\section{Number of books analyzed}

A total of 109 books were analyzed for this research project. Sixty-nine of the books were gathered from the bookshelves of four daycare classrooms. The early childhood education teams from each of the four classrooms provided ten books per class for a total of 40 books. The bookshelf in the infant classroom contained 16 books. Of the books analyzed, $23.9 \%$ were collected from the infant program from a combination of those on the bookshelf and those collected from the ECE team. The preschool class studied contributed $35.8 \%$ of the books to this study with ten books from the team of preschool ECEs and 29 books analyzed from the preschool bookshelf. Both the toddler and kindergarten programs had 12 books collected from their classrooms. Combined with the ten books provided by the teams of ECEs, the toddler class and kindergarten class each had a total of 22 books analyzed. The following graph outlines the number of books analyzed from each setting. 


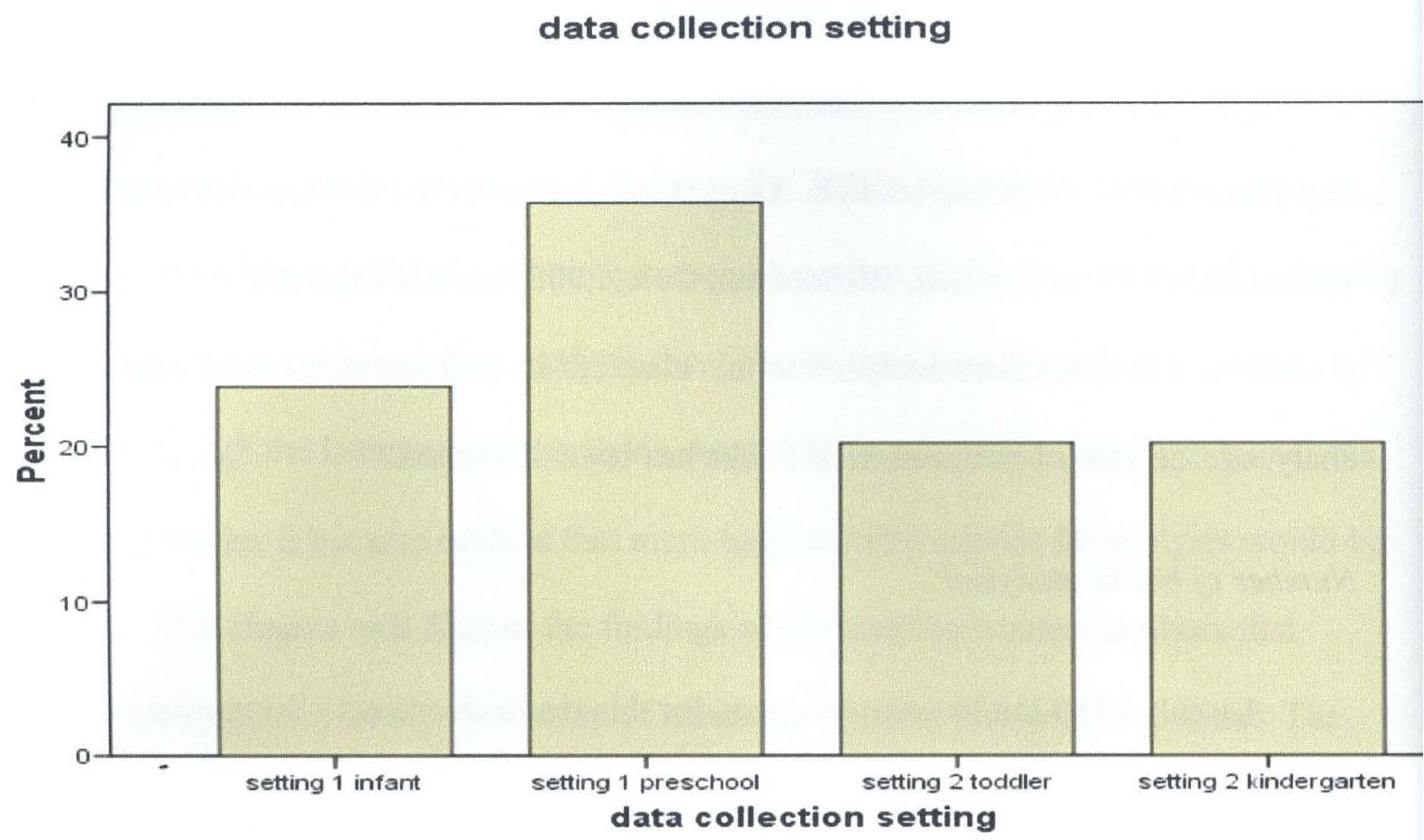

Year of publication of books

The books collected in each of the four classes contained a variety of children's literature ranging from classics published in the 1940s to more modern texts published in the year the data was collected, 2008. It is worth noting that 13 of the books analyzed were published before 1970, the year which marked the shift in publishing practices to consider such things as race and gender in children's literature (Paterson \& Lach, 1990). Just 3.6\% of the titles used in this research study were published in the $1970 \mathrm{~s}$, whereas $12.8 \%$ of the books were published in the $1980 \mathrm{~s}$, and $27.6 \%$ were published in the $1990 \mathrm{~s}$. Lastly, $35 \%$ of the newer releases studied were published between 2000 and 2008. The mean year of publication is 1992.5, the median year of publication is 1996, and the mode year of 
publication is 1999. The following graph illustrates the year of publication for all of the books studied.

Table 2- graph 2 illustrating the percentage of books analyzed in each year.

year of publication

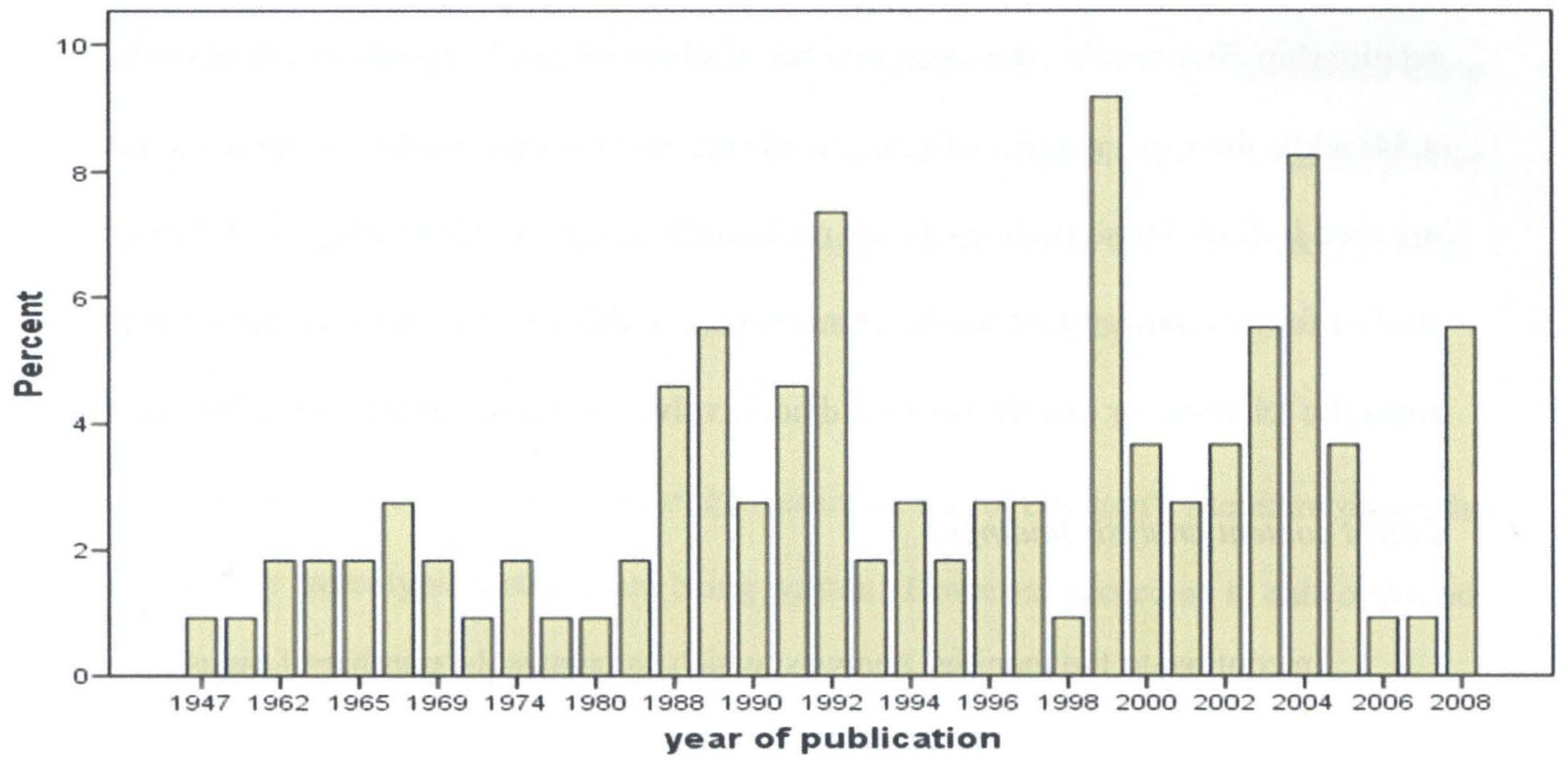

Manifest content analysis findings

In order to measure the frequency of representation of heterosexuality in children's literature, a counting method was used. Children's texts were reviewed with the understanding that if heterosexuality was represented in text or illustrations, that book might be deemed heteronormative. By examining what was said and shown in the various texts, findings reveal that many of the books studied depict heterosexuality as 'normal.' Day 
(2000) defines heteronormativity as an assumption that the majority of people are heterosexual and this sexual identity is perceived as superior. None of the books explicitly state that heterosexuality is 'normal,' nor that it is superior; however, the books almost exclusively represent heterosexuality. In fact, $40 \%$ of the books analyzed contained illustrations of heterosexual characters on one or more occasion. More specifically, 32 of the 109 titles contained illustrations that could be deemed heteronormative. Likewise, $30 \%$ of the books included text that involves terms implying the existence of a heterosexual relationship. Statistically, the mean number of illustrations of opposite sex relationships is 4.84; while the mean number of times words meaning mother and father or their synonyms are used is 2.48 . These findings do not necessarily imply that the remainder of the books studied for this project were not heteronormative; rather that they may not have represented romantic relations, or that the books did not involve human or personified animal characters.

\section{Latent content analysis findings}

In contrast to the manifest analysis, which calculates the number of times heterosexual relationships are portrayed, the latent content analysis was conducted to discern the underlying meaning of text and illustrations in order to understand what is not shown or written in books. In the following sections, the findings from a latent content analysis performed for this study are described in relation to the representation of gender, sexuality, race, class, ability, age, and body size in the books studied.

\section{Representation of diversity of gender}

In order to investigate the representation of diversity of gender a variety of children's texts were studied by considering what stereotypical or non-stereotypical traits arise in the 
texts, what is said or not said, and what is shown or not shown. The results from this investigation of gender corroborate with the findings of other scholars exploring issues of gender in children's literature (Anderson \& Hamilton, 2005, Wharton, 2005, Toshiko, 2000, Allard \& Cooper, 1997, Narahara, 1998). That is that gender stereotypes depicting females in gendered attire, females participating in gender stereotypical activities, and the general underrepresentation of female characters is prevalent in books available in ECE settings today. This is particularly evident in the illustrations of the children's literature analyzed for this research. In $56.9 \%$ of the books studied, illustrated characters were represented using gender stereotypes. In 62 of the 109 books analyzed, girls were illustrated wearing gender specific clothing (such as dresses, and bows), engaging in actions that are stereotypical to females (such as playing with dolls, or playing with dishes), or they are simply underrepresented.

Data analysis of representation of gender in the text of children's literature shows that fewer gender stereotypical stories are being written. However, according to data collected for this study, $26.6 \%$ of books analyzed were written without a regard for diversity of gender and therefore could be considered sexist. In some instances books used what many now be deemed inappropriate language such as “fireman" (Don't Wake Up Mamma, Christelow, 1992), and "lady" (Goodnight Moon, Wise Brown, 1947), while other books were more blatant. For example, in the book A Letter to a King Anderson (1991) wrote, "If only I had a son, he would have done something to help me...my daughters only know how to weep." The language used in the book Things I Like About My Grandma is also passively sexist; author Francis Haskins (1992) writes that grandma does "boy things too," the implication being that it is odd or at least notable that women would be interested in 
activities deemed appropriate only for boys. Overall, 80 of the 109 books studied did not represent gender in a sexist way in the text and 47 of the 109 books did not have sexist illustrations.

Representation of diversity of sexuality

In order to determine if a given children's book is representative of sexual diversity, a manifest content analysis was used to examine the frequency of heterosexual and homosexual relationships. This analysis of sexuality involved asking what stereotypical or non-stereotypical traits arise, what is said or not said, and what is shown or not shown. Latent content analysis has supplemented the original findings with details gained through an investigation of the underlying meaning of each book. One of the criterion that has been considered is the existence of representations of same sex relationships in both text and illustrations. Those books analyzed for this study that did not include any references to homosexual or heterosexual relationships have been allocated a score of zero. According to the findings, $98.2 \%$ of the books in this research study received a score of zero for containing no relationships or exclusive representation of heterosexual relationships. In an analysis of the book No, David! (Shannon, 1998), subtle images of a framed photo containing a mother and father resulted in a score of zero for its representation of a heterosexual relationship (see figure 1). 
Figure 1 - illustration 1 demonstrating subtle representation of heterosexuality (photo of family on top of television) from the book $N o$, David! by David Shannon, 1998.

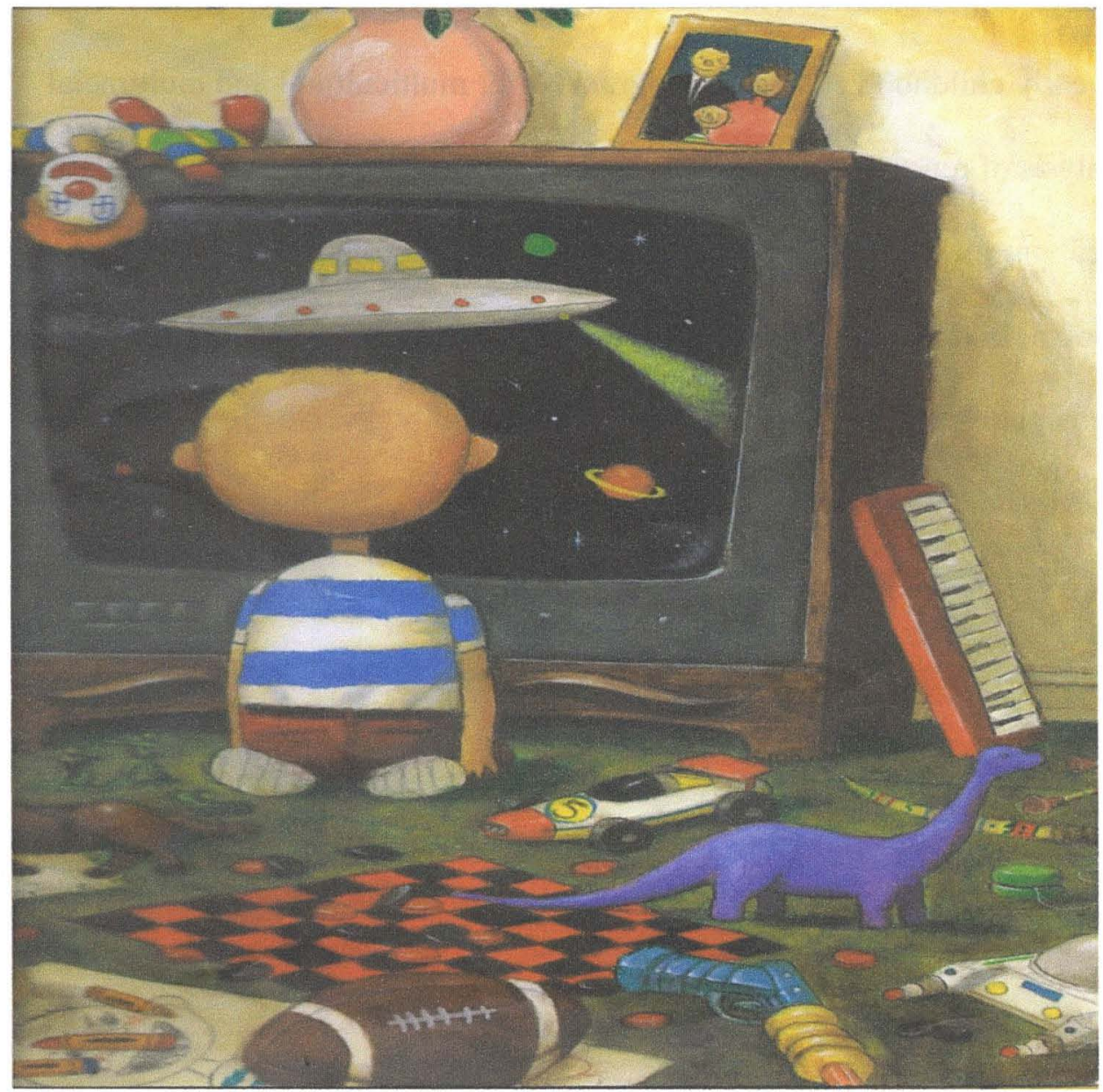

This illustration (figure 1) portrays stereotypically male activities (such as playing with a car, a football, a dinosaur, and a gun), and the framed photo accentuates a heteronormative message that to be a male means to be with a female partner. This message was typical throughout the books studied as just $1.8 \%$ of the books received a score of one for representing homosexual relationships. It was evident that the books tended to reflect the latent inclination of many societies and persons to subordinate members of the queer community through exclusion. 
The findings of this study corroborate with Fox (2007) and Rowell (2007) who found that most early childhood education programs offer multicultural and multiracial books. This analysis of representations of race in children's literature has involved asking what stereotypical or non-stereotypical traits arise, what is said or not said, and what is shown or not shown. In this latent content analysis, text and illustrations were studied in order to locate characters that appear to be racially or culturally diverse. In 41 instances, non-Caucasian characters were located in the text of a book or in an illustration, which resulted in a score of one for $37.6 \%$ of the books. In contrast, a failure to include culturally or racially diverse characters occurred in $62.4 \%$ of the books studied. Rowell's (2007) assertion that most early childhood education programs offer multicultural books is corroborated by the findings of this study. 


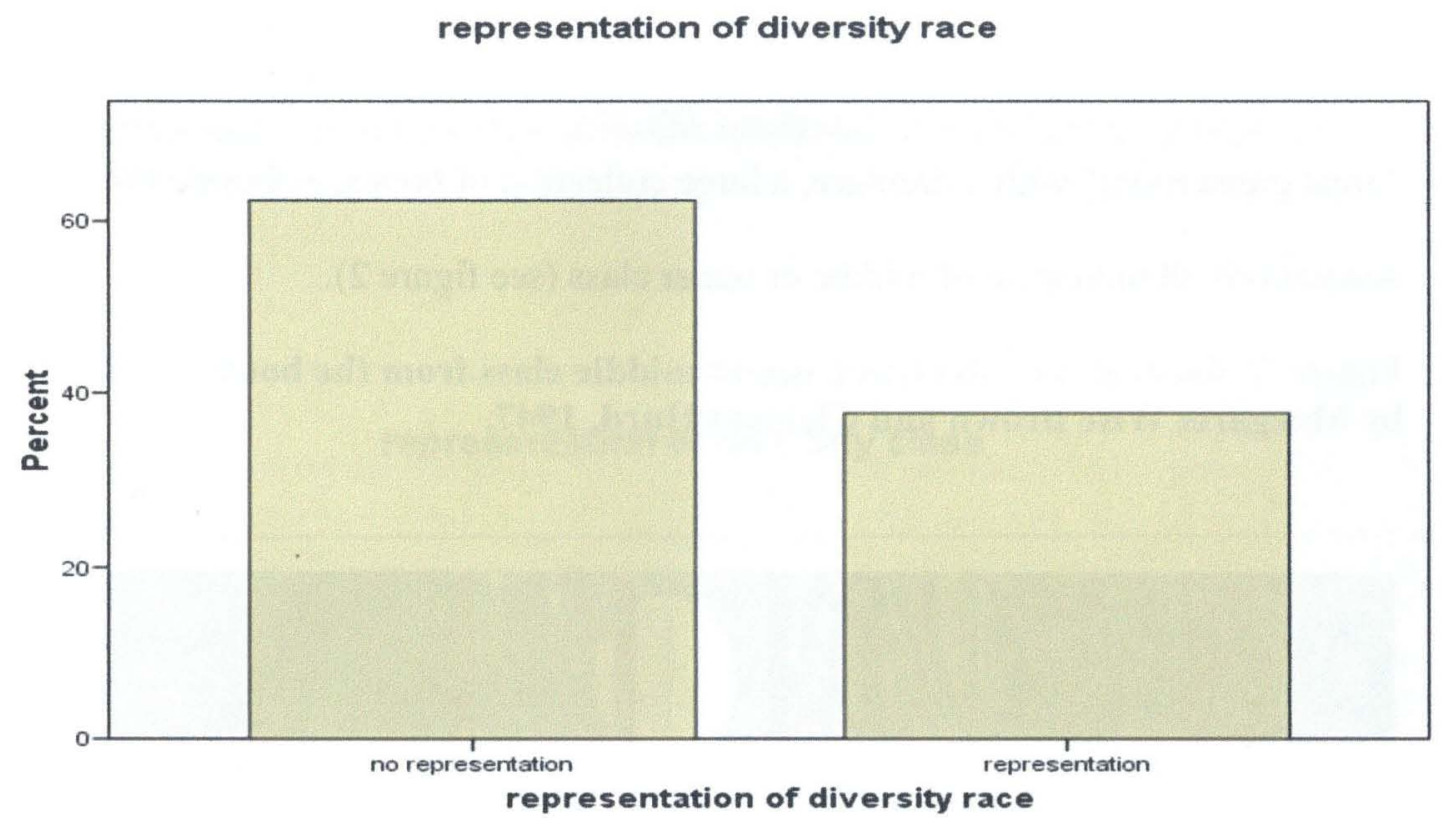

Representation of diversity of class

The content of children's literature was studied in order to determine if a variety of social classes are included in these texts. From the results of this study, it can be determined that upper and middle classes are predominantly featured in children's books. These results were obtained through studying illustrations and texts of books for a depiction of classes outside of the middle to upper range; some startling results were found. By asking what stereotypical or non-stereotypical traits have arisen, what is said or not said, and what is shown or not shown, it was found that there is a general lack of attention to class in children's literature. Throughout the texts studied for representations of a variety of social or economic classes (other than upper middle, or middle class) there was seldom any reference to or indication of characters living in apartment buildings, inner-city dwellings, or any 
other evidence of financial restrictions. Representations of lower class families indicated by a portrayal of diverse classes, occurred on just five occasions. Goodnight Moon (Wise Brown, Hurd, 1947) is one example of the $95.4 \%$ of books analyzed that failed to represent characters living in a lower class. Goodnight Moon (Wise Brown, Hurd, 1947) portrays an "great green room" with a fireplace, a large collection of books, elaborate furnishings and decorations all indicative of middle or upper class (see figure 2).

Figure 2 -illustration 2 depicting upper middle class from the book Goodnight Moon by Margaret Wise Brown and Clement Hurd, 1947.

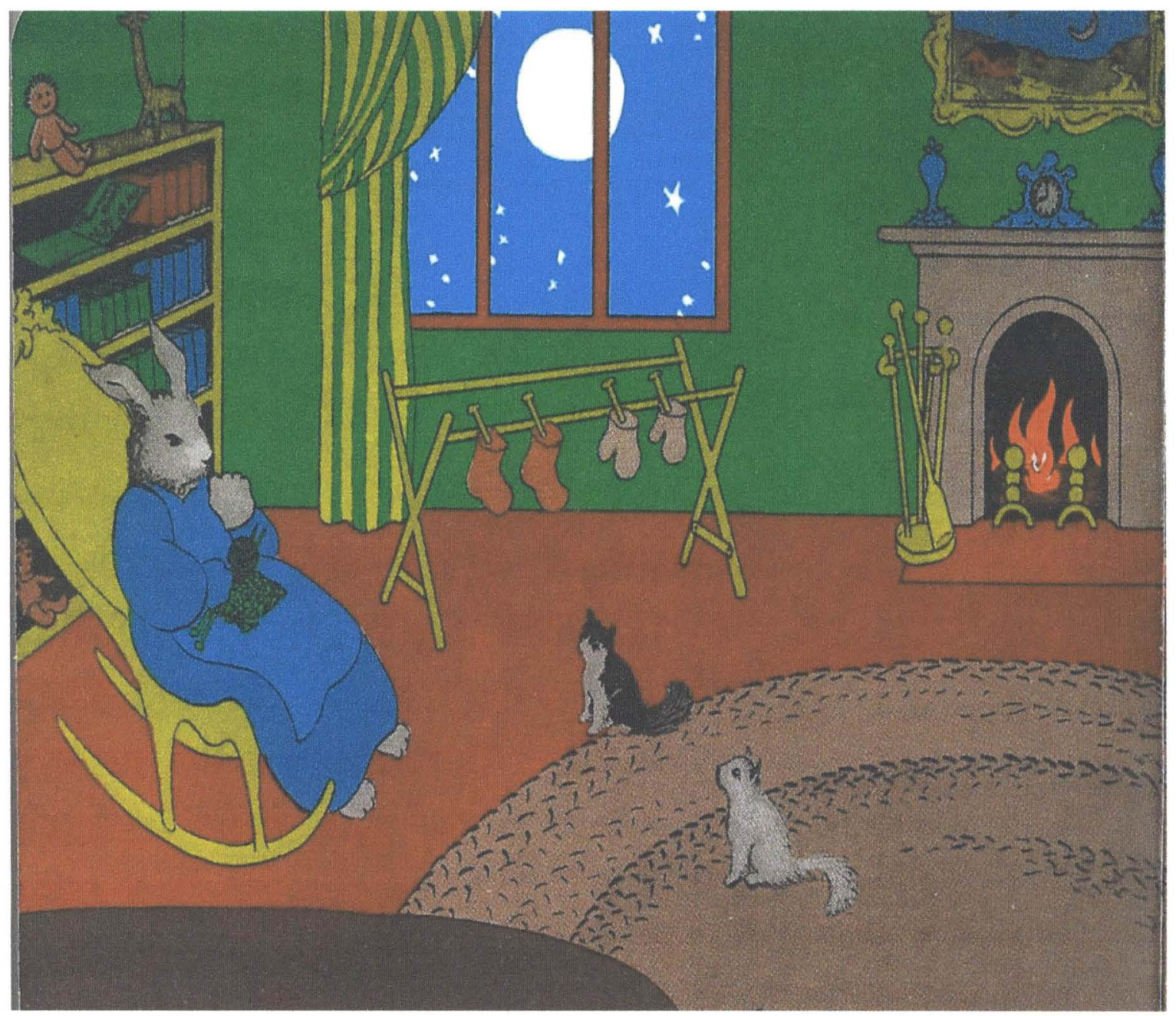


In fact, representations of lower socio-economic classes only occurred within a meager $4.6 \%$ of the books involved in this study. The following graph clearly illustrates the negligence of authors, illustrators, and publishers to include issues of class in children's literature.

Table 4- graph 4 illustrating the percentage of books analyzed that represented diversity of class and the percentage of books analyzed that do not represent diversity of class.

representation of diversity class

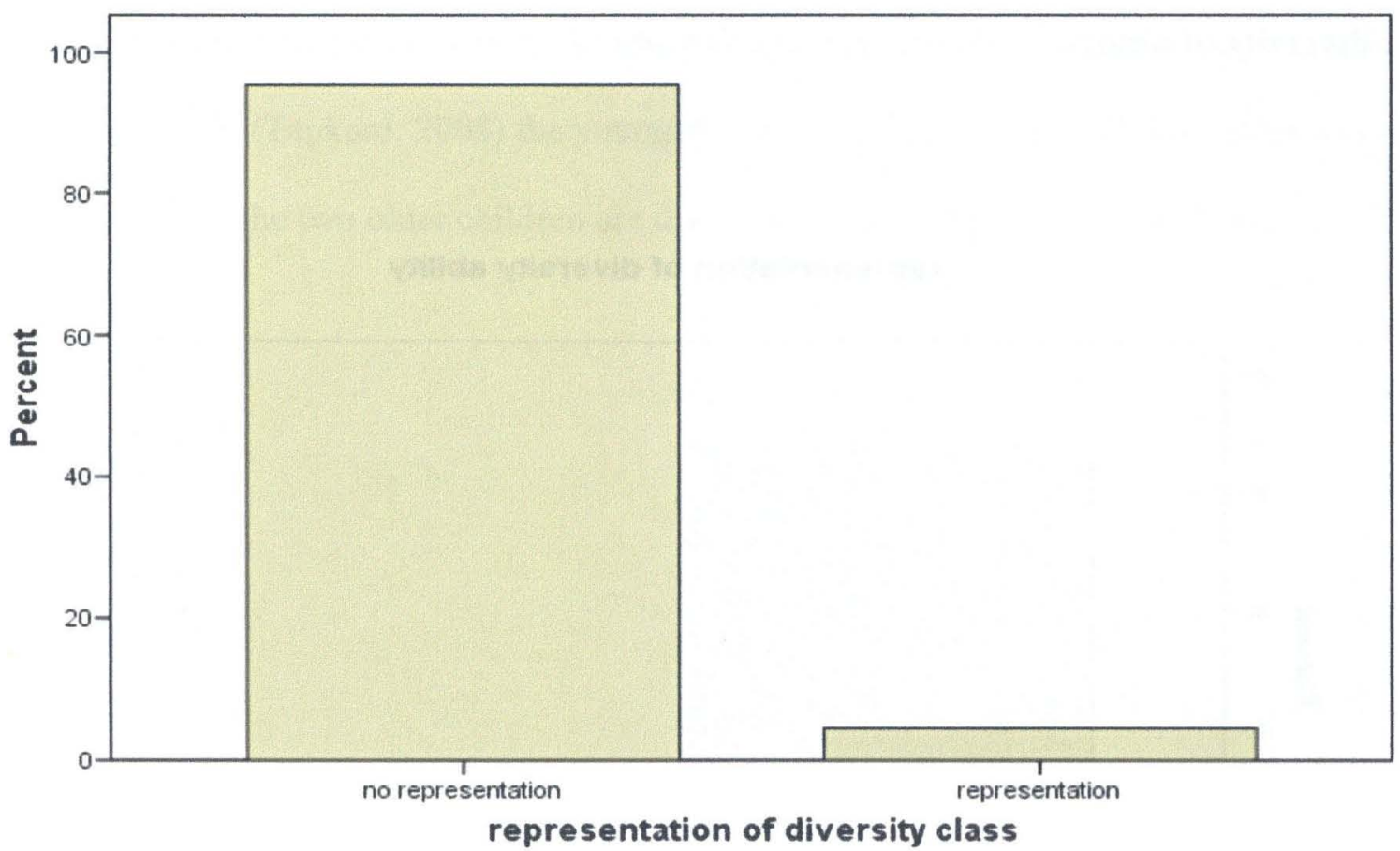

Representation of diversity of abilities

The results of this study have corroborated the findings of Kaiser (2007), and Matthew and Clow (2007) who claim that depictions of characters that have one or more physical or mental challenge are difficult to locate in children's books. In this examination of children's texts for characters with disabilities, only $12.8 \%$ of books analyzed represented 
diverse abilities. Moreover, in each circumstance where representation of ability was noted, it was due to the inclusion of eyewear on a character, which occurred in 14 books. Although illustrations and text have been examined for wheel chairs, assistive devices such as a walking cane, and hearing aids, only eyeglasses were represented. In comparison, $87.2 \%$ of the books analyzed failed to represent diversity of ability. Had eyewear been excluded as suitable criteria to render a book representative of diverse abilities, the percentage of representation of diverse abilities would not be $12.8 \%$ but a meager $1.8 \%$.

Table 5-graph 5 illustrating the percentage of books analyzed that represented diversity of ability and the percentage of books analyzed that did not represent diversity of ability.

representation of diversity ability

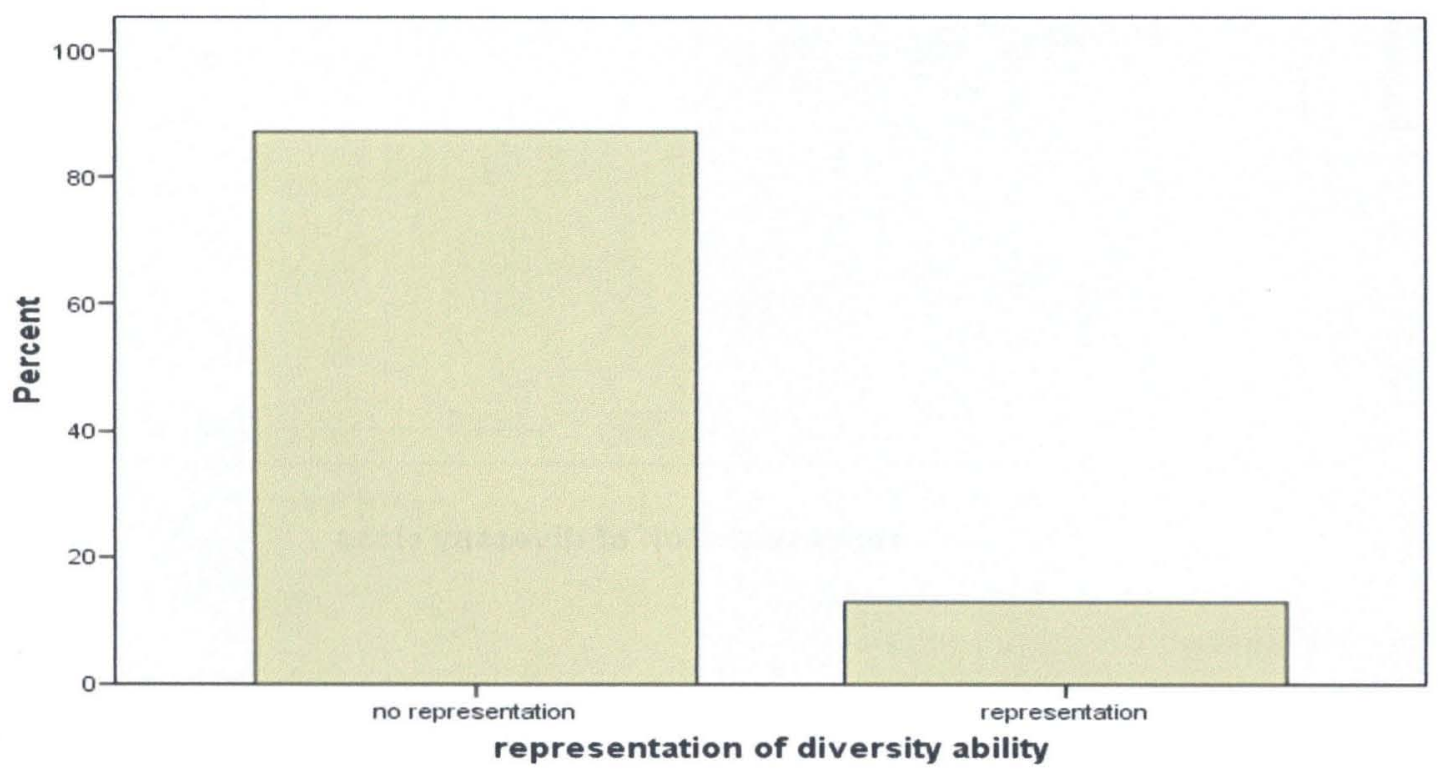

Representation of diversity of age

An investigation of representation of diversity of age revealed that fewer than $20 \%$ of books examined contained images of characters who appear to be sixty years of age and 
older. In fact just 14 of the 109 books included grandparents in the text and illustrations accounting for $12.8 \%$ of books. In an attempt to locate the underlying meaning of the texts studied, each book was carefully examined for messages about age. This study revealed that all representation of elderly people depicted grandparents who appear to be 60 or older, while parents generally appeared in their $20 \mathrm{~s}$ and $30 \mathrm{~s}$. For example, in the book $\mathrm{Me}$ Hungry! by Jeremy Tankard (2008), despite tired looking eyes, the parents appeared between the age of 20 and 30 years old with no wrinkles or gray hair (see figure 3 ). Furthermore, as is observed throughout the study, characters in children's books are often represented doing what the dominant discourse deems age appropriate. For example, in the book Me Hungry! (Tankard, 2008) the youngest baby is being held; the slightly older child is crawling while the two older children are drawn in a standing position (see figure 3). 
Figure 3- illustration 3 depicting representation of age from the book Me Hungry! By Jeremy Tankard, 2008

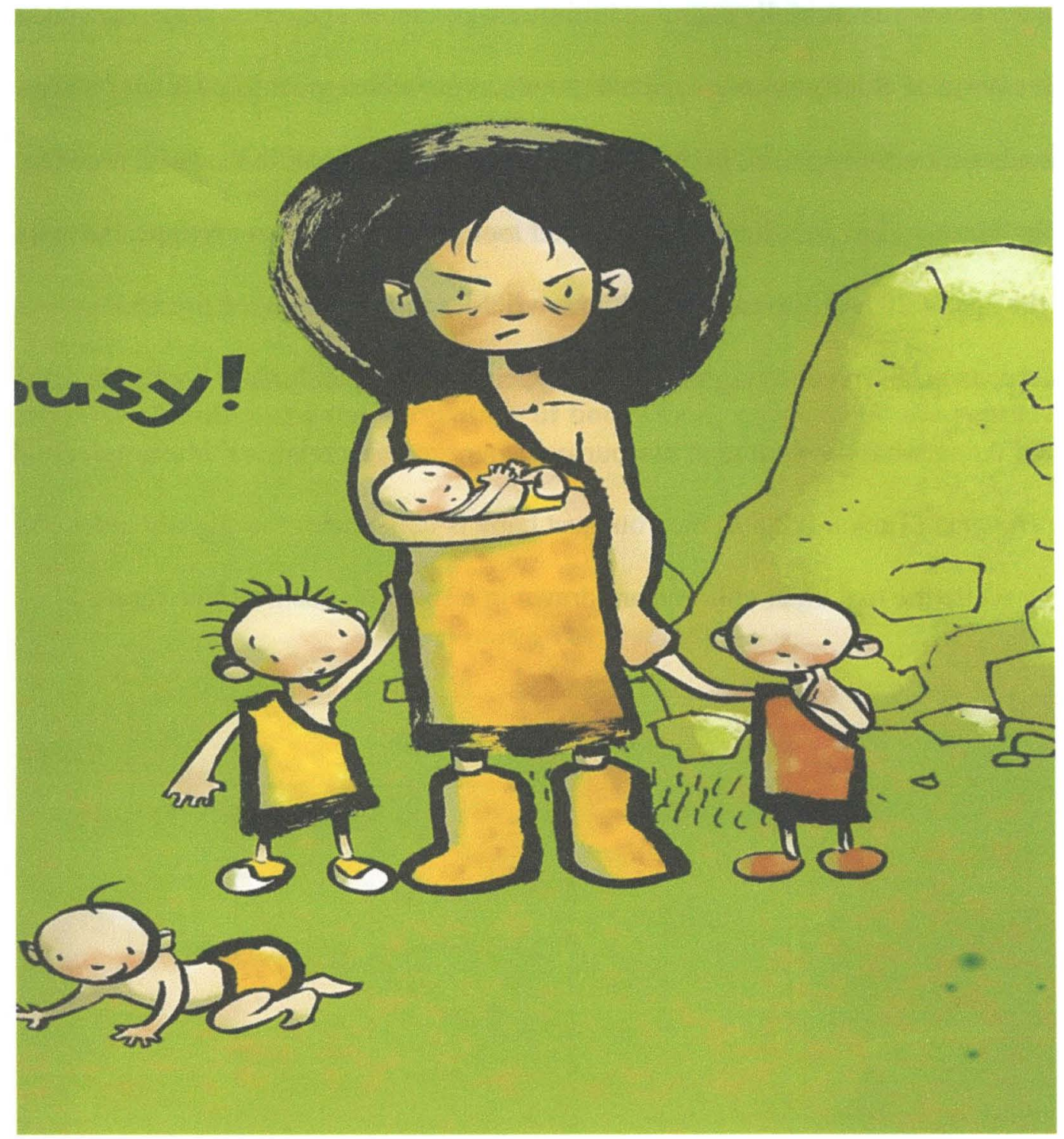

While a variety of ages were depicted in the books examined, teenage, or middle-aged parents were not located. Findings indicated that $87.2 \%$ of the books failed to represent diversity of age therefore implying that they could be considered ageist. 


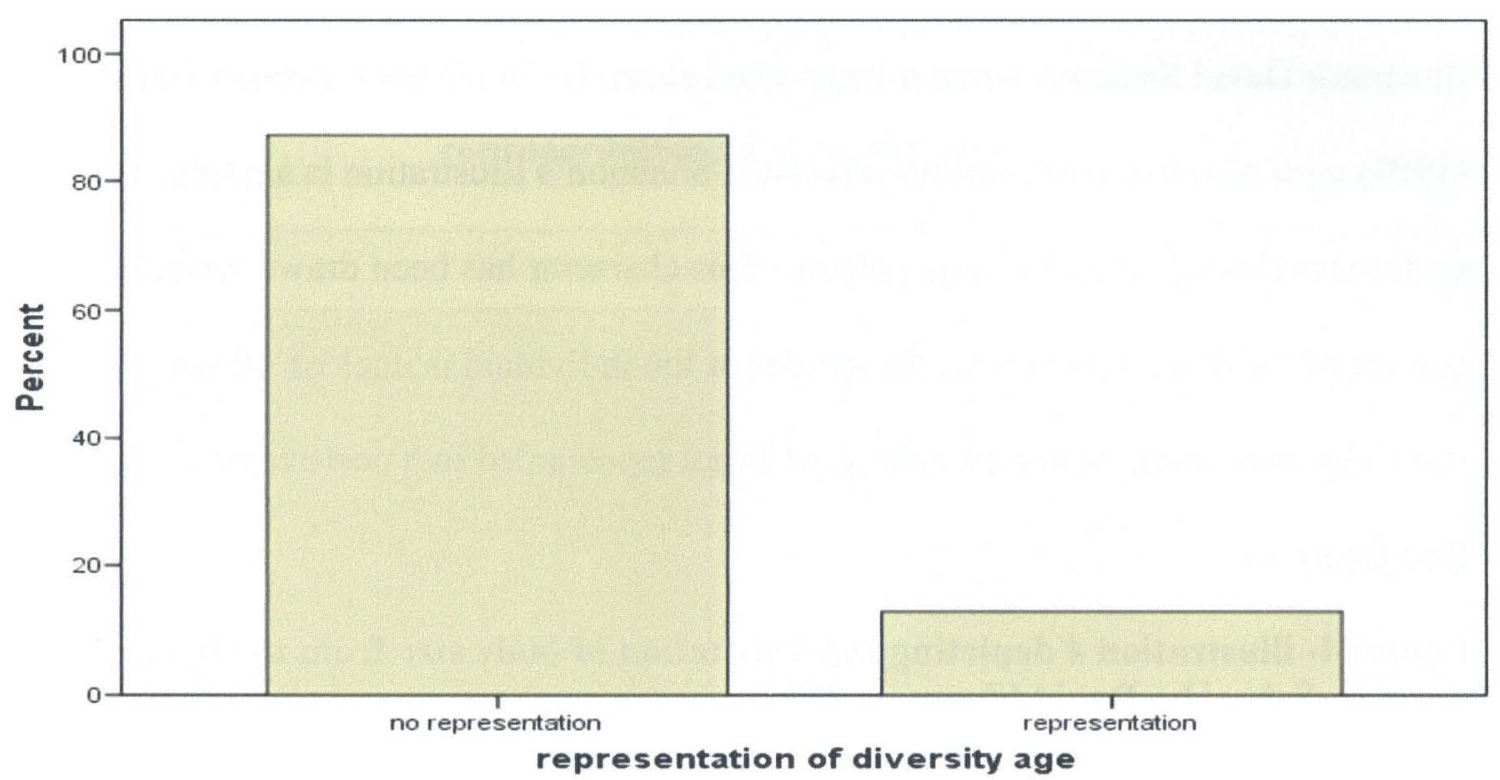

Representation of diversity of body size

This analysis of size has involved asking what stereotypical or non-stereotypical traits arise, what is said or not said, and what is shown or not shown. Characters who weigh more than their peers, appear unfit, or are larger than average, or text using words such as fat or its synonyms have been allocated a score of one in just seven instances. Books that did not include any representations of large characters have been allocated a zero for this omission. Books without humans or anthropomorphism have also been allocated a score of zero. Findings reveal that diversity of body size occurred $6.4 \%$ of the time in contrast with the failure to represent large characters at $93.6 \%$ in the books studied. In instances where 
diversity of body size is represented, above-average-sized characters were often older woman as in Mrs. Wishy Washy (Cowley, Fuller, 1980). Author and illustrator Sandra Boynton published one of many books depicting characters of various body sizes.

Opposites is one title by Boynton (1984), which was part of this study, that represents various body shapes and sizes free of negative stereotypes. Unlike Boynton, author and illustrator David Shannon wrote a large-sized character in his book David Goes To School (1999) with negative connotations attached. Shannon's illustration is a glimpse of the midsection and breast area of a large person. This character has been drawn wearing a soiled apron and hairy arms; however, the gender of the individual is unclear. What is clear is that this large, slouching, unkempt individual is not represented in a positive or attractive manner (see figure 4).

Figure 4- illustration 4 depicting representation of body size from the book David Goes To School by David Shannon, 1998.

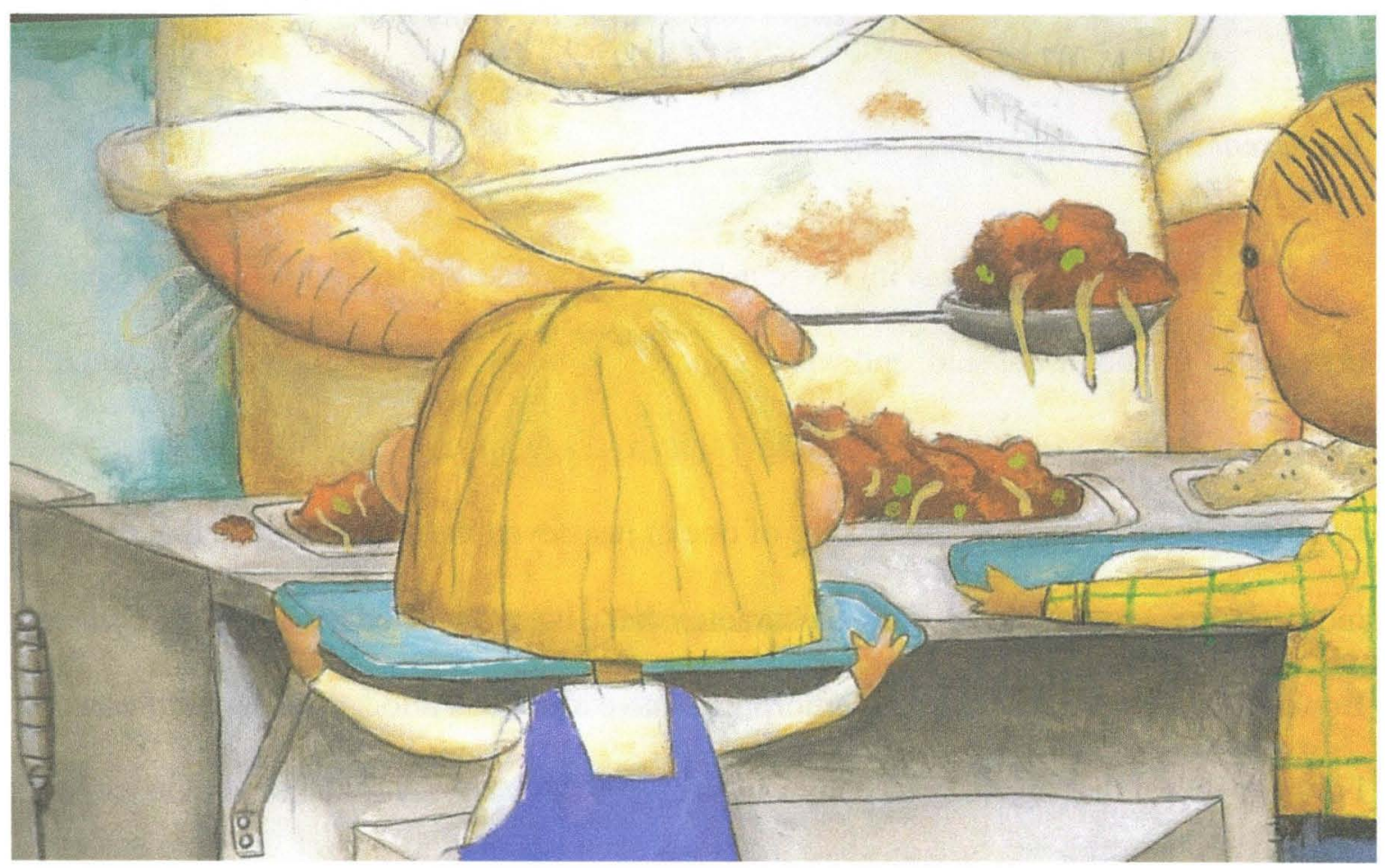


It can be discerned from the preliminary study analyzing representation of body size of characters that few images or mention of larger people have been included in children's literature. Therefore these texts can be considered as contributing to sizeism.

\section{Table 7- graph 7 illustrating the percentage of books analyzed that represented} diversity of body size and the percentage of books analyzed that do not represent diversity of body size.

\section{representation of diversity size}

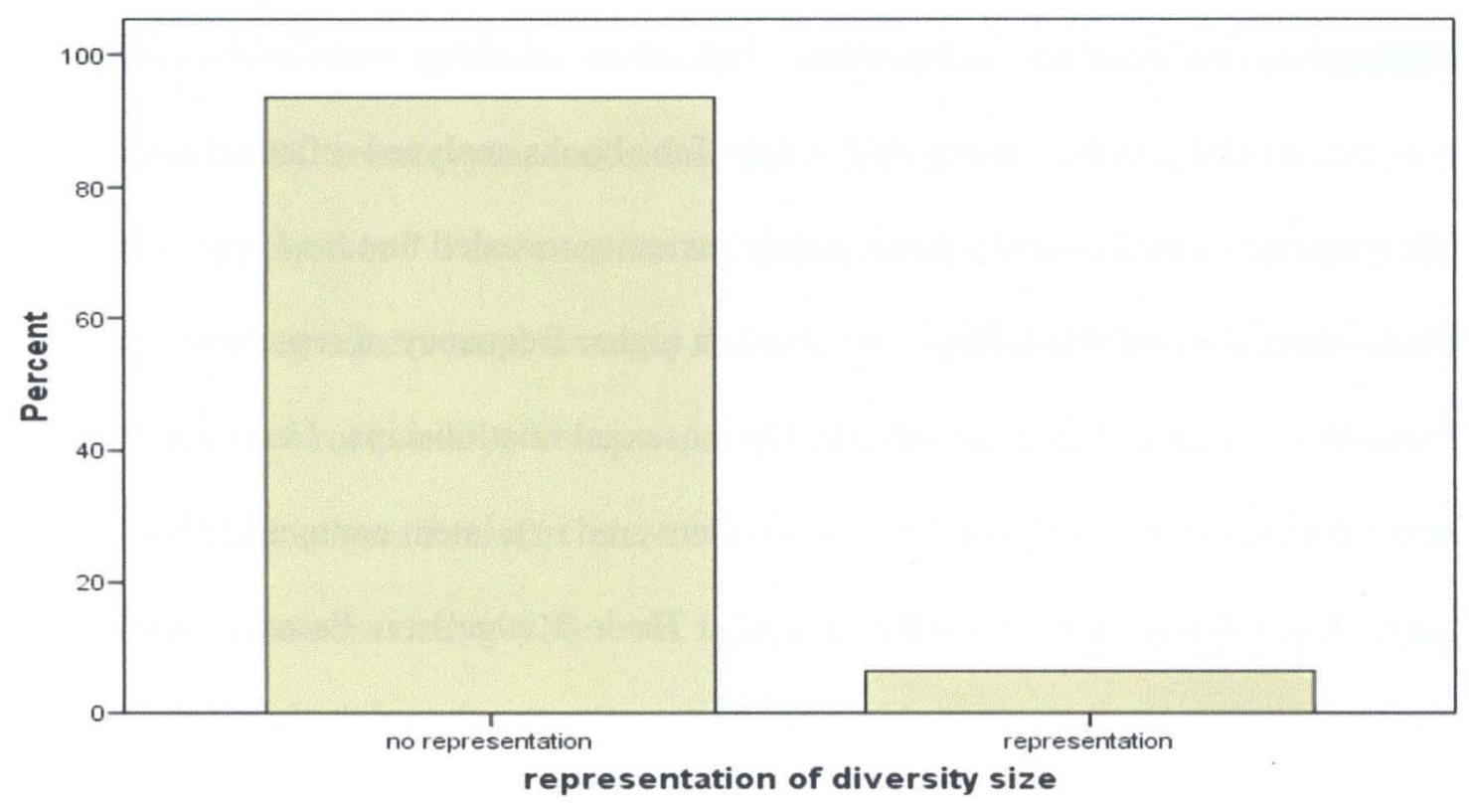

Qualitative Queer Theory Analysis of Two Books

The model framework of Slagle has informed this preliminary research study which uses a queer lens to investigate representation of diversity in the books And Tango Makes Three (Parnell, Richardson, Cole, 2005) and Olivia and the Missing Toy (Falconer, 2003). These two books have been investigated with the following questions posed to guide analysis: 
1) Does this book represent sexuality as private and personal?

2) Does this book celebrate difference?

3) Does this book perpetuate heteronormativity by locating heterosexuality as 'normal'?

4) Does this book challenge essentialism?

Children's books displaying domestic and family settings are an obvious opportunity for gendered discourses (Wharton, 2005) as they are a site for children to learn about relationships and thus heteronormativity. This study's findings in regard to representation of sexual diversity indicated that only $1.8 \%$ of the books analyzed reflected sexual diversity. The manifest content analysis investigating sexuality revealed that And Tango Makes Three (Richardson, Parnell, Cole, 2005) has shown a higher frequency of representation of heterosexual relationships than it does of homosexual relationships. However, representations of diverse sexualities were uncovered in a latent content analysis of the same book. A qualitative look at And Tango Makes Three (Richardson, Parnell, Cole, 2005) about two male penguin partners has served to supplement the original findings of this study.

Queer analysis of And Tango Makes Three

And Tango Makes Three (Richardson, Parnell, Cole, 2005) is based on the true story of two male Chinstrap Penguins named Roy and Silo who live in New York's Central Park Zoo. According the author's note Roy and Silo formed a couple in 1998 and were observed trying to hatch a rock that resembled an egg. When zookeeper Mr. Ramsay realized that Roy and Silo were both male, he gave them an egg to hatch that had belonged to a couple who could not successfully hatch two eggs at once. 
At first glance, this book celebrates difference by representing sexual diversity.

Furthermore, it could be said that this story was written in an effort to expose the public to issues of sexuality through a candid story about the perceived homosexuality of two penguins. For instance, when the zookeeper noticed the male penguins winding their necks around each other, he noted "they must be in love." This tale also identifies Roy and Silo as a couple and tells the reader that the penguins sleep together "every night....just like the other penguin couples" (Richardson, Parnell, Cole, 2005).

However, what is not said in this story is as important as what is said, and according to Tatum $(2000,79)$ "stereotypes, omissions, and distortions all contribute to the development of prejudice." For instance, And Tango Makes Three (Richardson, Parnell, Cole, 2005) may represent sexual diversity, but at the same time this book may also promote the normalcy of heterosexuality. Using a queer lens to deconstruct the book And Tango Makes Three (Richardson, Parnell, Cole, 2005) it became clear that that it fails to label same sex affections as homosexual, gay, lesbian, queer, or same-sex. Wolf $(1998,52)$ asserts that "failure to identify parents as gay" makes the "educational value questionable" and further insists that labels are needed to challenge homophobia. Wolf asserts that a book in which homosexuality is not the focus is refreshing; however, when the issue is dominant, "it tends to seem a problem" rather than just incidental $(1998,53)$. This may be the case in And Tango Makes Three (Richardson, Parnell, Cole, 2005, 6-8):

"Every year at the same time, the girl penguins start noticing the boy penguins. And the boy penguins start noticing the girls. When the right girl and the right boy find each other, they become a couple. Two penguins in the penguin house were a little bit different. One was named Roy, and the other was named Silo. Roy and Silo were both boys. But (bold mine) they did everything together ... 'they must be in love.' 


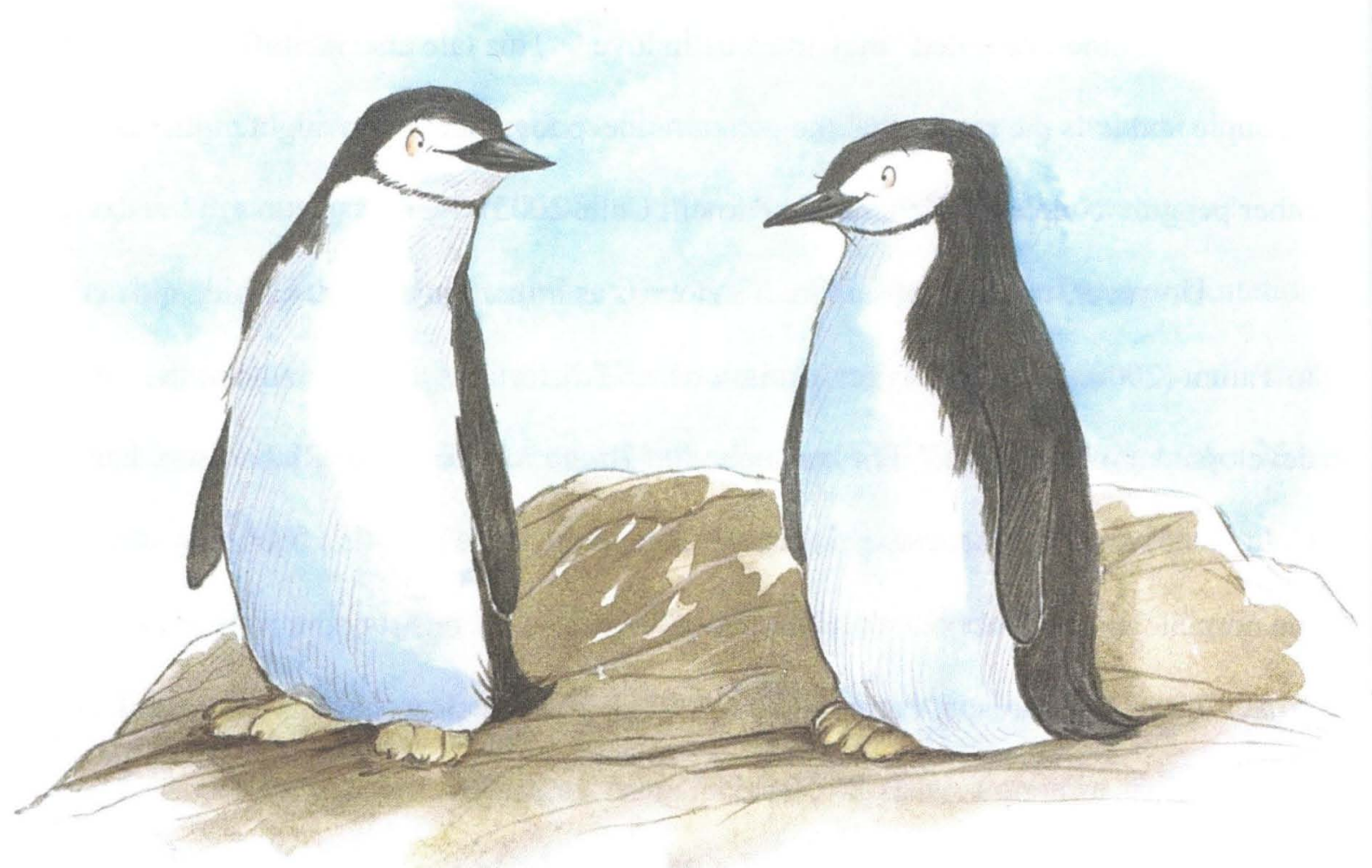

According to Foucault's writings, things that are labeled as 'good' have been socially constructed, and in this context he argues that society has been led to believe that sex should be silenced (1978). One way to guide this queer analysis is through an examination of how a book may perpetuate heteronormativity by locating heterosexuality as "normal." Highlighting the activities of all of the other animals in the zoo accentuates the normalness of heterosexuality. Furthermore, the word "but" implies that same sex 
characters are not normal and therefore labels them as "other." According to Kumashiro $(2002,321)$, the term 'other' refers to "groups that are traditionally marginalized, denigrated, violated" (i.e., Othered) in society (as cited in Rothing, 2008, 257).

This analysis has also called for an investigation of whether or not sexuality is represented as private and personal. According to Britzman (1997), making sex a private affair contributes to notions of heteronormativity by giving it a voice and representation thus rendering it 'normal' and 'natural' (Robinson, 2006, 158). By failing to identify Roy and Silo as gay and making sex private And Tango Makes Three (Richardson, Parnell, Cole, 2005) fails to truly celebrate difference. Robinson explored research that investigated the perceptions and practices of early childhood professionals dealing with gay and lesbian issues (2002). Many of the participants felt sexuality was irrelevant, claiming that sex is a private issue (Robinson, 2002). If we are to respect diversity, individual sexuality is a fundamental aspect of identity and according to Slagle, should not be made private (2003).

Despite the omissions of identifying the male penguins as homosexual and the usage of the word "but" in a key passage in And Tango Makes Three (Richardson, Parnell, Cole, 2005), the intersections of identity appear to have been considered. For example, the visitors of the zoo were various sizes, ages, and cultures, and configurations of families vary. Furthermore, the zookeeper has a photo on his desk of a male, which is a possible suggestion of a same sex relationship (see figure 6). 
Figure 6- illustration 6 depicting the zookeeper, Mr. Gramzay, from the book And Tango Makes Three (Richardson, Parnell, Cole, 2005).

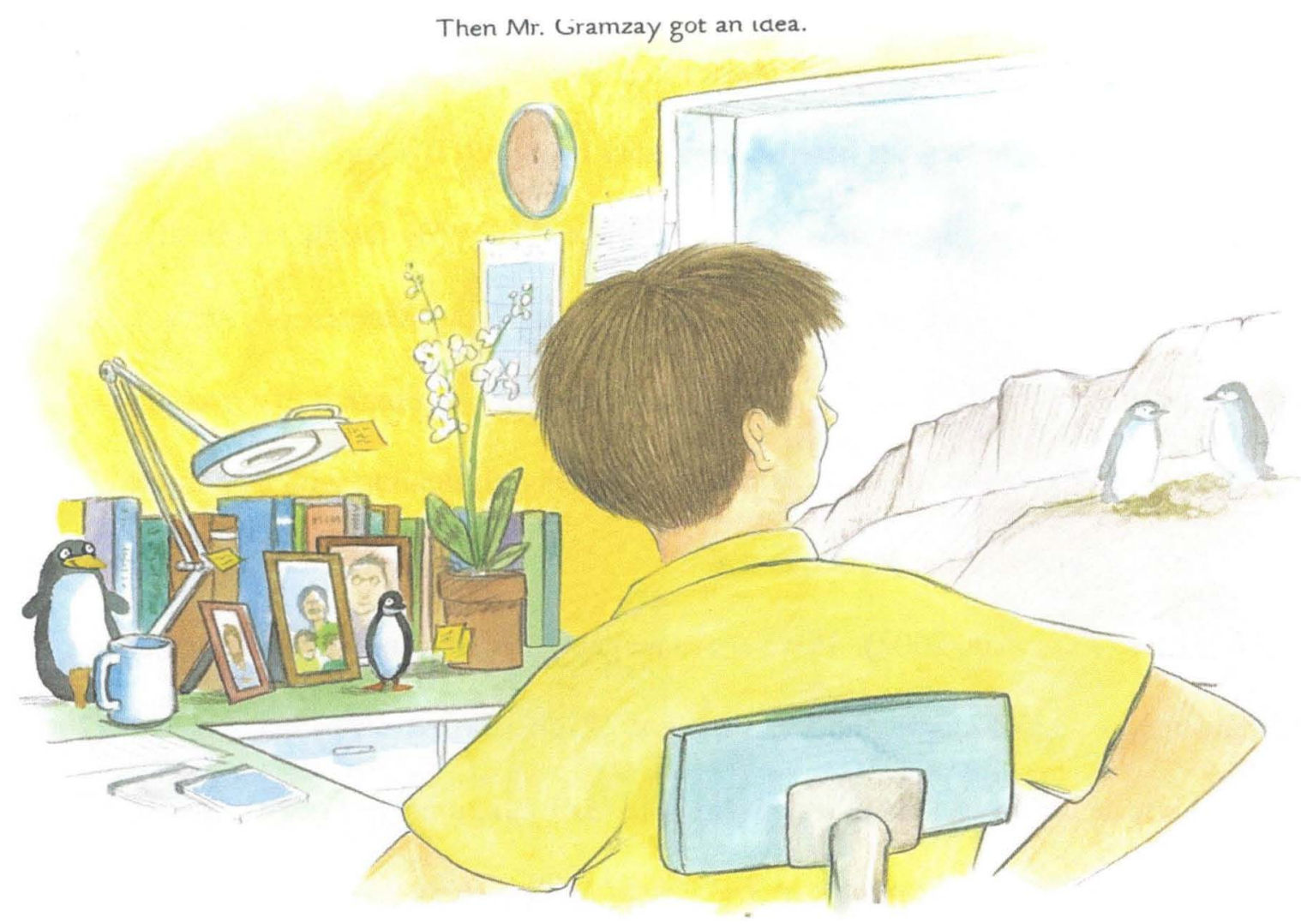

Queer analysis of Olivia and the Missing Toy

A queer critique of Olivia and the Missing Toy (Falconer, 2003) involved investigating sexuality as private and personal, the representation of difference, and a consideration of heteronormativity. Through a manifest content analysis it was discovered that Olivia and the Missing Toy (Falconer, 2003) could be deemed heteronormative for its exclusive representation of heterosexual relationships. A consideration of the illustrations and text using latent content analysis found the same to be true as Olivia's parent's 
heterosexual relationship is depicted as normal. In the next section a queer critique of this book will attempt to identify whether or not it seeks to challenge essentialism.

Olivia and the Missing Toy (Falconer, 2003) is a story about the misadventures of a headstrong, self-centered (piglet) girl named Olivia. Olivia lives with her mother, father, two brothers, a cat and a dog. While waiting for her mother to sew a new red soccer t-shirt, Olivia notices her "very best toy" is missing. After playing detective, Olivia discovers the family dog Perry chewing her favorite toy into pieces. From behind the newspaper, Olivia's father promises to replace her toy with "the very best toy in the whole world."

After performing a latent content analysis of this book, it was discovered that it could be interpreted as sexist due to the stereotypical ways in which its characters are represented. For instance, on some pages Olivia is illustrated pushing a stroller with her toy doll and her cat. In contrast, her brother Ian plays with a robot on one page and her younger brother William sits in front of a truck, a ball, and blocks on another page. Olivia's parents are also illustrated in stereotypical roles. The book begins with Olivia's mother dressed in a skirt and blouse with her hands folded in front of her saying "time to get up, sweetie pie. Remember you have soccer this morning." When Olivia requests that her mother make her a red soccer shirt, Olivia's mom obliges. Olivia's father, conversely, is dressed in a shirt and pants and appears relaxed sitting at the kitchen table with his face partially obscured by a newspaper. Food is being spilled while Olivia's mother is feeding the baby (see figure 7). 


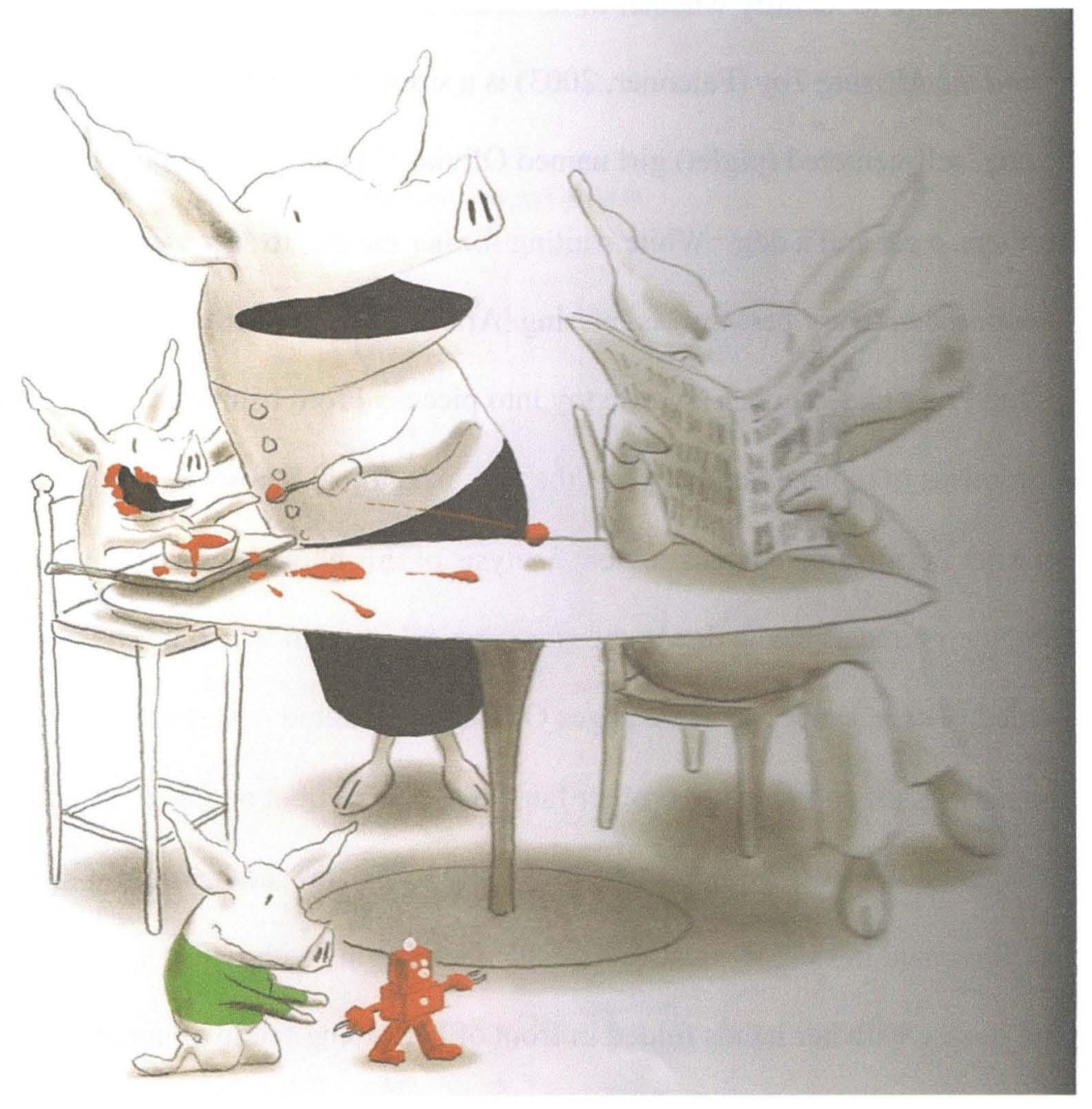

A strong message relayed in this book is that it is 'normal' for girls to want to play with dolls, and for woman to be maternal and care for children while fathers sit outside of the action. Furthermore, to be a girl or a woman is represented as meaning to have a relationship with a male and have a family. In addition to Olivia being shown in a traditional feminine role, playing with dolls and strollers, Olivia pursues soccer. While Olivia may have challenged some traditional gender roles by playing a sport, her male 
siblings wear traditionally male clothing and play with robots, balls, trucks, and blocks.

Furthermore, Olivia's father is either absent or detached.

A closer look at Olivia and the Missing Toy (Falconer, 2003) revealed that Falconer's attempts to portray a strong female character (in Olivia) have possibly undermined feminist readings by confusing self-esteem with entitlement. For instance, Olivia insists on having her mother make her a green soccer shirt and illustrations depict a great deal of impatience on the part of Olivia's mother while she obliges this whim.

Olivia's unnamed mother is portrayed as a "frenzied soccer mom" (Greenstone, 2008, 30) who is also an exhausted homemaker. According to scholars Douglas and Michaels to be a "decent mother, a woman has to devote her entire physical, psychological, emotional and intellectual being $24 / 7$ to her children" $(2004,4)$. On the one hand, this book has presented possibilities for upper middle class American girls. On the other hand, it amplifies the unfulfilled promises of feminist mothers who may balance professional success while continuing to singlehandedly fulfills traditional roles in the home (Greenstone, 2008).

When contemplating the interconnectedness of identity observed in Olivia and the Missing Toy (Falconer, 2003) it becomes evident that this book fails to incorporate text or illustrations that recognizes the link between gender, sexuality, class, age, ability, and body size. For instance, despite the fact that Olivia's is a family of pigs, none of the characters are portrayed as large, a characteristic that is normally attributed to pigs. The family is composed of personified pigs and therefore the ages of the characters are unclear; however, there are no signs that the parents are elderly or teenagers. Moreover, all characters are engaged in experiences that appear to coincide with their age. For instance, the youngest child is being fed, however the older children exhibit increased independence such as sitting 
up playing. In addition, no signs of representation of diversity of ability in the illustrations or text were evident. Through these omissions this book could be labeled sexist, heterosexist, classist, ageist, sizeist, and ableist.

\section{Conclusion}

The following chapter outlined and explained the findings for this preliminary research study investigating representation of diversity in children's literature. Findings revealed that a manifest content analysis is grossly inadequate to measure representation of diversity of sexuality in children's literature. Findings of a latent content analysis were compelling; however, the qualitative investigation of two specific titles provided the most analytical look at a sample of the books studied. These findings have informed subsequent chapters that will provide a thoughtful discussion and some recommendations to engage early childhood professionals in a discussion to promote careful book selection. 


\section{Chapter 5}

Discussion

In the literature review, previously published work was explored by examining different scholars' thoughts about books, representations of diversity in children's literature, discourse in early childhood education, and oppression. In this last chapter I have considered the research findings in an effort to determine if previously published work differs from the major findings of this study. In addition to stressing the significance of this study, theoretical and practical implications of this research project will also be discussed. Furthermore, throughout this discussion, limitations of my research have been highlighted, (such as how the process of deriving meaning from books is complex and is being considered by both children and adults.) Looking beyond the findings regarding representation of diversity in children's literature toward the dominant discourses has served to inform future recommendations. Before concluding this paper, the recommendations section has answered the final research question: how to best engage early childhood professionals in a dialogue that would serve to promote deliberate book selection.

\section{Major findings of this study}

Upon analysis of the findings of this research, it is clear that the major findings challenge those of previously published works. For instance, through the course of this research study it was discovered that a traditional feminist manifest content analysis counting method is inadequate, representation of diversity in children's literature is in often minimal, and alternate methods of analyzing children's literature are both available 
and effective. One theme presented throughout these findings is that what is not written or illustrated or what is not said is of great significance. For instance, literature studied for this last chapter indicated that in addition to studying books with a feminist poststructural and queer theory lens, it has been beneficial to explore beyond simply the books themselves.

\section{Previously Published Work}

This study's first research question regarding representation of gender, sexuality, race, class, ability, age, and body size required an investigation of the literature to determine what scholars have written about each category. The following section of the discussion chapter has identified the findings of this small research project and compared them to the studies examined in the literature review.

Representation of diversity of gender

Through the literature review it was discovered that scholars exploring issues of gender in children's literature have found that while there are marked improvements, male characters continue to dominate this field, clearly outnumbering females (Clark, 2002). Because the childcare settings examined for this study contained books published from 1947 to 2008, an improvement in publishing practices might not be apparent in this study's findings. This study concurred with Clark's research; of the books examined, $56.9 \%$ contained illustrations that could be deemed sexist while just $26.6 \%$ of text was insensitive to issues of gender. As it is typical to have a mix of old and new books on childcare bookshelves, I speculate that without deliberate books selection, having some sexist books is expected. 
Heterosexuality is present, taken for granted, and considered normative in everyday interactions within educational settings (Rothing, 2008). It is therefore not surprising that scholars (Clyde \& Lobban, 2001, Wolf, 1989) have recognized a lack of images or text about gay and lesbian characters in children's books. This literature review revealed that fewer than 80 gayfriendly children's titles published in the U.S. have reached the marketplace and subsequently go out of print quickly (Rowell, 2008). According to this research project, children's books depicting same sex relationships are almost never included in early childhood classrooms or collections. In fact, just two of the 109 books examined could be deemed gay-friendly. It is interesting to note that the two books were the same title, And Tango Makes Three, and that one of the books was located in a collection of ten books set aside in the early childhood educator's collection and the other was on loan from a parent. The obvious lack of representation of sexual diversity is telling, as it demonstrates not just exclusion, but also how dominant culture is perpetuated through children's literature.

\section{Representation of diversity of race}

Literature from the 1970s indicates that children's literature largely depicted middle class, Caucasian Americans (Bekkedall, 1973). Recent scholars have studied representations of diversity of race and found a growing awareness of issues of diversity and an increase in the amount of multicultural literature available to children (Agosto, Hughes-Hassell \& Gilmore-Clough, 2003, Fox, 2007, Rowell, 2007). Findings from this study concur with this research: almost half of the books analyzed reflected diversity of race in the illustrations. However, there is certainly room for improvement for books to be more reflective of Canadian urban multicultural communities. 
As indicated in the literature review, socio-economic class is presented as natural and inevitable in children's texts, which indicates classism and the perpetuation of a cycle of poverty (Gorski, 2008). By ignoring systems of oppression, Saltmarsh indicates that children's literature positions individuals to "recognize and take up their 'rightful' place in the social and economic order" $(2007,101)$. In this study's examination of class it was found that children's literature almost exclusively represented upper and middle classes. In fact, $95.4 \%$ of the books examined failed to represent society outside of these classes.

\section{Representation of diversity of ability}

Previously published works of scholars who have examined representation of ability in children's literature indicate that locating inclusive books is a challenge (Kaiser, 2007, Matthew \& Clow, 2007). This study corroborated these findings as just $87.2 \%$ of the books analyzed presented disabilities. Interestingly, because impaired eyesight was deemed a disability for this study, illustrations depicting eyeglasses accounted for most of the books that were categorized as reflective of diversity of ability. In the literature review of this research project I indicated that many books present inaccurate portrayals of disabled people as tragic victims who need charity and are defined by their disability (Kaiser, 2007). This finding was almost impossible to corroborate definitively, because too few books representing diversity of ability are readily available. Despite the fact that the inclusion of disabled characters in children's books is crucial (Matthew\& Clow, 2007), aside from individuals with eyeglasses, just one book representing a disability was found. One book, from the infant class, entitled My Up and Down and All Around Book 
(Pitzer, 2008), contained representations of ability. This photo board book depicts children with Down's Syndrome on every page. In contrast to the literature findings, the characters in My Up and Down and All Around Book (Pitzer, 2008) were not presented as victims but looked like happy children promoting opposites such as up and down and in and out.

Representation of diversity of age

According to literature reviewed, stereotypical portrayals of old age dominate children's literature (Zeece, 2007). This small study concurred, finding that just $12.8 \%$ of the books analyzed contained characters portrayed as older than 60 years of age. However, when older people were included in the books analyzed, they were typically grandparents participating in what the dominant discourse perceives as age appropriate activities. The literature review indicates that Fillmer (1983) found that children perceive elderly people as inactive, lonely, and nonproductive. With an increasing population of aging individuals in our society (Zeece, 2007), an accurate representation of age in children's literature is essential.

\section{Representation of diversity of body size}

As was stated in the literature review, prejudices against people with a large body size are "reinforced through literature" which propagates the belief that it is acceptable to discriminate against people based on their size (Wedwick, 1998). The mere fact that this study provided few opportunities to corroborate with other findings is telling. The lack of negative representation does not imply that the books analyzed were not sizeist in nature; in fact, the failure to include larger characters can be considered oppressive in and of itself. 
One of the goals of this research study is represented by the second research question; to determine if the counting method is adequate to examine representation of diversity in children's literature. In the literature review of this chapter, it was discovered that scholars (Babbie \& Benaquisto, 2002, Clark \& Fink, 2004, and Bekkedal, 1973) found the counting method adequate for this type of research. As will be elaborated upon later, a major finding of this study was that the counting method is in fact flawed. In this preliminary research project, the counting method yielded misleading findings rendering it impossible to accurately measure the frequency of heteronormativity.

\section{Alternate Methods of Exploring Representation}

Another aim of this research project was to determine if an alternate method of exploring representation of diversity in children's literature is possible. This study has used a feminist poststructural latent analysis and a queer theory analysis of children's literature. Therefore the insights produced in this study could not be gained from a traditional feminist perspective that makes exclusive use of counting methods. Furthermore, this study has used both poststructural and queer theory as a means of understanding the process by which gender relations become normalized thereby offering an opportunity to challenge beliefs about gender, sexuality (Allard \& Cooper, 1997) and more.

\section{Limitations}

\section{Limitations of manifest content analysis}


According to Babbie and Benaquisto (2002), manifest content analysis compromises the validity of a study since measuring text and illustration by counting the number of times a word appears might not provide accurate results for a research question. Statistically, this research method did provide some provocative findings; however, interestingly, the counting method failed to capture the underlying meaning of the texts, resulting in misleading findings. A manifest content analysis, which used a counting method to examine heteronormativity by tabulating terms meaning mother and father, grandmother and grandfather (and their synonyms), neglected various possibilities. The following section has outlined some examples of the limitations of using manifest a content analysis.

One particular instance in which inaccurate findings became evident was in the manifest content analysis of the book And Tango Makes Three (Parnell, Richardson, Cole, 2005). The repeated use of the terms mother and father (three times) and nineteen illustrations of male-female romantic relationships would normally have indicated that the book has heteronormative leanings. However, this book represented heterosexual and homosexual relationships and the book's focuses on the romantic relationship between two male penguins making efforts to start a family.

In contrast, Olivia and the Missing Toy (Falconer, 2000) included an illustration of a mother and father just once, and used the term mother and father on only one occasion. According to the manifest content analysis, And Tango Makes Three (Richardson, Parnell, Cole, 2005) appeared more heteronormative than Olivia and the Missing Toy (Falconer, 2000), which actually depicted heterosexuality exclusively. Another instance where a manifest content analysis was inadequate was in an analysis of 
Tikki Tikki Tembo (Mosel, Lent, 1968). According to the criteria for this analysis, this book was categorized as heteronormative because it contains illustrations of a male and female relationship on the cover of the book. As was determined through a latent content analysis, the text and illustrations inside the book indicate that the male and female on the cover of the book are not in a romantic relationship. Limitations of the manifest content analysis methodology became evident, indicating a need to go beyond the counting methodology.

\section{Limitations of latent content analysis}

Latent content analyses provided an in-depth valid interpretation of data; however, reliability was compromised due to the risk of inconsistency when coding and interpreting data (Babbie \& Benaquisto, 2002). Beyond reliability being compromised, another limitation is that the methodology identifies identity according to dominant discourse binaries. Furthermore the coding system categorizes these binaries such as male-female, fit-large, young-old, and heterosexual-homosexual in ways that are based on research, but nonetheless subjective. While the work of scholars was relied upon to inform the methodological choices of measurement, previously published work is potentially as subjective. Furthermore, exploring the underlying meaning of what is present and not present in the various texts has limitations. For example, the guiding questions of this study involved looking for stereotypes, as well as seeking to understand what is written and illustrated as well as what is not. Since latent content analysis had not been used to analyze books for representation of sexuality as private and personal, it failed to "challenge the notion of a static, essential, or natural identity" while acknowledging and celebrating difference (Slagle, 2003, 133). Although thick 
descriptives have been documented as part of the data collection for the latent content analysis, a queer critique had been neglected.

This preliminary research study therefore has been supplemented with a thorough investigation of two book titles using a queer lens to provide a critique that challenged the "essential nature of identities" (Slagle, 2003, 130). Throughout the course of this study, Slagle's model for queer critiques was used to inform a reading of And Tango Makes Three (Parnell, Richardson, Cole, 2005) and Olivia and the Missing Toy (Falconer, 2003). The aim of this critique was to compensate for the limitations of the latent content analysis and promote an understanding that oppression based on identity does not act independently, but instead intersects with many forms of discrimination (Davis, 2008).

\section{Limitations of queer analysis}

A limitation that was exposed during a queer analysis of And Tango Makes Three (Parnell, Richardson, Cole, 2005) and Olivia and the Missing Toy (Falconer, 2003) was that an exclusive consideration of the content of each book (looking at what is said and not said) failed to take into account information that lies beyond the text of the book. Reading beyond the text of the books for information about the author, other works by the author, and other studies performed regarding the authors and their work has resulted in intriguing supplementary findings. This next section emphasizes the limitations of exclusively considering the content of books by highlighting what is unsaid.

Beyond Olivia and the Missing Toy 
Research into the author of Olivia and the Missing Toy (Falconer, 2003) involved online searches that suggest that the author and illustrator of the book, Ian Falconer, is a homosexual. A bi-weekly newsmagazine focusing on gay life in America called "The Advocate" published an article titled He's a pig success: Illustrator Ian Falconer dazzles children with his best-selling books starring Olivia the pig (Giltz, 2003). A celebrity interview published in a national gay and lesbian magazine does not necessarily indicate that Ian Falconer is a homosexual. However, Bubon, who provides online recommendations for children's books, once posted that Ian Falconer is “a delightful gay man" (http://www.btwof.com/enews_extras/ImagesMBW8/MBW8_HTML.htm). Falconer's supposed sexuality led me to question why each of Falconer's children's books are heteronormative in nature. This is not to suggest that homosexual authors and illustrators should exclusively write books with homosexual themes that challenge oppression. However, based on the research findings of this small study, Olivia and the Missing Toy (Falconer, 2003) fails to challenge any norms about identity, and in fact consistently perpetuates heteronormativity.

Olivia the pig has been portrayed as a dramatic, precocious, confident protagonist. Evidently, Ian Falconer and the Olivia books he created are considered feminist in nature. Investigation beyond the book Olivia and the Missing Toy (Falconer, 2003) to what researchers have said about Falconer and the seven Olivia books he has written, indicate that beyond being popular, this series of books is supported by feminists. For example, the first Olivia book has a quote from Gloria Steinem on the cover exclaiming "At last, a pig with self esteem". Beyond And Tango Makes Three 
Of equal intrigue was what online research indicated about the story of the male penguins at the New York zoo featured in And Tango Makes Three (Parnell, Richardson, Cole, 2005). First, it was fascinating to find that the story, as it appears in the book, was only part of what Silo and Roy's story. In May 2005, The New York Times published an interview with one of the authors of And Tango Makes Three (Parnell, Richardson, Cole, 2005), Justin Richardson. Richardson has been quoted as having said he was inspired by a New York Times story about the penguins. According to Richardson, And Tango Makes Three (Parnell, Richardson, Cole, 2005) is a true story that has been told, "without editorializing" (Hallett, 2005). However, online research reveals that Roy and Silo separated soon after their story was published. According to Miller (2005), Roy and Silo "broke up" in the summer of 2004 when Silo "left" Roy for a female penguin named Scrappy. Although book publishing is a lengthy process, it is probable that the writers and illustrators of And Tango Makes Three (Parnell, Richardson, Cole, 2005) were aware of the change in Roy and Silo's relationship and chose to keep it out of the book. It is clear that by telling part of the story of Roy and Silo's six-year relationship that began in 1998, And Tango Makes Three (Parnell, Richardson, Cole, 2005) failed to challenge essentialism. Interestingly, the answer to one of the methodology questions about challenging essentialism has been found not through content analysis, but through an examination beyond what is printed in the book.

Examining research and contemplating an interview with one of the authors of this popular book have resulted in an increase of knowledge about the book And Tango Makes Three. Interesting to note is that although children's literature often anthropomorphizes animals, when writing And Tango Makes Three (Parnell, Richardson, 
Cole, 2005), Richardson was careful not to "put thoughts in the penguins' heads."

Richardson, however, has stated, "Tango is so cuddly... [making] it comfortable for parents to talk about these [same-sex] families" (Hallett, 2005). Furthermore, a close look at figure 5 shows these "cuddly" penguins looking at one another longingly in a way that appears very human. The issue was not whether or not Roy and Silo are homosexual; it was whether or not a story of animals in captivity should be deemed an adequate representation human sexual diversity.

According to Sklar, who is the spokesperson for the National Gay and Lesbian Task Force, looking to the behaviour of two penguins in captivity to answer questions about sexual orientation is not appropriate (Miller, 2005). Scientists have found that homosexual behaviour has been observed in animals both the wild and captivity (Smith, 2004). However, animals in captivity are not the same as animals in the wild. Often, due to a limited number of partners of the opposite sex, animals are often observed moving from homosexual to heterosexual relationships (Smith, 2004). Some argue that animals have been observed participating in homosexual activity, rendering said activity as "natural." New York Times journalist Smith (2004) has quoted Vasey, who cautions against drawing conclusions about humans based on animal behaviour noting that using animals to inform social policies or moral values makes no sense.

Further online research has led me to speculate about the intent of the authors, illustrators and publishers of And Tango Makes Three (Parnell, Richardson, Cole, 2005) and Olivia and the Missing Toy (Falconer, 2003). Richardson insists that this book is not a "piece of policy," but that children of gay and lesbian households might experience a "political impact" (Hallett, 2005). Also, authors Richardson and Parnell, who are partners, 
wanted to write a book "that treated the subject of same-sex couples that kids will adore... and beg their parents to read it again and again" (Hallett, 2005, http://www.usnews.com). Just as the dominant discourse may have influenced Falconer's writing and illustrating, publishing companies are not immune to the powerful force of dominant discourses. Marketing a book where male penguin partners break-up may lack appeal, and upon exploring beyond the content of the book, it was fascinating to ponder the influence of marketing to the gay community. According to Wikipedia, the lesbian, gay, bisexual and transgender (LGBT) market is large and influential. Companies are beginning to recognize that marketing to LGBT communities, estimated to be worth $\$ 660$ billion (2006) in disposable income, can prove prosperous. The oppressive power of the dominant discourse to influence authors, illustrators, marketers, publishers, and even early childhood educators are certainly worth considering.

The complexity of the meaning making process

Adults and children are active in meaning making processes and merely examining the surface content of books does not account for the ways in which teachers and children may interact with a text. According to Bekkedal, who used content analysis for her research, in order to explore children's literature in depth one needs to move beyond identifying characters and situations (1973). Although books themselves are inanimate static objects, the way in which people interact with books to make meaning is a complex process.

Although there is value in the analysis of various children's texts, it is evident that the way in which ECEs engage with literature is paramount. This research has ignored the reader and the individual or group being read, assuming that meaning making lies in 
the text itself. However, according to Patt and McBride (1992), when reading children's literature, teachers as well as children tend to add male pronouns to refer to the otherwise unknown gender of animals or people (Narahara, 1998). How books are read, whether and how they are discussed, and the children's and teacher's beliefs about reading, learning, and literature, all influence the experience of a child with a text. According to Eeds and Wells (1989), discussion is perhaps the most common space in which children can react to what is being read. Dialogue is an exceptional activity for encouraging students to form meaning from books. Variations in meanings of texts are dependent on the reader, what type of book is being discussed, and the experiences of the children being read to.

A key concept in both feminist poststructural theory and queer theory is language. According to Maynard (1995), these theoretical frameworks suggest that no firm knowledge or reality can exist beyond language that constructs it, and individuals are not homogeneous, but pluralistic and continually changing. Furthermore, according to Blaise (2005), individuals socially construct meaning through language, rendering it unfixed and open to change. In early childhood education settings, speech and action result in meaning making that is created and recreated as children take an active role in constructing identity (Blaise, 2005). Being cognisant of interactions between teachers, students, and texts is crucial (Pinar, 1998). Equally important is the discourse in early childhood education that informs these interactions.

\section{Practical and Theoretical Significance}

As was highlighted in the literature review, this study concurred with Saltmarsh's work, which asserts that children's literature serves to re-circulate discourses already 
present in the world which in turn "(re) shape" social realities $(2007,97)$. Pedagogical practices, ideologies, and procedures that define early childhood education are deeply embedded and as a result create discourses in the field of ECE. Practical implications of this study include a potential to inspire ECEs to influence a child's sense of identity by disrupting current normative conceptions.

While ECEs have an enormous responsibility to children and families, many lack the necessary education to support disrupting current normative conceptions. The purpose of teacher training is to ensure that teachers are knowledgeable about research in their field, and thus better prepared to translate theory into practice (Kent, 2004). However, according to Katz (1996), competency-based teacher education programs may overlook significant aspects of teaching. While ECE training programs are increasingly sensitive to issues of diversity, other issues such as gender, sexuality, age, and body size are often neglected. The neglect of these important categories is significant. The dominant discourse in early childhood education may fail to recognize identity as dynamic, relational, and interconnected. This chapter explores some of these issues in order to highlight the possible practical implications of this study.

According to Taguchi (2007), poststructuralist ECEs are moving away from $20^{\text {th }}$ century constructivist learning theory, and replacing these with theories of meaning making which are more cognisant of cultures, and contexts. Using a queer theory and poststructuralist approach, the dominant "truths" about femininity, masculinity, sexuality, and childhood can be dissolved (Taguchi, 2007, 277). Poststructural feminism is concerned with deconstructing dominant discourses, and advocating social change for women and other marginalized groups. As was discussed in the literature review, the 
principles of developmentally appropriate practice (DAP) are founded in developmental psychology literature from the $20^{\text {th }}$ century. These principles have informed the discourse of early childhood education (Blaise, 2005). However, the appropriateness of the DAP has been questioned due to its inability to address the unique nature of all children (McMullen, 2002). According to Blaise (2005), DAP privileges certain ways of knowing and being as "best practice" while ignoring diverse qualities of children and families. Shields (2007) advocates for a rejection of notions of "best practice," which do not acknowledge varying belief systems, values, attitudes, and opportunities. According to Shields, rejecting these notions would acknowledge these same systems (2007). Theoretically, this research project may provide a means to introduce the reconceptualist movement to early childhood educators.

As indicated in the literature review, the dominant discourse in ECE involves limitations that occur as a result of rigid binary structures (Butler, 1990). For instance, gender binaries require that there are two sexes, male and female, and the two genders balance in a way that encourages heterosexuality (Rothing, 2008). Homosexual and heterosexual is another binary that is normalized by implications that men appropriately execute their gender roles by having sex with women, and women by having sex with men. Michel Foucault wrote that "authorities exercising individual control function according to a double mode; that of binary divisions" such as boy and girl (1977: 199). The rigid binary system cultivates prejudice that has a harmful effect on all children, but particularly those who do not conform to society's conception of norms. Practically, one recommendation of this study is to engage early childhood professionals in dialogue that highlights the binaries of dominant discourse in early childhood education. Once the 
power of the dominant discourse in perpetuating the binaries is recognized, early childhood educators may overcome the rigidity of understanding identity as static and independent.

\section{Recommendations}

Although there may be some value in quantitative measures, clearly there exists a need to go beyond the numbers that are gained from a quantitative analysis. Based on the limitations regarding methodology, an obvious recommendation would be to dispute positivist methodologies, which involve systematic analyses of representative samples to produce empirical evidence. However, quantification has had several impacts in the world of children's books. According to Clark (2002), one of the first quantitative considerations of gender in children's literature by Weitzman et al. (1972) helped ameliorate publishing practices, and also led to the emergence of feminist publishing companies. In the case of this research project, quantitative data from this study could be effectively utilized to initiate dialogue with early childhood educators about the lack of representation of diversity in children's literature.

Robinson asserts that individual subjects are not stable, unified, or fixed, but dynamic (2006). This promising evidence supports change as possible, and lends hope to a time when ECEs will not instill, foster, or intensify heterosocialization (Sears, 1999). In order to provide children with the freedom to develop their personalities and character without of guilt or fear (Sears, 1999), it is necessary to challenge the norm. According to Tisdell, in order to ensure the status quo is not inadvertently maintained, a radical role change is required (1998). Sandlin (2005) concurs with this assertion, noting that education needs to be political, and in order to avoid reproducing inequalities, cultural 
assumptions should be critically analyzed (Sandlin, 2005). Therefore a major

recommendation of this research project is to present a workshop that addresses where to go from here and what how early childhood educators can change and grow.

The major recommendation of this chapter, to conduct a workshop, may help answer the final question of this research project: what is the best way to initiate dialogue with early childhood educators to promote deliberate book selection that considers diversity. This chapter has therefore highlighted some key components that could be used in a workshop format to achieve the aforementioned goal of promoting change in ECE book selection practices.

A workshop format may provide a platform to share research findings with early childhood professionals. The content analysis methods and findings can be used to highlight the power of the oppressive dominant discourse and the rigid binary systems within them. By first understanding the positionality of identity and the possibility of recognizing identity as a complex relationship comprised of identity and experiences, an increase appreciation of identity as interconnected may occur (Davis, 2008).

Bakhtin argues that recognition of dialogue is a dynamic process that considers past, current and future experiences. Bakhtin also promotes a celebration (queer carnival) of differences that goes beyond an increase in representation (Edmiston, 2007). According to Yin-Kun, binaries that contribute to essentializing normativity could be disrupted through queer carnival and heteroglossia (plurality of voices within our environments) bringing democratic experiences to children, parents and early childhood educators (2007). A carnival in an early childhood classroom defies ideas and truths through dialogue that releases the assumptions of the dominant culture. As with 
traditional carnivals, this approach would be a joyful and positive celebration.

Bakhtinian inspired dialogue for early childhood educators would promote participation in chronotope time space with consideration to plurality of voices within our environments (heteroglossia), and an encouragement to engage in dialogic interactions, with joyful and spontaneous introductions of power dynamics (carnival) (Shields, 2007). Through this approach we can provide opportunities and environments that encourage children to "actively negotiate, construct, and reconstruct identities" that challenge the dominant discourse (Edmiston, 2007). According to Edmiston (2007), Bakhtin believes that individuals should become the authors of their identities. Early childhood educators have a role in providing possibilities for children as they create and recreate the stories that make up their ever-changing perspectives and beliefs.

According to Taguchi $(2007,277)$, reconceptualizing ECE practices can be achieved using a feminist poststructural and queer theory approach which is aimed at dissolving the dominant 'truths' about femininity, masculinity, sexuality, childhood, and more (Blaise, 2005). Recommendations for this research project reflect the assertions of Blaise, who says that "understanding discourses and how they work in a classroom setting is a vital and necessary step" (Blaise, 2005, 17). An analysis of the deconstruction of binary opposites such as male-female, child-adult, and heterosexual-homosexual (Tisdell, 1998) will encourage early childhood educators to reflect about book selection. These recommendations go beyond calling for inclusion of books that represent diversity, as simply adding this representation is not adequate. Instead, these recommendations call for a shift in thinking that reflects the reconceptualist movement that presents a new image of a teacher and a child. 
This study has used the latent content analysis findings that investigate identity

binaries in attempts to provide a tool for initiating dialogue about the current lack of representation of diversity. However, this study does not aim to merely increase representation of diversity in children's literature. Identity is complex, dynamic and interconnected and one book about a particular person with disabilities may not speak to all children with a disability. Although we can aim to improve our current practices to represent more possibilities in children's literature, identity cannot be categorized. Therefore, this research invites early childhood professionals to recognize identity as complex, dynamic and interconnected and that meaning making in early childhood education is relational and based on our current and past experiences. The proposed recommendations are an invitation for early childhood educators to go beyond diversity as we currently know and really celebrate difference. This requires that professionals working with young children go beyond reading straight and together with children engage in critical dialogue about how identity is portrayed in books. If children coauthoring their identities are provided with options to challenge the dominant discourse diminishing sexism, heterosexism, ageism, ableism, sizeism, and racism could be possible.

\section{Conclusion}

In the first chapter, the importance of books was established and what scholars say about diversity was explored. Issues of oppression were introduced prior to stressing the importance of investigating that which is not said. In subsequent chapters, the study's methodology was outlined followed by findings indicating that representation of diversity in children's literature is minimal. Furthermore, it was acknowledged in the findings chapter 
that counting methods are severely inadequate and an exploration of a more sophisticated methodology utilizing a latent content analysis was proposed. Qualitative queer analysis of two books was conducted in the methodology section of the study and heteronormative leanings in these two books were exposed in the findings chapter. In this last chapter, the significance of this small study has been determined. For instance, despite many childcare settings boasting an inclusive philosophy that reflects a heterogeneous society, minimal representation of diversity exist on bookshelves in early childhood education classrooms.

Day asserts that exclusion "is one of the most insidious and painful forms of bias." Accordingly, omission and absence of representation is a form of "symbolic annihilation" (Day, 2000, xxiv). As early childhood educators, it is our responsibility to critically confront and discuss children's literature in order to "authenticate the experience of 'silenced' others” (Clark \& Fink, 2004). Books that aim to diminish oppression and potential internalized versions of oppression have the ability to alter the discourses within our ECE discipline. In order to ameliorate current practices, we must stop reading straight and initiate a dialogue regarding the deliberate selection of children's literature to reflect diversity so that finally, the silence can be broken and differences can be celebrated. 


\section{References}

Adams, M., Blumenfeld, W., Castaneda, R., Hackman, H., Peters, M., \& Zuniga, X (Eds.). (2000). Readings for diversity and social justice: An anthology on racism, anti-semitism, sexism, heterosexism, ableism, and classism. New York: Routledge.

Agosto, D., Hughes-Hassell, S., \& Gilmore-Clough, C. (2003). The all-white world of middle-school genre fiction: Surveying the field for multicultural protagonists. Children's Literature in Education, 34, 257-273.

Allard, A., \& Cooper, M. (1997, March). 'Too much talk, not enough action': An investigation of fourth year teacher education students' responses from issues of gender in teacher education curriculum. Paper presented at the Annual Meeting of the American Educational Research Association, Chicago, IL. (ERIC Document Reproduction Service No. ED408241)

American Library Association (2009, April). “And tango makes three” tops ALA's 2008 top ten list of most frequently challenged books. Retrieved May $7^{\text {th }}, 2009$ from

http://www.ala.org/ala/newspresscenter/news/pressreleases2009/april2009/nlw08 bbtopten.cfm

Anderson, J., \& Va. L. (1991). A letter to the king. Canada: Harper Collins.

Babbie, E, \& Benaquisto, L. (2002). Fundamentals of social research $\left(1^{\text {st }}\right.$ ed.).

Scarborough, ON, Canada: Thompson-Nelson.

Bekkedal, T. K. (1973). Content analysis of children's books. Library Trends, October, 109-126. 
Best Start expert panel on early learning. (2006). Early learning for every child today: A framework for Ontario early childhood settings. Retrieved June $3^{\text {rd }}$, 2009 from http://www.gov.on.ca/children/graphics/stel02_183342.pdf.

Blaise, M. (2005). Uncovering the heterosexual matrix. Playing it straight:

Uncovering gender discourses in the early childhood classroom. New York: Routledge.

Boynton, S. (1984). Opposites. New York: Little Simon.

Britzman, D. P. (1997). What is this thing called love? New discourses for understanding gay and lesbian youth. In S. de Castell \& M. Bryson (Eds.), Radical interventions: Identity, politics, and differences in educational praxis (pp.85-103). New York: State University of New York Press.

Bubon, L. (2006, May) It's Books to watch out for: For the kids: |Recommendations from Linda Bubon. Retrieved July 2009 from http://www.btwof.com/enews_extras/ ImagesMBW8/MBW8_HTML.html\#kids

Burke, L. C., \& Copenhaver, J. G. (2004). Animals as people in children's literature. Language Arts, 81, 205-213.

Burnett, N. (2008). The Delors report: A guide towards education for all. European Journal of Education, 43, 181-187.

Butler, J. (1980). Body/Power. In C. Gordon (Ed.), Power/Knowledge: Selected interviews and other writings 1972-1977 (pp. 55-62). New York: Pantheon. Butler, J. (1990). Gender trouble: Feminism and the subversion of identity. New York: Routledge.

Butler, J. (1993). Bodies that matter: On the discursive limits of "sex". New York: 
Routledge.

Butler, J. (2004). Bodies and power revisited. In D. Taylor \& K. Vintges (Eds.), Feminism and the final Foucault (pp. 183-194). Chicago: University of Illinois Press.

Cahill, B., \& Theilheimer, R. (1999). Stonewall in the housekeeping area: Gay and lesbian issues in the early childhood classroom. In W. Letts \& J. Sears (Eds.), Queering elementary education: Advancing the dialogue about sexualities and schooling (pp. 39-48). Lanham, MD: Rowan \& Littlefield Publishers, Inc.

Calixte, S. L., Johnson, J. L., and Motapanyane, J. M. (2005). Liberal, socialist, and radical feminism: An introduction to three theories about women's oppression and social change. In N. Mandell (Ed.), Feminist issues: Race, class, and sexuality (pp.1-34). Toronto: Pearson Prentice Hall.

Canadian Network for the Prevention of Elder Abuse (CNPEB, 2004). Retrieved on May 12, 2009 from http://www.cnpea.ca/

Chasnoff, D. (Director/ Producer), \&Cohen, H (Producer). (1996), It's elementary: Talking about gay issues in school [Motion picture]. San Francisco: Women's Educational Media.

Christelow, E. (1992). Don't wake up mamma! New York: Trumpet.

Clandinin, J. D., \& Connelly, M. F. (2000). Narrative inquiry: Experience and story in qualitative research. San Francisco: Jossey-Bass.

Clark, R., \& Fink, H. (2004). Picture this: A multicultural feminist analysis of picture books for children. Youth and Society, 36, 1-2,125.

Clark, R. (2002). Why all the counting? Feminist social science research on children's 
literature. Children's Literature in Education, 33, 285-295.

Clyde, A. L., \& Lobban, M. (2001). A door half open: Young people's access to fiction related to homosexuality. School Libraries Worldwide, 7, 17-30.

Cowley, J., \& Fuller, E. (1980). Mrs. Wishy-Washy. New York: Penguin Group.

Davis, K. (2008). Intersectionality as buzzword: A sociology of science perspective on what makes a feminist theory successful. Feminist Theory, 9:1, pp. 67-85.

Day, F. A., (2000). Lesbian and gay voices: An annotated bibliography and guide to literature for children and young adults. Westport, CT: Greenwood Press.

Edmiston, B. (2007). Forming ethical identities in early childhood play. London: Routledge-Taylor \& Francis.

Eeds, M., \& Wells, D. (1989). Grand conversations: An exploration of meaning construction in literature study groups. Research in the Teaching of English, 23, 4-29.

Falconer, I. (2000). Olivia. New York: Simon \& Schuster.

Falconer, I. (2003). Olivia ... and the missing toy. New York: Simon \& Schuster.

Fillmer, H. T. (1983). Children's descriptions of and attitudes toward the elderly. Paper presented at the Annual Meeting of the International Reading Association, Anaheim, CA. Abstract retrieved June 3rd, 2009 from Ebscohost

Foucault, M. (1977). Discipline and punish: The birth of the prison. New York: Random House.

Foucault, M. (1978). The history of sexuality: An introduction (Vol. 1).New York: Random House.

Foucault, M. (1980). Body/ Power. In C. Gordon (Ed.), Power/knowledge: Selected 
Interviews and other writings $1972-1977$ (pp. 55-62). New York: Pantheon.

Fox, R. (2007). One of the diverse hidden diversities in schools: Families with parents who are lesbian or gay. Childhood Education, 83, 277-281.

Gerde. J., \& Powell, D., (2009). Teacher education, book-reading practices, and children's language growth across one year of Head Start. Early Education and Development, 20, 211-237.

Giltz, M. (2003, October 14). He's a pig success: Illustrator Ian Falconer dazzles children with his best-selling books starring Olivia the pig. The Advocate. Retrieved July $3^{\text {rd }}, 2009$ from http://www.encyclopedia.com/The+Advocate+(The+national+gay+ A $\sim$ lesbian+newsmagazine)/publications.aspx?date $=200310$ \&pageNumber $=1$

Gorski, P. (2008). The myth of the "culture of poverty". Educational Leadership, 65, 3236.

Green, R. (2008, December). Early reading connects. Literacy Today, 57, 12.

Greenstone, D. (2008). The sow in the house: The unfulfilled promises of feminism in Ian Falconer's Olivia books. Children's Literature Association Quarterly, 33, 26-40.

Grieshaber, S., \& Cannella, G. S. (Eds.). (2001). Embracing identities in early childhood education: Diversity and possibilities. Early childhood education series. VT: Teachers College Press.

Hallett, V. (2005, May 5). Make way for gay penguins. US News. Retrieved May $30^{\text {th }}$, 2009 from http://www.usnews.com.usnews/culture/articles/050528/28penguins

Harms, T., Clifford, R., \& Cryer, D. (2005). Early Childhood Environment Rating Scale- 
Revised New York: Teachers College Press.

Haskins, F. (1992). Things I like about grandma. San Francisco: Children's Book Press.

Hindman, H. A., Connor, M. C., Jewkes, M. A., \& Morrison, J. F. (2008). Untangling the effects of shared book reading: Multiples factors and their associations with preschool literacy outcomes. Early Childhood Research Quarterly, 23, 330-350.

Janmohamed, Z., \& Campbell, R. (2009). Building bridges: Queer families in early childhood education.Retrieved June $14^{\text {th }}, 2009$ from http://www.oise.utoronto.ca/atkinson/Upcoming_Events/What_s_New!.html Johnson, C. (2009). Intersectionality, inequality \& maternal health. Paper presented at Annual Meeting of the Canadian Political Science Association, Carleton University, Ottawa, Ontario, May 2009. Retrieved on September 10, 2009 from http://docs.google.com/gview?a=v\&q=cache:ipXutH2zYKgJ:www.cpsaacsp.ca/papers2009/Johnson.pdf + intersectionality + over + positionality \&hl=en\&gl=c

Kaiser, C. E. (2007). Is your childhood literature collection disability-inclusive and current? Journal of Association for Library Services to Children With Special Needs, Winter, 5-12.

Katz, G. L. (1996). Child development knowledge and teacher preparation: Confronting assumptions. Early Childhood Research Quarterly, 11, 135-146. Keats, E. J. (1962). The snowy day. New York: Viking Press.

Keeling, K. K. \& Pollard, S. T. (Eds.). (2009). Critical approaches to food in children's literature. New York: Routledge. 
Kent, A. (2004). Improving teacher quality through professional development. Education, 124, 427-435.

Kirkpatrick, A. L., \& Feeney, C. B. (2005). A simple guide to SPSS for Windows for Version 12.0. Belmont, CA: Thomson Wadsworth.

Kosciw, J. (2004). The 2003 National School Climate Survey: The School-Related Experiences of Our Nation's Lesbian, Gay, Bisexual and Transgender Youth. New York: The Gay, Lesbian, and Straight Education Network. Retrieved June $14^{\text {th }}, 2009$ from http://www. glsen.org/binarydata/GLSEN_ATTACHMENTS/file/300-3.PDF

Lacasa, P., des Castillo, H., \& Garcia-Varela, B. A. (2005). A Bakhtinian approach to identity in the context of institutional practices. Culutre \& Psychology. 11, 287308.

Lester, N. A. (2007). (Un)Happily ever after: Fairy tale morals, moralities, and heterosexism in children's texts. Journal of Gay \& Lesbian Issues in Education, $4,55-74$.

Lesbian and Gay Parents Association (Producer). (1995). Both of my moms' names are Judy: Children of lesbians and gays speak out (Motion picture). (Available by mail from Lesbian and Gay Parents Association at 260 Tingley Street, San Francisco, CA 94112).

Marshall, E. (2004). Stripping for the wolf: Rethinking representations of gender in children's literature. Reading Research Quarterly, 39, 256-270.

Matthew, N., \& Clow, S. (2007). Putting disabled children in the picture: Promoting inclusive children's books and media. International Journal of Early Childhood, 
3965-78.

Maynard, M. (1995). Beyond the 'big three': The development of feminist theory in the 1990's. Women's History Review, 4, 259-281.

Miller, J. (2005, September 24). New love breaks up a 6-year relationship at the zoo. New York Times. Retrieved June $3^{\text {rd }}, 2009$ from http://www.nytimes.com/2005/09/24/ nyregion/24 penguins.html

Mosel, A., \& Lent, B. (1968). Tikki tikki tembo. New York: Henry Holt and Company. Mullen, M. C., \& Shield, J. (2004). Childhood and adolescent overweight: The health professional's guide to identification, treatment, and prevention. American Dietetic Association.

Narahara, M. (1998). Gender bias in children's picture books: A look at teacher's choice of literature (Report No. CS 216 342). Long Beach, California: University of California. (ERIC Document Reproduction Service No. ED419247)

Nuciforo, D. SR., \& Chin, M. (2009) Portrayal or betrayal: Representation of fat characters in children's literature. Retrieved June $15^{\text {th }}, 2009$ from http://www.google.ca/search?

$\mathrm{q}=$ Nuciforo + and + Chin\&btnG $=$ Search\&hl=en\&client=firefoxa\&rls=org.mozilla $\%$ 3Aen-US\%3Aofficial\&sa $=2$

O'Donnell, M. P., \& Wood, M. (1999). Becoming a reader: A developmental approach to reading instruction. $\left(2^{\text {nd }}\right.$ ed). MA: Allyn \& Bacon.

Pacini-Ketchabaw, V., \& Pence, A. (2005). Contextualizing the reconceptualist 
movement in Canadian early childhood education, In V. Pacini-Ketchabaw \& A. Pence (Eds.), Canadian early childhood education: Broadening and deepening discussions of quality (pp. 5-20). Ottawa, ON: Canadian Child Care Federation. Paterson, S. B., \& Lach, M. A. (1990). Gender stereotypes in children's books: Their prevalence and influence on cognitive and affective development. Gender \& Education, 2, 185-200.

Pinar, W. F. (Ed.). (1998). Introduction. In W. Pinar (Ed.), Queer theory in education. Mahwah, NJ: Lawrence Erlbaum Associates, Inc.

Pitzer, M. W. (2008). My up and down and all around book. United States: Woodbine House.

Rabinowitz, R. (2003). Fat characters in recent young adult fiction. Retrieved February $26^{\text {th }}, 2009$ from http://www.thefreelibrary.com/_/print/PrintArticle.aspx?id=108

Richardson, J., Parnell, P., \& Cole, H. (2005). And tango makes three. New York: Simon \& Schuster.

Robinson, K. (2002). Making the invisible visible: gay and lesbian issues in early childhood education. Contemporary Issues in Early Childhood, 3, 415-434.

Robinson, K. (2005). Queerying gender: Heteronormativity in early childhood education. Australian Journal of Early Childhood, 30, 19-28.

Robinson, K. (2006). Chapter 7: Gender performativity in early childhood education. In Diversity and difference in early childhood education (pp. 126-145). New York: Open University Press. 
Rodriguez, N. (2007). Queer theory and the discourse on queer(ing)

heterosexuality: Pedagogical considerations. In N. Rodriguez \& W. Pinar (Eds.), Queering straight teachers: Discourse and identity in education (pp. 277-307).

New York: Peter Lang.

Rothing, A. (2008). Homotolerance and heteronormativity in Norwegian

classrooms. Gender and Education, 20, 253-266.

Rowell, E. H. (2006, September). Missing! Picture books reflecting gay and lesbian families make the curriculum inclusive for all children. Journal of the National Association for the Education of Young Children. Retrieved July 13 ${ }^{\text {th }}, 2009$ from http://www. journal.naeyc.org/btj/200705/BTJMissing.asp

Rubin, S. A. (1995). Children who grow up with gay or lesbian parents: How are today's schools meeting this “invisible" group's needs? (Master's thesis, University of Wisconsin-Madison, 1995). (ERIC Document Reproduction Service No. ED386290)

Saltmarsh, L. (2007). Picturing economic childhoods: Agency, inevitability and social class in children's picture books. Journal of Early Childhood Literacy, 7, 95-113.

Sandlin, A. J. (2005). Andragogy and its discontents: An analysis of andragogy from three critical perspectives. PAACE Journal of Lifelong Learning, 14, 25-42.

Sears, J. (1999). Teaching queerly: Some elementary propositions. In W. Letts \& J. Sears (Eds.), Queering elementary education: Advancing the dialogue about sexualities and schooling (pp. 3-14). Lanham, MD: Rowan \& Littlefield Publishers, Inc. 
Shaffer, D. (Ed.). (2000). Social \& Personality Development. CA:

Wadsworth/Thomson Learning.

Shannon, D. (1998). No, David! New York: The Blue Sky Press.

Shannon, D. (1999). David Goes to School. New York: The Blue Sky Press.

Shields, C. (2007). Schooling with a difference. Bakhtin: Primer. New York: Peter Lang.

Slagle, A. (2003). Queer criticism and sexual normativity: The case of Pee-wee Herman. Journal of Homosexuality, 45, 129-146.

Smith, D. (2004, February 7). Central Park Zoo's gay penguins ignite debate. New York Times. Retrieved May 20 ${ }^{\text {th }}, 2009$ from http://www.sfgate.com/cgibin/article.cgi?f =/c/a /2004/02/07

Statistics Canada. Participation and activity limitation survey 2006: Tables. Ottawa: Statistics Canada, 2007 (Cat. No. 89-628-XIE - No. 003).

Su, W. (2008). Preschool children's perception of other children based on body size. Unpublished master's major research paper, Ryerson University of Toronto, Ontario, Canada.

Swadener, B. B., \& Cannella, G. (2007). Reconceptualizing early childhood education in North America: A brief introduction. Interaction, Winter, 25-26.

Taguchi, L. H. (2007). Deconstructing and transgressing the theory-practice dichotomy in early childhood education. Educational Philosophy and Theory, 39, 275-290.

Tankard, J. (2008). Me Hungry! MA: Candlewick Press.

Tisdell, J. E. (1998). Poststructural feminist pedagogies: The possibilities and 
limitations of feminist emancipatory adult learning theory and practice. Adult Education Quarterly, 48, 139-156.

Toshiko, S. (2000, August). Stereotypical role models in Western and non-Western children's literature. Paper presented at the International Conference for Global Conversations on Language and Literacy, Utrecht, The Netherlands. (ERIC Document Reproduction Service No. EC447502)

Trochim, M. K. W. (2001). The research methods knowledge base ( $2^{\text {nd }}$ ed.). Cincinnati, OH: Atomic Dog Publishing.

Wang, L. (2008). Weight discrimination: One size fits all remedy? Yale Law Journal, 117, 1900-1945.

Walker, J. (2008). Going for gold in 2010: An analysis of British Columbia's literacy goal. International Journal of Lifelong Education, 27, 463-482.

Wallen, E. N., \& Fraenkel. R. J. (2001). Educational research: A guide to the process $\left(2^{\text {nd }}\right.$ Ed.). Mahwah, NJ: Lawrence Erbaum Associates, Inc., Publishers.

Wedwick, L. (1998). The last accepted prejudice: Fat characters in series fiction. Studies in Popular Culture, 20.3. Retrieved June 17 $7^{\text {th }}, 2009$ from http://www. pcasacas.org / SPC/spcissues/20.3/ wedwick.htm

Weedon, C. (Ed.). (1997). Feminist practice and poststructuralist theory. USA: Blackwell Publishing.

Weitzman, J. L., Eifler, D., Hokada, E., \& Ross, C. (1972). Sex-role socialization in picture books for preschool children. The American Journal of Sociology, 77, 11251150.

Wharton, S. (2005). Invisible females, incapable males: Gender construction in a 
children's reading scheme. Language and Education, 5, 238-251.

Wikepedia. (n.d). LGBT marketing. Retrieved July $17^{\text {th }}, 2009$ from http://en.wikipedia.org/wiki/LGBT_marketing

Wise Brown, M., \& Hurd, C. (1947). Goodnight Moon. Mexico: HarperFestival.

Wolf, L. V. (1989). The gay family in literature for young people. Children's Literature World Health Organization. (2009). Obesity and overweight. Retrieved July $20^{\text {th }}, 2009$ in Education, 20, 51-58. from http://www.who.int/dietphysicalactivity/publications/facts/obesity/en/ Yin-Kun, C. (2007). Beyond soldiers in the closet: Creating queer carnival and aesthetic dimensions in the classroom. In N. Rodriguez \& W. Pinar (Eds.), Queering straight teachers: Discourse and identity in education (pp. 115-151). New York: Peter Lang.

Zeece, P. D., (2007). Grandparents and grand books. Early Childhood Education Journal, 35, 127-130. 


\section{Appendix A}

Ryerson University -Consent Agreement- Social Issues in Children's Literature in ECE
Settings You are being asked to allow my examination of the books available in bookshelves in your ECE setting for a research study. Before you give your consent, it is important that you read the following information and ask as many questions as necessary to be sure
you understand the research study.

Investigator: Tricia Dumais is a student currently enrolled in the Masters in Early Childhood Studies program at Ryerson University. As part of the requirements for this program, a major research assignment must be completed. This study is part of the research for the MECS program.

Purpose of the Study: This study is designed to explore social issues in the books available in ECE settings.

Description of the Study: This study will involve a thorough examination of the books available to the children in one classroom. This content analysis can occur outside of regular programming time. The ECE may choose to remain in the class if they choose. Furthermore, this study will utilize preexisting content analysis tools with modifications. A total of ten hours will be required for me to complete my examination of the books
available.

Risks or Discomforts: Participants may experience discomfort as a result of having me explore the books that they have selected for the children in their program. Should you begin to feel uncomfortable as a result of this study, you may discontinue participation,
either temporarily or permanently.

Benefits of the Study: This study has the potential to benefit the profession of early childhood education. The findings may inform practice of ECE to increase awareness about social issues in children's literature. This study may also serve to inform the practice of professionals working with young children as they gain an increased awareness of social issues in children's books.

Confidentiality: When I write about the study to share it with my supervisor and other Ryerson University faculty, I will write about the combined information that will be gathered. The results of this study may be published; however, the names of the early childhood professionals and other identifying information will be kept private.

Voluntary Nature of Participation: Participation in this study is voluntary. Your choice of whether or not to participate will not influence your future relations with Ryerson University or the ELC. If you decide to participate, you are free to withdraw your consent and to stop your participation at any time without penalty. Questions about the Study: If you have any questions about the research now, please ask. If you have questions later 
about the research, you may contact Tricia Dumais at 416-778-4050. If you have questions regarding your rights as a human subject and participant in this study, you may contact the Ryerson University Research Ethics Board for information.

Research Ethics Board, c/o Office of the Vice President, Research and Innovation Ryerson University, 350 Victoria Street, Toronto, ON M5B 2K3, 416-979-5042

Agreement: Your signature below indicates that you have read the information in this agreement and have had a chance to ask any questions you have about the study. Your signature also indicates that you agree to be in the study and have been told that you can change your mind and withdraw your consent to participate at any time. You have been given a copy of this agreement.

You have been told that by signing this consent agreement you are not giving up any of your legal rights.

Questions about the Study: If you have any questions about the research, you may contact:

Tricia Dumais

Student Researcher-

Master of Arts Candidate

Ryerson University

Early Childhood Studies

Telephone Number - (519 7449026

Email Address - pdumais@ryerson.ca

Name of Participant (please print)

Signature of Participant

Date 


\section{Appendix B}

Dear Early Childhood Educator,

I am an early childhood educator, currently enrolled in the Masters of Early Childhood Studies program at Ryerson University. As part of my graduation requirements, I am obliged to complete a major research project. I am interested in exploring social issues in children's literature available in early childhood education settings. I am seeking early childhood professional volunteers who would be willing to allow me to complete a content analysis of the books available to the children in their class. I would also request that the early childhood educator provide me with ten books read to children throughout the year so that I may complete an analysis of the text and illustrations of these books.

Should you be interested in allowing me access to the books in your class, I assure you that I will make every attempt to be unobtrusive. I will complete my research at times when children are not in the program, and am willing to negotiate a schedule that is most appropriate for participants who have volunteered. I propose a total of five hours to complete the content analysis of books in your class, over a series of visits.

Please rest assured that this research is anonymous. The names of the teachers, children, and daycare will not be used and will not be disclosed for the purpose of this
research.

Please feel free to contact me with questions or concerns you may have. I will also be in contact in coming days, though you may opt to express your interest in this project by informing your supervisor/ director. Thanking you in advance for your consideration.

Sincerely,

\section{Tricia Dumais}

BAH, Master of Arts Candidate, Ryerson University Early Childhood Studies pdumais@ryerson.ca

4167784050 


\section{Appendix C}

Good afternoon Sally, Thank you for distributing my research participant request. Two teams have communicated their willingness to have me investigate the books available to children in their class \& 10 books read throughout the year. I will set up dates next week.

Have a terrific day, tricia

Tricia Dumais

BAH, Master of Arts Candidate, Ryerson University Early Childhood Studies pdumais@,ryerson.ca

4167784050

Hi Sally,

The preschool team and infant/toddler team have agreed to allow me access to the books in their program. I would like to propose that I begin the content analysis of the books available to children in each program and 10 selected books in coming weeks. How is Tuesday, November 18th and Wednesday, November 19th at any time deemed appropriate by the class teams? I plan to be as unobtrusive as possible and working during nap, outdoor time, or before or after programs begin are all options I am considering. Please let me know what works.

Thank you so much for allowing me to complete my research at the ELC.

Tricia Dumais

BAH, Master of Arts Candidate, Ryerson University Early Childhood Studies pdumais@,ryerson.ca

4167784050 


\section{Appendix D}

Coding Sheet

Manifest content analysis exploring sexuality in children's literature

Narahara's look at gender will be revised to counts the number of times heterosexual and homosexual relationships were represented in text or in print. The manifest content analysis of this study will examine the following:

5) Frequency of illustrations representing members of the opposite sex who appear to be in a romantic relationship

6) Frequency of illustrations representing members of the same sex who appear to be in a romantic relationship

7) Frequency of text representing members of the opposite sex written about using language that implies a romantic relationship. For example, mother/father, mama/papa, husband/ wife, boyfriend/ girlfriend, grandmother/ grandfather or their synonyms

8) Frequency of text representing members of the opposite sex written about using language that implies a romantic relationship. For example gay, lesbian, boyfriend/ boyfriend, girlfriend/ girlfriend, father/ father, mama/mama, or their synonyms.

\section{Latent content analysis exploring representation of diversity of gender, sexuality, class,} size, ability, and age:

Gender diversity:

0 - no stereotypical representation of male or female character or unequal representation of males and females or no evidence of gender present 1 - illustrations and/ or text depict male and female characters in stereotypical ways (eg; gendered attire, gendered actions males =active, females =passive, more representation of males, use of terms such as fireman, male names or male nouns, pronouns, and possessive pronouns assigned more frequently than female names or female nouns, pronouns, and possessive pronouns) 
Sexuality diversity:

0 - no representation in illustrations and/ or text of same sex relationships or no relationships represented at all)

1 - sexual diversity (not heterosexual) evident in illustrations and/ or (e.g.; relationships of same sex partners evident)

Class diversity:

$0-$ no representation depicted in illustrations and/ or text

1- representation in illustrations and/ or of settings or characters in lower economic class other than upper-middle, or middle class (e.g.; apartment building, inner city dwellings, financial restrictions evident, etc)

Size diversity:

0 - no representation of larger body shapes in illustrations and/ or text

1- representation of characters that are overweight in illustrations and/ or text referring to a character using words such as overweight, fat, obese, or pudgy, plump, chubby, portly, stout, heavy, large, or big

Ability diversity:

0 - no representation of diverse abilities in illustrations and/ or text

1- representation in illustrations and/ or text of characters with varying abilities (hearing aid, mobility assistive devices, eye glasses, physically or cognitively disabled such as down syndrome, mental health issues such as depression, etc)

Representation of diversity age:

0 - no representation of characters who appear above the age of 50 or elderly

1- representation of elder characters in text or illustrations

In order to guide this analysis, the following questions have been borrowed from the work of Marshall (2004) and will be posed for each area of identity:

1) what stereotype or non-stereotypical traits arise

3) what is not said

4) what is not shown

\section{Queer theory qualitative analysis instrument:}

The model framework provided by Slagle will inform this section of the research project using a queer lens to investigate alternate methods to explore representation of 
diversity. Two books will be investigated with the following questions posed as an instrument to guide analysis.

1) Does this book represent sexuality as private and personal?

2) Does this book celebrate difference?

3) Does this book perpetuate heteronormativity by locating heterosexuality as "normal"?

4) Does this book challenge essentialism? 
Appendix E

\begin{tabular}{|c|c|c|c|c|c|}
\hline \# Of Book \& Title & Year & Publisher & Author & Site-group & Comments \\
\hline 1 Joy & 2001 & $\begin{array}{l}\text { Jump at the } \\
\text { Sun-Hyperion }\end{array}$ & $\begin{array}{l}\text { Joyce Carol Thomas } \\
\text { \& Pamela Johnson }\end{array}$ & $\mathrm{R}$ infants & $\begin{array}{l}\text { Mother \& son, } \\
\text { Black, big house }\end{array}$ \\
\hline $\begin{array}{l}2 \text { Peek-a-boo } \\
\text { Morning }\end{array}$ & 2002 & Putnam & Rachel Isadora & $\mathrm{R}$ infants & $\begin{array}{l}\text { g-ma \& g-pa, } \\
\text { hetero parents, } \\
\text { Black }\end{array}$ \\
\hline 3 Goodnight Moon & 1947 & Harper Festival & $\begin{array}{l}\text { Margaret Wise } \\
\text { Brown \& Clement } \\
\text { Hurd }\end{array}$ & $\mathrm{R}$ infants & $\begin{array}{l}\text { Gendered attire, } \\
\text { upper class, } \\
\text { ethnocentric } \\
\text { depictions } 3 \\
\text { bears... }\end{array}$ \\
\hline 4 Peek-a-boo Baby & 2001 & Little Simon & Margaret Miller & $\mathrm{R}$ infants & $\begin{array}{l}\text { Diversity of races } \\
\text { represented, faces } \\
\text { only }\end{array}$ \\
\hline $\begin{array}{l}5 \text { Andy Warhol's } \\
\text { Colours }\end{array}$ & 2007 & $\begin{array}{l}\text { Rubin } \\
\text { Chronicle } \\
\text { books }\end{array}$ & Susan Goldman & $\mathrm{R}$ infants & $\begin{array}{l}\text { "Big red dog } \\
\text { barks, bow wow, } \\
\text { wow...". }\end{array}$ \\
\hline $\begin{array}{l}\text { 6 Baa Baaa Black } \\
\text { Sheep }\end{array}$ & 2004 & $\begin{array}{l}\text { Child's Play } \\
\text { Int. Ltd }\end{array}$ & Annie Kubler & $\mathrm{R}$ infants & $\begin{array}{l}\text { Gendered attire \& } \\
\text { text } \\
\text { Culturally diverse }\end{array}$ \\
\hline $\begin{array}{l}7 \text { My Up \& Down \& } \\
\text { All Around Book }\end{array}$ & 2008 & $\begin{array}{l}\text { Woodbine } \\
\text { House }\end{array}$ & Marjorie W. Pitzer & $\mathrm{R}$ infants & $\begin{array}{l}\text { All down } \\
\text { syndrome \& } \\
\text { glasses book to } \\
\text { learn propositions } \\
\text { (in, out, ...) }\end{array}$ \\
\hline 8 My Dad & 1991 & Annick Press & $\begin{array}{l}\text { Debby Baily \& } \\
\text { Susan Huszar }\end{array}$ & $\mathrm{R}$ infants & $\begin{array}{l}\text { Photos, gendered } \\
\text { attire, diversity in } \\
\text { culture, glasses, } \\
\text { all dads }\end{array}$ \\
\hline 9 Baby Faces Sleep & 2004 & Scholastic & $\begin{array}{l}\text { Roberta Grobel } \\
\text { Intrater }\end{array}$ & $\mathrm{R}$ infants & $\begin{array}{l}\text { Photos, faces, } \\
\text { diverse culturally, } \\
2 \text { mothers nail } \\
\text { polish }\end{array}$ \\
\hline 10 Zoe's Windy Day & 1991 & Scholastic & Barbara Reid & $\mathrm{R}$ infants & $\begin{array}{l}\text { g-ma glasses, } \\
\text { white, middle } \\
\text { class, mail carrier } \\
\text { woman }\end{array}$ \\
\hline $\begin{array}{l}11 \text { Yum Yum Dim } \\
\text { Sum }\end{array}$ & 2003 & Tricycle Press & Amy Wilson Sanger & $\mathrm{R}$ infants & Food \\
\hline 12 Wheels on the Bus & 1988 & $\begin{array}{l}\text { Wickstrom } \\
\text { Crown }\end{array}$ & $\begin{array}{l}\text { Raffi \&Sylvie } \\
\text { Kantorovitz }\end{array}$ & $\mathrm{R}$ infants & $\begin{array}{l}\text { Gendered attired, } \\
\text { all white, glasses, } \\
\text { parents hetero }\end{array}$ \\
\hline $\begin{array}{l}13 \text { The Very Hungry } \\
\text { Caterpillar }\end{array}$ & 1969 & $\begin{array}{l}\text { Philomel } \\
\text { Books }\end{array}$ & Eric Carle & $\mathrm{R}$ infants & $\begin{array}{l}\text { Food \& caterpillar } \\
\text { (male) }\end{array}$ \\
\hline
\end{tabular}




\begin{tabular}{|c|c|c|c|c|c|}
\hline $\begin{array}{l}14 \text { Charlie Parker } \\
\text { Played Be Bop }\end{array}$ & 1992 & Scholastic & Chris Raschka & $\mathrm{R}$ infants & $\begin{array}{l}\text { Black man playing } \\
\text { sax, pigeons }\end{array}$ \\
\hline $\begin{array}{l}15 \text { Hand, Hand, } \\
\text { Fingers, Thumb }\end{array}$ & 1969 & Random House & $\begin{array}{l}\text { Al Perkins, Eric } \\
\text { Gurney }\end{array}$ & $\mathrm{R}$ infants & $\begin{array}{l}\text { Monkeys, gender } \\
\text { unclear }\end{array}$ \\
\hline $\begin{array}{l}16 \text { Brown Bear, } \\
\text { Brown Bear, What do } \\
\text { you See? }\end{array}$ & 1996 & $\begin{array}{l}\text { Henry Holt \& } \\
\text { Co. }\end{array}$ & $\begin{array}{l}\text { Bill Martin Jr \& } \\
\text { Eric Carle }\end{array}$ & $\mathrm{R}$ infants & $\begin{array}{l}\text { Diversity } \\
\text { represented in } \\
\text { children, teacher } \\
\text { glasses }\end{array}$ \\
\hline 17 Mrs Wishy Washy & 1980 & $\begin{array}{l}\text { The Wright } \\
\text { Group }\end{array}$ & $\begin{array}{l}\text { Joy Cowley, } \\
\text { Elizabeth Fuller }\end{array}$ & $\mathrm{R}$ infants & $\begin{array}{l}\text { Large woman, } \\
\text { gendered attire }\end{array}$ \\
\hline $\begin{array}{l}18 \text { Baby Fun } 5 \text { in the } \\
\text { Bed \& the Little one }\end{array}$ & 2003 & DK Publishing & Unknown & $\mathrm{R}$ infants & $\begin{array}{l}\text { Plush animals, } \\
\text { glasses, not } \\
\text { gendered }\end{array}$ \\
\hline 19 Everyone Poops & 1993 & $\begin{array}{l}\text { Kane/ Miller } \\
\text { Book } \\
\text { Publishers }\end{array}$ & Taro Gomi & $\mathrm{R}$ infants & $\begin{array}{l}\text { Gendered attire \& } \\
\text { actions. } \\
\text { Illustrations of } \\
\text { animals unclear. }\end{array}$ \\
\hline 20 The 3 Bears & 1991 & Harper Collins & Byron Barton & $\mathrm{R}$ infants & $\begin{array}{l}\text { Gendered \& } \\
\text { several hetero } \\
\text { illustrations \& } \\
\text { text. }\end{array}$ \\
\hline 21 Duck in the Truck & 1999 & Harper Collins & Jez Alborough & $\mathrm{R}$ infants & All males \\
\hline $\begin{array}{l}22 \text { More, More, } \\
\text { More, said the baby }\end{array}$ & 1990 & Harper Festival & Vera B. Williams & $\mathrm{R}$ infants & $\begin{array}{l}\text { Apartment, Black } \\
\text { g-ma, white child, } \\
\text { father \& child }\end{array}$ \\
\hline $\begin{array}{l}23 \text { The Book of } \\
\text { Outside }\end{array}$ & 2000 & Scholastic & $\begin{array}{l}\text { Ian Beck \& } \\
\text { Scholastic (text) }\end{array}$ & $\mathrm{R}$ infants & $\begin{array}{l}\text { Gender neutral -1 } \\
\text { child (long hair - } \\
\text { girl) }\end{array}$ \\
\hline 24 Baby Face Smile & 1997 & Scholastic & $\begin{array}{l}\text { Roberta Grobel } \\
\text { Intrater }\end{array}$ & $\mathrm{R}$ infants & Gender neutral \\
\hline 25 Opposites & 1984 & Little Simon & Sandra Boynton & $\mathrm{R}$ infants & $\begin{array}{l}\text { Various sizes } \\
\text { depicted -animals }\end{array}$ \\
\hline 26 Haiku Baby & 2008 & Random House & Betsy Snyder & $\mathrm{R}$ infants & $\begin{array}{l}\text { Chinese symbols, } \\
\text { animals }\end{array}$ \\
\hline $\begin{array}{l}27 \text { The Magic School } \\
\text { Bus- Plants seeds }\end{array}$ & 1995 & Scholastic & $\begin{array}{l}\text { Joanna Cole, } \\
\text { Patricia Relf, John } \\
\text { Spiers }\end{array}$ & R preschool & $\begin{array}{l}\text { Gendered, girls } \\
\text { more passive, } \\
\text { boys active role } \\
\text { Hetero } \\
\text { relationship, } \\
\text { glasses, some } \\
\text { diversity colour }\end{array}$ \\
\hline $\begin{array}{l}28 \text { How Georgina } \\
\text { Drove the Car Very } \\
\text { Carefully from } \\
\text { Boston to NY }\end{array}$ & 1989 & $\begin{array}{l}\text { Crown } \\
\text { Publishers Inc }\end{array}$ & $\begin{array}{l}\text { Lucy Bate Tamer } \\
\text { Taylor }\end{array}$ & R preschool & $\begin{array}{l}\text { All white, middle } \\
\text { class, hetero } \\
\text { relationships } \\
\text { often, gendered } \\
\text { attire }\end{array}$ \\
\hline
\end{tabular}




\begin{tabular}{|c|c|c|c|c|c|}
\hline $\begin{array}{l}29 \text { The New Baby } \\
\text { Calf }\end{array}$ & 1984 & Scholastic & $\begin{array}{l}\text { Barbara Reid, Edith } \\
\text { N Chase }\end{array}$ & R preschool & $\begin{array}{l}\text { Animals, family, } \\
\text { hetero, white }\end{array}$ \\
\hline 30 Find That Puppy & 1984 & $\begin{array}{l}\text { A Bantam } \\
\text { Little Rooster } \\
\text { Book }\end{array}$ & $\begin{array}{l}\text { Marcia Leonard, } \\
\text { Marie Chambliss }\end{array}$ & R preschool & $\begin{array}{l}\text { Hetero } \\
\text { illustrations, upper } \\
\text { class, statues } \\
\text { ethnocentric, jack } \\
\text { b nimble, humpty } \\
\text { dumpty }\end{array}$ \\
\hline 31 Kristy's Kite & 1988 & $\begin{array}{l}\text { An Albatross } \\
\text { Book }\end{array}$ & $\begin{array}{l}\text { Carol Curtis Stilz \& } \\
\text { Gwen Harrison }\end{array}$ & R preschool & $\begin{array}{l}\text { Hetero text \& } \\
\text { illustrations, } \\
\text { mother watching } \\
\text { from heaven, g-pa, } \\
\text { white, upper class }\end{array}$ \\
\hline 32 Franklin is Messy & 1994 & Kids Can Press & $\begin{array}{l}\text { Paulette Bourgeois } \\
\& \text { Brenda Clark }\end{array}$ & R preschool & $\begin{array}{l}\text { Gendered text \& } \\
\text { illustration, hetero } \\
\text { text, middle class } \\
\text { (sir bear save lady } \\
\text { beaver...) }\end{array}$ \\
\hline 33 Fox in Sox & 1965 & Random House & Dr Seuss & R preschool & $\begin{array}{l}\text { Sue in dress, more } \\
\text { male characters }\end{array}$ \\
\hline $\begin{array}{l}34 \text { Boom Chicka } \\
\text { Rock }\end{array}$ & 2004 & Chitwood & $\begin{array}{l}\text { Suzanne Tanner \& } \\
\text { John Archambault }\end{array}$ & R preschool & $\begin{array}{l}\text { Glasses, gender } \\
\text { unclear }\end{array}$ \\
\hline 35 Bear Snores On & 2002 & $\begin{array}{l}\text { Margaret K } \\
\text { McEldesny } \\
\text { books }\end{array}$ & $\begin{array}{l}\text { Karma Wilson \& } \\
\text { Jane Chapman }\end{array}$ & R preschool & $\begin{array}{l}\text { Gender of animals } \\
\text { uncertain except } \\
\text { bear- he }\end{array}$ \\
\hline $\begin{array}{l}36 \text { Johnny \& The } \\
\text { Birds }\end{array}$ & 1968 & $\begin{array}{l}\text { Rand McNally } \\
\& \text { Co }\end{array}$ & $\begin{array}{l}\text { Ian Munn \& } \\
\text { Elizabeth Webbe }\end{array}$ & R preschool & $\begin{array}{l}\text { Hetero } \\
\text { illustrations \& } \\
\text { text, gendered } \\
\text { attire \& actions } \\
\end{array}$ \\
\hline $\begin{array}{l}37 \text { My } \mathrm{ABC} \& \\
\text { Counting book }\end{array}$ & 1974 & $\begin{array}{l}\text { Award } \\
\text { Publications }\end{array}$ & Rene Cloke & R preschool & $\begin{array}{l}\text { Gendered actions } \\
\text { (g-skirts, } \\
\text { sedentary, b- } \\
\text { active), I for } \\
\text { Indian with } \\
\text { feathers }\end{array}$ \\
\hline $\begin{array}{l}38 \text { And Tango Makes } \\
3\end{array}$ & 2005 & $\begin{array}{l}\text { Simon \& } \\
\text { Schuster }\end{array}$ & $\begin{array}{l}\text { Justin Richardson, } \\
\text { Peter Parnell, \& } \\
\text { Henry Cole }\end{array}$ & R preschool & $\begin{array}{l}\text { Diversity colour, } \\
\text { sexuality } \\
\text { represented, } \\
\text { however: "little bit } \\
\text { different" others } \\
\text { homosexuality } \\
\end{array}$ \\
\hline 39 The Gruffalo & 1999 & $\begin{array}{l}\text { MacMillan's } \\
\text { Children's } \\
\text { Books } \\
\end{array}$ & Axel Scheffler & R preschool & $\begin{array}{l}\text { All characters } \\
\text { male except } \\
\text { mouse unclear }\end{array}$ \\
\hline
\end{tabular}




\begin{tabular}{|c|c|c|c|c|c|}
\hline $\begin{array}{l}40 \text { Don't Wake Up } \\
\text { Mama! }\end{array}$ & 1992 & Trumpet & Eileen Christefow & R preschool & $\begin{array}{l}\text { "fireman" x2, } \\
\text { monkeys, gender } \\
\text { unclear except for } \\
1 \text { in dress (all } \\
\text { male?) }\end{array}$ \\
\hline $\begin{array}{l}41 \text { Otto Goes to The } \\
\text { Beach }\end{array}$ & 2003 & $\begin{array}{l}\text { Little Brown \& } \\
\text { Co books }\end{array}$ & $\begin{array}{l}\text { Todd Parr \& Megan } \\
\text { Tingely }\end{array}$ & R preschool & $\begin{array}{l}1 \text { hetero } \\
\text { relationship } \\
\text { illustrated, home, } \\
\text { car }\end{array}$ \\
\hline $\begin{array}{l}42 \text { Go Away Big } \\
\text { Green Monster }\end{array}$ & 1992 & Scholastic & Ed Emberley & R preschool & $\begin{array}{l}\text { No depictions of } \\
\text { gender }\end{array}$ \\
\hline 43 Smiley Shark & 2003 & Tiger Tales & Ruth Galloway & R preschool & $\begin{array}{l}\text { "Fisherman's net" } \\
x 2 \text {, more male } \\
\text { characters }\end{array}$ \\
\hline $\begin{array}{l}44 \text { From Dr Seuss- } \\
\text { The Sneetches \& } \\
\text { Other Stories, What } \\
\text { Was I Scared of? }\end{array}$ & 1961 & Random House & Dr Seuss & R preschool & $\begin{array}{l}\text { Strange green } \\
\text { pants ok }\end{array}$ \\
\hline 45 Monkey Puzzle & 2000 & $\begin{array}{l}\text { Campbell } \\
\text { books }\end{array}$ & $\begin{array}{l}\text { Julia Donaldson \& } \\
\text { Axel Scheffler }\end{array}$ & R preschool & $\begin{array}{l}\text { Hetero } \\
\text { illustrations \& } \\
\text { text, baby looking } \\
\text { for mom -other } \\
\text { mums }\end{array}$ \\
\hline $\begin{array}{l}46 \text { The King The } \\
\text { Mice \& the Cheese }\end{array}$ & 1965 & Random House & $\begin{array}{l}\text { Nancy \& Eric } \\
\text { Gurney }\end{array}$ & R preschool & $\begin{array}{l}2 \text { females in } \\
65 \mathrm{pgs} \text {, gendered } \\
\text { text \& illus. } \\
\text { hetero } \\
\text { illustrations, } \\
\text { turban, } \$ \$\end{array}$ \\
\hline $\begin{array}{l}47 \text { Alicia Has A Bad } \\
\text { Day }\end{array}$ & 1994 & $\begin{array}{l}\text { Houghton } \\
\text { Mifflin Co. }\end{array}$ & Lisa Jahn Clough & $\mathrm{R}$ preschool & $\begin{array}{l}\text { Gendered attire, } \\
\text { Alicia \& dog only } \\
\text { characters, } \\
\text { glasses, white }\end{array}$ \\
\hline $\begin{array}{l}48 \text { Santa's Secret } \\
\text { Helper }\end{array}$ & 1990 & Scholastic & $\begin{array}{l}\text { Andrew Clements } \\
\text { \& Deborah Santini }\end{array}$ & R preschool & $\begin{array}{l}\text { Hetero } \\
\text { illustrations \& } \\
\text { text, prayers } \\
\end{array}$ \\
\hline 49 The Treasure & 1978 & Scholastic & Uri Shulevitz & R preschool & $\begin{array}{l}\text { Lower socio } \\
\text { economic class, } \\
\text { only men in tale }\end{array}$ \\
\hline $\begin{array}{l}50 \text { Simon Boom } \\
\text { Gives a Wedding }\end{array}$ & 1973 & $\begin{array}{l}\text { Four Winds } \\
\text { Press }\end{array}$ & $\begin{array}{l}\text { Yuri Suhl \& Margo } \\
\text { Zemach }\end{array}$ & $\mathrm{R}$ preschool & $\begin{array}{l}\text { Gendered, hetero } \\
\text { illustrations \& } \\
\text { text, upper class, } \\
\text { Jewish? }\end{array}$ \\
\hline 51 The Teeny Weeny & 2005 & Tiger Tales & Jack Tickle \& & R preschool & Gender unclear - \\
\hline
\end{tabular}




\begin{tabular}{|c|c|c|c|c|c|}
\hline Tadpole & & & Sheridan Cain & & animals \\
\hline 52 The Odd Egg & 2008 & $\begin{array}{l}\text { Macmillan } \\
\text { Children's } \\
\text { Books }\end{array}$ & Emily Gravett & R preschool & $\begin{array}{l}\text { Duck -he, all } \\
\text { birds had eggs }\end{array}$ \\
\hline $\begin{array}{l}53 \text { Tikki Tikki } \\
\text { Tambo }\end{array}$ & 1968 & $\begin{array}{l}\text { Henry Hot \& } \\
\text { Co. }\end{array}$ & $\begin{array}{l}\text { Arlene Mosel \& } \\
\text { Blair Lent }\end{array}$ & R preschool & $\begin{array}{l}\text { Heteronormative } \\
\text { illustration } 1^{\text {st }} \mathrm{pg} \text {. } \\
\text { gendered text \& } \\
\text { illustrations, } \\
\text { Chinese culture } \\
\text { represented }\end{array}$ \\
\hline $\begin{array}{l}54 \text { The Big Honey } \\
\text { Hunt }\end{array}$ & 1962 & $\begin{array}{l}\text { Beginner } \\
\text { Books }\end{array}$ & $\begin{array}{l}\text { Stanley \& Janice } \\
\text { Bernstein }\end{array}$ & R preschool & $\begin{array}{l}\text { Gendered attire. } \\
\text { Illustrations \& text } \\
\text { heteronormative. }\end{array}$ \\
\hline 55 The Me Book & 1989 & $\begin{array}{l}\text { Britannica } \\
\text { Discovery } \\
\text { Library }\end{array}$ & $\begin{array}{l}\text { Christine Timmins } \\
\& \text { John L. Daves }\end{array}$ & R preschool & $\begin{array}{l}\text { Gendered attire \& } \\
\text { actions. } \\
\text { Illustrations \& text } \\
\text { Heteronormative. } \\
\text { Many characters } \\
\text { Asian, Black, } \\
\text { glasses. }\end{array}$ \\
\hline $\begin{array}{l}56 \text { The Little } \\
\text { Duckling \& Their } \\
\text { friends }\end{array}$ & 1997 & Unknown & $\begin{array}{l}\text { Astrid Anand \& } \\
\text { Alex Glikin }\end{array}$ & R preschool & $\begin{array}{l}\text { Gendered attire on } \\
\text { maternal mother. } \\
\text { Glasses. }\end{array}$ \\
\hline $\begin{array}{l}57 \text { Mighty Machines } \\
\text { \& Other Farm } \\
\text { Machines }\end{array}$ & 1995 & DK Books & Claire Llewelly & R preschool & $\begin{array}{l}\text { Photos. Few of } \\
\text { females- sidebars, } \\
\text { cheerleaders = hay } \\
\text { bale weigh- } 5 \\
\text { tough football } \\
\text { players. }\end{array}$ \\
\hline 58 I Have to go Pee & 1989 & Annick Press & $\begin{array}{l}\text { Robert Munsch \& } \\
\text { Michael } \\
\text { Martchenko }\end{array}$ & $\mathrm{R}$ preschool & $\begin{array}{l}\text { Gendered attire. } \\
\text { White middle } \\
\text { class. } \\
\text { Heteronormative } \\
\text { illustrations \& } \\
\text { text. }\end{array}$ \\
\hline $\begin{array}{l}59 \text { Things I like } \\
\text { About Grandma }\end{array}$ & 1992 & $\begin{array}{l}\text { Children's } \\
\text { Book Press }\end{array}$ & Francis Haskins & R preschool & $\begin{array}{l}\text { Gendered attired, } \\
\text { challenges gender } \\
\text { roles "g-ma does } \\
\text { boy things too". } \\
\text { Heteronormative } \\
\text { illustrations. } \\
\text { Black, glasses, } \\
\text { church, \& social } \\
\text { security check. }\end{array}$ \\
\hline 60 The Juggling Pug & 2008 & $\begin{array}{l}\text { Arcade } \\
\text { Publishing }\end{array}$ & $\begin{array}{l}\text { Sean Byron \& Tom } \\
\text { Murphy }\end{array}$ & $\mathrm{R}$ preschool & $\begin{array}{l}\text { Gendered attire. } \\
\text { Heteronormative }\end{array}$ \\
\hline
\end{tabular}




\begin{tabular}{|c|c|c|c|c|c|}
\hline & & & & & $\begin{array}{l}\text { illustrations (even } \\
\text { dolls m-f). Mostly } \\
\text { White, middle } \\
\text { class (some } \\
\text { beige). }\end{array}$ \\
\hline 61 Me Hungry & 2008 & $\begin{array}{l}\text { Candlewick } \\
\text { Press }\end{array}$ & Jeremy Tankard & $\mathrm{R}$ preschool & $\begin{array}{l}\text { Gendered attire \& } \\
\text { actions (mother } \\
\text { with babies. Cave } \\
\text { people gender } \\
\text { unclear. }\end{array}$ \\
\hline $\begin{array}{l}62 \text { How to Catch a } \\
\text { Star }\end{array}$ & 2004 & Harper Collins & Oliver Jeffers & R preschool & $\begin{array}{l}\text { White middle } \\
\text { class, in home. } \\
\text { Seagull gender } \\
\text { unclear. }\end{array}$ \\
\hline 63 Wonderful Worms & 1992 & $\begin{array}{l}\text { The Millbrook } \\
\text { Press }\end{array}$ & $\begin{array}{l}\text { Linda Glaser \& } \\
\text { Loretta Krupinski }\end{array}$ & R preschool & $\begin{array}{l}\text { Male character. } \\
\text { White. }\end{array}$ \\
\hline $\begin{array}{l}64 \text { What Makes a } \\
\text { Shadow? }\end{array}$ & 1962 & $\begin{array}{l}\text { Let's-Read- } \\
\text { And-Find-Qut- } \\
\text { Science Books }\end{array}$ & $\begin{array}{l}\text { Clyde Robert Bulla } \\
\text { \& Adrienne Adams }\end{array}$ & R preschool & $\begin{array}{l}\text { Gendered attire \& } \\
\text { actions (father } \\
\text { paper, mother } \\
\text { cooking). White } \\
\text { middle class. } \\
\text { Heteronormative } \\
\text { illustrations. }\end{array}$ \\
\hline $\begin{array}{l}65 \text { Insect World- } 1^{\text {st }} \\
\text { Library Learning }\end{array}$ & 1988 & $\begin{array}{l}\text { Time Life } \\
\text { Books }\end{array}$ & Unknown & R preschool & Photos -insects. \\
\hline 66 Olivia & 2000 & $\begin{array}{l}\text { Athenaeum } \\
\text { Books (Simon } \\
\text { \& Schuster) }\end{array}$ & Ian Falconer & $\begin{array}{l}\text { M } \\
\text { Kindergarten }\end{array}$ & $\begin{array}{l}\text { Gendered attire \& } \\
\text { actions. } \\
\text { Heteronormative } \\
\text { illustrations \& } \\
\text { text. Upper- } \\
\text { middle class. }\end{array}$ \\
\hline $\begin{array}{l}67 \text { Olivia \& the } \\
\text { Missing Toy }\end{array}$ & 2003 & $\begin{array}{l}\text { Athenaeum } \\
\text { Books (Simon } \\
\text { \& Schuster) }\end{array}$ & Ian Falconer & $\begin{array}{l}\text { M } \\
\text { Kindergarten }\end{array}$ & $\begin{array}{l}\text { Gendered attire \& } \\
\text { actions. } \\
\text { Heteronormative } \\
\text { illustrations \& } \\
\text { text. }\end{array}$ \\
\hline $\begin{array}{l}68 \text { We Share } \\
\text { Everything }\end{array}$ & 1999 & Scholastic & $\begin{array}{l}\text { Robert Munsch \& } \\
\text { Michael } \\
\text { Martchenko }\end{array}$ & $\begin{array}{l}\text { M } \\
\text { Kindergarten }\end{array}$ & $\begin{array}{l}\text { Gendered attire \& } \\
\text { text "no other boy } \\
\text { in kindergarten } \\
\text { has pink pants". } \\
\text { Diversity } \\
\text { represented - } \\
\text { colour skin. }\end{array}$ \\
\hline $\begin{array}{l}69 \text { Chicka Chicka } \\
\text { Boom Boom }\end{array}$ & 1989 & Scholastic & $\begin{array}{l}\text { Bill Martin Jr., John } \\
\text { Archambeault \& } \\
\text { Lois Ehlert }\end{array}$ & $\begin{array}{l}\text { M } \\
\text { Kindergarten }\end{array}$ & $\begin{array}{l}\text { "Mamas \& papas" } \\
\text { in text, however, } \\
\text { not illustrated }\end{array}$ \\
\hline
\end{tabular}




\begin{tabular}{|c|c|c|c|c|c|}
\hline & & & & & $\begin{array}{l}\text { together. Gender } \\
\text { unclear-letters. }\end{array}$ \\
\hline $\begin{array}{l}70 \text { Chicka Chicka } \\
123\end{array}$ & 2004 & $\begin{array}{l}\text { Simon } \\
\text { Schuster }\end{array}$ & $\begin{array}{l}\text { Bill Martin Jr., } \\
\text { Michael Sampson \& } \\
\text { Lois Ehlert }\end{array}$ & $\begin{array}{l}\text { M } \\
\text { Kindergarten }\end{array}$ & $\begin{array}{l}\text { Gender of \#'s } \\
\text { neutral. "Brave } \\
\text { little \#,, he's not } \\
\text { shy". }\end{array}$ \\
\hline $\begin{array}{l}71 \text { David Goes to } \\
\text { School }\end{array}$ & 1999 & $\begin{array}{l}\text { The Blue Sky } \\
\text { Press } \\
\text { (Scholastic) }\end{array}$ & David Shannon & $\begin{array}{l}\mathrm{M} \\
\text { Kindergarten }\end{array}$ & $\begin{array}{l}\text { Gendered attire \& } \\
\text { actions. Large } \\
\text { (cook), glasses \& } \\
\text { diversity of colour } \\
\text { skin. Upper- } \\
\text { middle class. }\end{array}$ \\
\hline $\begin{array}{l}72 \text { Where the Wild } \\
\text { Things Are }\end{array}$ & 1963 & Harper \& Row & Maurice Sendak & $\begin{array}{l}\text { M } \\
\text { Kindergarten }\end{array}$ & $\begin{array}{l}\text { Max boy, wild } \\
\text { things appear to } \\
\text { be male? }\end{array}$ \\
\hline $\begin{array}{l}73 \text { Jillian Jiggs \& the } \\
\text { Secret Surprise }\end{array}$ & 1999 & Scholastic & Phoebe Gilman & $\begin{array}{l}\text { M } \\
\text { Kindergarten }\end{array}$ & $\begin{array}{l}\text { Gendered attire \& } \\
\text { actions. Mostly } \\
\text { white middle } \\
\text { class. } \\
\end{array}$ \\
\hline 74 The Way I Feel & 2000 & Scholastic & Janan Cain & $\begin{array}{l}\mathrm{M} \\
\text { Kindergarten }\end{array}$ & $\begin{array}{l}\text { Diversity of } \\
\text { culture. Gendered } \\
\text { attire \& actions. }\end{array}$ \\
\hline $\begin{array}{l}75 \text { A Letter to the } \\
\text { King }\end{array}$ & 1991 & Harper Collins & $\begin{array}{l}\text { James Anderson \& } \\
\text { Leong Va }\end{array}$ & $\begin{array}{l}\mathrm{M} \\
\text { Kindergarten }\end{array}$ & $\begin{array}{l}\text { Gendered } \\
\text { illustrations } \\
\text { (attire \& actions) } \\
\text { and text "if only I } \\
\text { had } \\
\text { son...daughters } \\
\text { only know how to } \\
\text { weep". }\end{array}$ \\
\hline 76 Plant & 1989 & $\begin{array}{l}\text { DK Eye } \\
\text { Witness Books }\end{array}$ & Dorling Kinderslay & $\begin{array}{l}\text { M } \\
\text { Kindergarten }\end{array}$ & $\begin{array}{l}1 \text { photo of old } \\
\text { tradition -kissing } \\
\text { under mistletoe }\end{array}$ \\
\hline $\begin{array}{l}77 \text { Canada From } A \text { to } \\
\mathrm{Z}\end{array}$ & 1999 & $\begin{array}{l}\text { Crabtree } \\
\text { Publishing }\end{array}$ & Bobbie Kalman & $\begin{array}{l}\mathrm{M} \\
\text { Kindergarten }\end{array}$ & $\begin{array}{l}1 \text { photo depicts } \\
\text { heterosexual } \\
\text { couple. All men } \\
\text { in parliament. } \\
\text { Lots of diversity } \\
\text { of culture. }\end{array}$ \\
\hline $\begin{array}{l}78 \text { I Spy Book of } \\
\text { Picture Riddles }\end{array}$ & 1992 & Scholastic & $\begin{array}{l}\text { Jean May Zollo \& } \\
\text { Carol Devine } \\
\text { Carson }\end{array}$ & $\begin{array}{l}\text { M } \\
\text { Kindergarten }\end{array}$ & Neutral \\
\hline 79 Farm & 1996 & $\begin{array}{l}\text { DK Eye } \\
\text { Witness Books }\end{array}$ & $\begin{array}{l}\text { Ned Hally \& Geoff } \\
\text { Brightling }\end{array}$ & $\begin{array}{l}\text { M } \\
\text { Kindergarten }\end{array}$ & $\begin{array}{l}\text { Mostly male white } \\
\text { farmers. } 1 \text { Black } \\
\text { woman stoop to }\end{array}$ \\
\hline
\end{tabular}




\begin{tabular}{|c|c|c|c|c|c|}
\hline & & & & & $\begin{array}{l}\text { press roots rice \& } \\
\text { woman baking } \\
\text { bread. }\end{array}$ \\
\hline 80 Jungle & 2004 & $\begin{array}{l}\text { DK Eye } \\
\text { Witness Books }\end{array}$ & $\begin{array}{l}\text { Theresa Greenway } \\
\& \text { Geoff Dam }\end{array}$ & $\begin{array}{l}\mathrm{M} \\
\text { Kindergarten }\end{array}$ & Neutral \\
\hline 81 Dinosaur & 2004 & $\begin{array}{l}\text { DK Eye } \\
\text { Witness Books }\end{array}$ & $\begin{array}{l}\text { David Norman \& } \\
\text { Angela Milner }\end{array}$ & $\begin{array}{l}\mathrm{M} \\
\text { Kindergarten }\end{array}$ & Neutral \\
\hline 82 Earth & 1994 & $\begin{array}{l}\text { DK Eye } \\
\text { Witness Books }\end{array}$ & Susanna Van Rose & $\begin{array}{l}\text { M } \\
\text { Kindergarten }\end{array}$ & Neutral \\
\hline 83 Canada in Colours & 2008 & Kids Can Press & Per-Henrick Gurth & $\begin{array}{l}\text { M } \\
\text { Kindergarten }\end{array}$ & $\begin{array}{l}\text { Some gendered } \\
\text { attire -animals } \\
\text { depicting some } \\
\text { diversity of gender } \\
\text { (clothing). }\end{array}$ \\
\hline $\begin{array}{l}84 \text { The Gift of the } \\
\text { Inuksuk }\end{array}$ & 2004 & Thomson Gale & $\begin{array}{l}\text { Mike Ulmer \& } \\
\text { Melanie Rose }\end{array}$ & $\begin{array}{l}\text { M } \\
\text { Kindergarten }\end{array}$ & $\begin{array}{l}\text { Only Inuit. } \\
\text { Females depicted } \\
\text { as powerful. } \\
\text { Illustration \& text } \\
\text { Heteronormative. }\end{array}$ \\
\hline $\begin{array}{l}85 \text { Totem Tale A Tall } \\
\text { Story From Alaska }\end{array}$ & 2006 & Paws IV & $\begin{array}{l}\text { Deb Vanesse \& } \\
\text { Erik Brooks }\end{array}$ & $\begin{array}{l}\text { M } \\
\text { Kindergarten }\end{array}$ & $\begin{array}{l}\text { Gender neutral- } \\
\text { animals }\end{array}$ \\
\hline 86 One Is Canada & 1999 & Harper Collins & $\begin{array}{l}\text { Maxine Trottier \& } \\
\text { Bill Slavin }\end{array}$ & $\begin{array}{l}\text { M } \\
\text { Kindergarten }\end{array}$ & $\begin{array}{l}\text { Diversity ability \& } \\
\text { culture. History } \\
\text { of Canada -Men } \\
\text { "sailors from } \\
\text { afar". }\end{array}$ \\
\hline 87 The Walking Stick & 1998 & Stoddart Kids & $\begin{array}{l}\text { Maxine Trottier \& } \\
\text { Annouchka Gravel } \\
\text { Galouchko }\end{array}$ & $\begin{array}{l}\text { M } \\
\text { Kindergarten }\end{array}$ & $\begin{array}{l}\text { Text \& } \\
\text { illustrations } \\
\text { Heteronormative. } \\
\text { Diversity Vietnam } \\
\text { Buddhist temple. } \\
\text { Mixed marriage = } \\
\text { yellow hair, } \\
\text { freckles. }\end{array}$ \\
\hline $\begin{array}{l}88 \text { From Seed to } \\
\text { Pumpkin }\end{array}$ & 2005 & Scholastic & $\begin{array}{l}\text { James Graham Hale } \\
\& \text { Wendy Pfeffer }\end{array}$ & $\begin{array}{l}\text { M toddler/ } \\
\text { preschool }\end{array}$ & $\begin{array}{l}\text { More (3) males } \\
\text { than female (1). } \\
\text { Diversity of } \\
\text { colour } \\
\text { represented. }\end{array}$ \\
\hline $\begin{array}{l}\text { 89 I Want to Be a } \\
\text { Firefighter }\end{array}$ & 1999 & Firefly books & Unknown & $\begin{array}{l}\text { M toddler/ } \\
\text { preschool }\end{array}$ & $\begin{array}{l}\text { Photos -mostly } \\
\text { males except } 1 \\
\text { female "must be } \\
\text { strong". All } \\
\text { white, able }\end{array}$ \\
\hline
\end{tabular}




\begin{tabular}{|c|c|c|c|c|c|}
\hline & & & & & bodied. \\
\hline $\begin{array}{l}90 \text { Tikki Tikki } \\
\text { Tembo }\end{array}$ & 1968 & $\begin{array}{l}\text { Henry Holt \& } \\
\text { Co. }\end{array}$ & $\begin{array}{l}\text { Arlene Mosel \& } \\
\text { Blair Lent }\end{array}$ & $\begin{array}{l}\text { M toddler/ } \\
\text { preschool }\end{array}$ & $\begin{array}{l}\text { Chinese. } \\
\text { Gendered attire \& } \\
\text { actions. } \\
\text { Heteronormative } \\
\text { illustrations \& } \\
\text { text. }\end{array}$ \\
\hline $\begin{array}{l}91 \text { The Tale of Little } \\
\text { Pig Robinson }\end{array}$ & 1988 & Penguin Group & $\begin{array}{l}\text { Retold (1930) by } \\
\text { Frederick Warna }\end{array}$ & $\begin{array}{l}\text { M toddler/ } \\
\text { preschool }\end{array}$ & $\begin{array}{l}\text { Ch. Book with } \\
\text { few illustrations } \\
\text { 123pgs, ripped } \\
\text { pages, missing } \\
\text { cover. Seaside } \\
\text { holiday. }\end{array}$ \\
\hline 92 Great Day For Up & 1974 & Random House & $\begin{array}{l}\text { Dr. Seuss \& } \\
\text { Quentin Blake }\end{array}$ & $\begin{array}{l}\text { M toddler/ } \\
\text { preschool }\end{array}$ & $\begin{array}{l}\text { More men than } \\
\text { women. All } \\
\text { white. Gendered } \\
\text { attire. }\end{array}$ \\
\hline $\begin{array}{l}93 \text { All Aboard Fire } \\
\text { Trucks }\end{array}$ & 1991 & $\begin{array}{l}\text { Grosset \& } \\
\text { Dunlap }\end{array}$ & $\begin{array}{l}\text { Teddy Slate \& Tom } \\
\text { LaPadula }\end{array}$ & $\begin{array}{l}\text { M toddler/ } \\
\text { preschool }\end{array}$ & $\begin{array}{l}\text { More men (1 } \\
\text { woman). White } \\
\text { only. About } \\
\text { equipment. }\end{array}$ \\
\hline $\begin{array}{l}94 \text { Load ‘em Up } \\
\text { Trucks }\end{array}$ & 1999 & Annick Press & $\begin{array}{l}\text { Chum McLeod \& } \\
\text { Debora Pearson }\end{array}$ & $\begin{array}{l}\text { M toddler/ } \\
\text { preschool }\end{array}$ & $\begin{array}{l}\text { More males. Girls } \\
\text { long hair. White } \\
\text { middle class } \\
\text { houses. }\end{array}$ \\
\hline $\begin{array}{l}95 \text { Now You See } \\
\text { Them, Now You } \\
\text { Don't }\end{array}$ & 1993 & Scholastic & $\begin{array}{l}\text { Fracois Caumartin } \\
\& \text { David Homel }\end{array}$ & $\begin{array}{l}\text { M toddler/ } \\
\text { preschool }\end{array}$ & $\begin{array}{l}\text { More males. } \\
\text { Female (1) } \\
\text { gendered attire, } \\
\text { makeup, jewels, } \\
\text { flowered hat. } \\
\text { White elite } \\
\text { hunting jungle. }\end{array}$ \\
\hline $\begin{array}{l}96 \text { No Dinosaurs in } \\
\text { the Park }\end{array}$ & 1990 & Scholastic & $\begin{array}{l}\text { Dorothy Joan Harris } \\
\text { \& Sylvie Daigneault }\end{array}$ & $\begin{array}{l}\text { M toddler/ } \\
\text { preschool }\end{array}$ & $\begin{array}{l}\text { White middle } \\
\text { class. Gendered } \\
\text { attire and actions. } \\
\text { More males. }\end{array}$ \\
\hline 97 Plain Noodles & 1989 & $\begin{array}{l}\text { Meadow } \\
\text { Mouse books }\end{array}$ & $\begin{array}{l}\text { Betty Waterson \& } \\
\text { Joanne Fitzgerald }\end{array}$ & $\begin{array}{l}\text { M toddler/ } \\
\text { preschool }\end{array}$ & $\begin{array}{l}\text { Gendered attire \& } \\
\text { actions. } \\
\text { Heteronormative } \\
\text { text \& } \\
\text { illustrations. }\end{array}$ \\
\hline $\begin{array}{l}98 \text { Celebrating } \\
\text { Mother's Day }\end{array}$ & 1999 & $\begin{array}{l}\text { Creative } \\
\text { Teaching Press }\end{array}$ & $\begin{array}{l}\text { Sandi Hill \& Susan } \\
\text { Banta }\end{array}$ & $\begin{array}{l}\text { M toddler/ } \\
\text { preschool }\end{array}$ & $\begin{array}{l}\text { Gendered attire. } \\
\text { Middle class. } \\
\text { Illustrations } \\
\text { Heteronormative }\end{array}$ \\
\hline
\end{tabular}




\begin{tabular}{|c|c|c|c|c|c|}
\hline $\begin{array}{l}99 \text { Pop-out \& Drive } \\
\text { Away Racers \& } \\
\text { Roadsters }\end{array}$ & 1996 & $\begin{array}{l}\text { Dorling } \\
\text { Kindersley }\end{array}$ & $\begin{array}{l}\text { Mary Atkinson, } \\
\text { Camela Decarie, } \\
\text { Richard Chasmore } \\
\text { \& Andy Crawford }\end{array}$ & $\begin{array}{l}\mathrm{M} \text { toddler/ } \\
\text { preschool }\end{array}$ & $\begin{array}{l}\text { All males. Mostly } \\
\text { white (some light } \\
\text { brown). }\end{array}$ \\
\hline $\begin{array}{l}100 \text { Where the Wild } \\
\text { Things Are }\end{array}$ & 1963 & Harper Collins & Maurice Sendak & $\begin{array}{l}\text { M toddler/ } \\
\text { preschool }\end{array}$ & $\begin{array}{l}\text { Max male. White } \\
\text { middle class. }\end{array}$ \\
\hline 101 The Peace Book & 2004 & $\begin{array}{l}\text { Little Brown } \\
\text { Co. }\end{array}$ & Todd Parr & $\begin{array}{l}\text { M toddler/ } \\
\text { preschool }\end{array}$ & $\begin{array}{l}\text { "Peace is being } \\
\text { different". Class } \\
\& \text { cultural } \\
\text { diversity } \\
\text { represented (face/ } \\
\text { head covering). }\end{array}$ \\
\hline $\begin{array}{l}102 \text { I'm Gonna Like } \\
\text { Me- Letting Off a } \\
\text { Little Self-Esteem }\end{array}$ & 2002 & $\begin{array}{l}\text { Joanna Colter } \\
\text { Books }\end{array}$ & Jamie Lee Curtis & $\begin{array}{l}\mathrm{M} \text { toddler/ } \\
\text { preschool }\end{array}$ & $\begin{array}{l}\text { Gendered attire. } \\
\text { Heteronormative } \\
\text { illustrations \& } \\
\text { text. } 1 \text { man with } \\
\text { jewellery \& nail } \\
\text { polish. }\end{array}$ \\
\hline $103 \mathrm{Mmmm}$, Cookies & 2000 & Scholastic & $\begin{array}{l}\text { Robert Munsch \& } \\
\text { Michael } \\
\text { Martchenko }\end{array}$ & $\begin{array}{l}\text { M toddler/ } \\
\text { preschool }\end{array}$ & $\begin{array}{l}\text { Gendered attire, } \\
\text { white middle } \\
\text { class, diversity of } \\
\text { culture } \\
\text { represented. } \\
\text { Heteronormative } \\
\text { illustration \& text. }\end{array}$ \\
\hline $\begin{array}{l}104 \text { Dancing With } \\
\text { Daddy }\end{array}$ & $\begin{array}{l}1999 \\
\text { pb2002 }\end{array}$ & $\begin{array}{l}\text { Whispering } \\
\text { Coyote }\end{array}$ & $\begin{array}{l}\text { Willy Welch \& Liza } \\
\text { Woodruff }\end{array}$ & $\begin{array}{l}\text { M toddler/ } \\
\text { preschool }\end{array}$ & $\begin{array}{l}\text { Gendered \& } \\
\text { Heteronormative } \\
\text { (all animals } \\
\text { dancing } \mathrm{m} / \mathrm{f} \text { ) } \\
\text { illustrations \& } \\
\text { text. White middle } \\
\text { class. }\end{array}$ \\
\hline $\begin{array}{l}105 \text { Something From } \\
\text { Nothing }\end{array}$ & 1992 & Scholastic & Phoebe Gilman & $\begin{array}{l}\text { M toddler/ } \\
\text { preschool }\end{array}$ & $\begin{array}{l}\text { Gender } \\
\text { stereotypes, also } \\
\text { males caring for } \\
\text { children, g-pa } \\
\text { sewing. Working } \\
\text { class Jewish. } \\
\text { Heteronormative } \\
\text { text \& } \\
\text { illustrations. } \\
\end{array}$ \\
\hline $\begin{array}{l}106 \text { Hanukkah A } \\
\text { Counting Book }\end{array}$ & 2001 & Scholastic & Emily Sper & $\begin{array}{l}\text { M toddler/ } \\
\text { preschool }\end{array}$ & $\begin{array}{l}\text { No people. } \\
\text { Candles, gelt, } \\
\text { dreidels. Text in } \\
\text { English, Hebrew } \\
\end{array}$ \\
\hline
\end{tabular}




\begin{tabular}{|c|c|c|c|c|c|}
\hline & & & & & \& Yiddish. \\
\hline $\begin{array}{l}107 \text { Chin Chiang the } \\
\text { Dragons Dance }\end{array}$ & $\begin{array}{l}1984 \\
\text { pb1992 }\end{array}$ & $\begin{array}{l}\text { Meadow } \\
\text { Mouse }\end{array}$ & Ian Wallace & $\begin{array}{l}\text { M toddler/ } \\
\text { preschool }\end{array}$ & $\begin{array}{l}\text { Gendered attire \& } \\
\text { actions. "Feet } \\
\text { (bones, corns, } \\
\text { knees) too old". } \\
\text { All Chinese. } \\
\text { Heteronormative } \\
\text { text \& } \\
\text { illustrations. }\end{array}$ \\
\hline $\begin{array}{l}108 \text { And Tango } \\
\text { Makes Three } \\
\text { And Tango Makes } 3 \\
\text { cont'd }\end{array}$ & 2005 & $\begin{array}{l}\text { Simon \& } \\
\text { Schuster }\end{array}$ & $\begin{array}{l}\text { Peter Parnell, Justin } \\
\text { Richardson \& Henri } \\
\text { Cole }\end{array}$ & $\begin{array}{l}\text { M toddler/ } \\
\text { preschool }\end{array}$ & $\begin{array}{l}\text { Diverse families } \\
\text { (colour, size, } \\
\text { sexuality) } \\
\text { Heteronormative } \\
\text { in text \& } \\
\text { illustrations } \\
\text { (showing mom \& } \\
\text { dad animal } \\
\text { families), right } \\
\text { boy \& girl } \\
\text { penguin....but Did } \\
\text { not label gay }\end{array}$ \\
\hline 109 Allison & 1997 & Mifflin Co. & Allen Say Houghton & $\begin{array}{l}\text { M toddler/ } \\
\text { preschool }\end{array}$ & $\begin{array}{l}\text { Gendered } \\
\text { illustration \& text } \\
\text { "a real boys } \\
\text { name". Upper } \\
\text { middle class. } \\
\text { Cultural diversity } \\
\text { daycare. } \\
\text { Adoption focus. } \\
\text { Heteronormativity } \\
\text { in illustrations \& } \\
\text { text }\end{array}$ \\
\hline
\end{tabular}

